Portland State University

PDXScholar

1990

\title{
The Relationship Between School Integration and Student Attitude Toward Residential Racial Integration
}

David Allen Johnson

Portland State University

Follow this and additional works at: https://pdxscholar.library.pdx.edu/open_access_etds

Part of the Social Policy Commons, and the Urban Studies Commons Let us know how access to this document benefits you.

Recommended Citation

Johnson, David Allen, "The Relationship Between School Integration and Student Attitude Toward Residential Racial Integration" (1990). Dissertations and Theses. Paper 1180.

https://doi.org/10.15760/etd.1179

This Dissertation is brought to you for free and open access. It has been accepted for inclusion in Dissertations and Theses by an authorized administrator of PDXScholar. Please contact us if we can make this document more accessible: pdxscholar@pdx.edu. 


\title{
THE RELATIONSHIP BETWEEN SCHOOL INTEGRATION AND STUDENT ATTITUDE TOWARD \\ RESIDENTIAL RACIAL INTEGRATION
}

by

DAVID A. JOHNSON

A dissertation submitted in partial fulfillment of the requirements for the degree of

\author{
DOCTOR OF PHILOSOPHY \\ in \\ URBAN STUDIES
}

Portland State University 1990 
TO THE OFFICE OF GRADUATE STUDIES:

The members of the Committee approve the dissertation of David A. Johnson presented May 4, 1990.

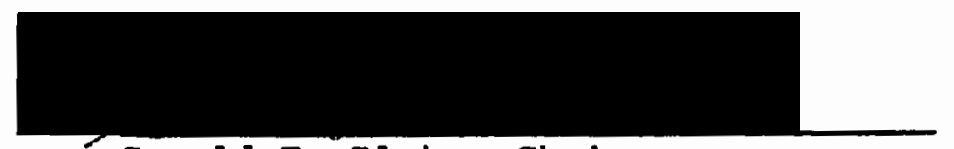

Gerald F. Blake, Chair

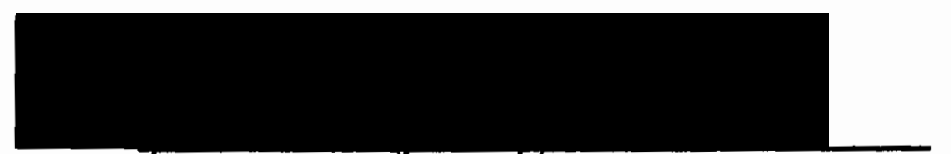

pames G. stzathmgh

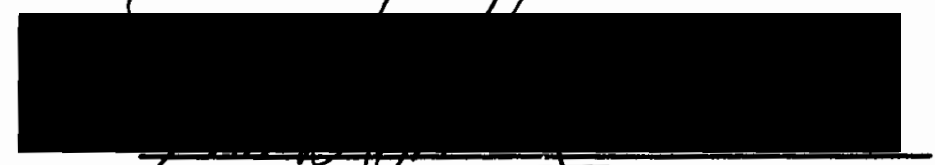

Nonad A. Tyutan

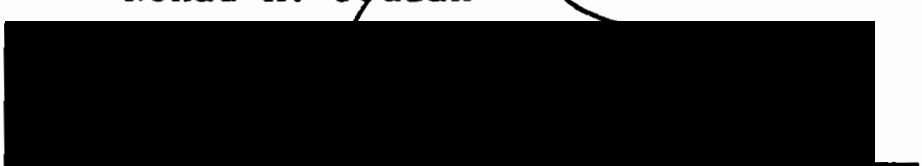

Barry F. Anderson

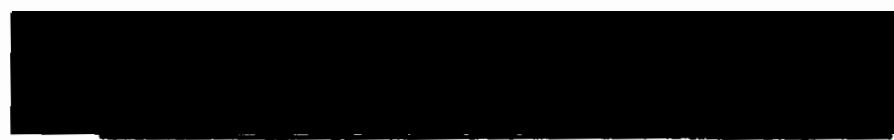

Darrell M. Milner

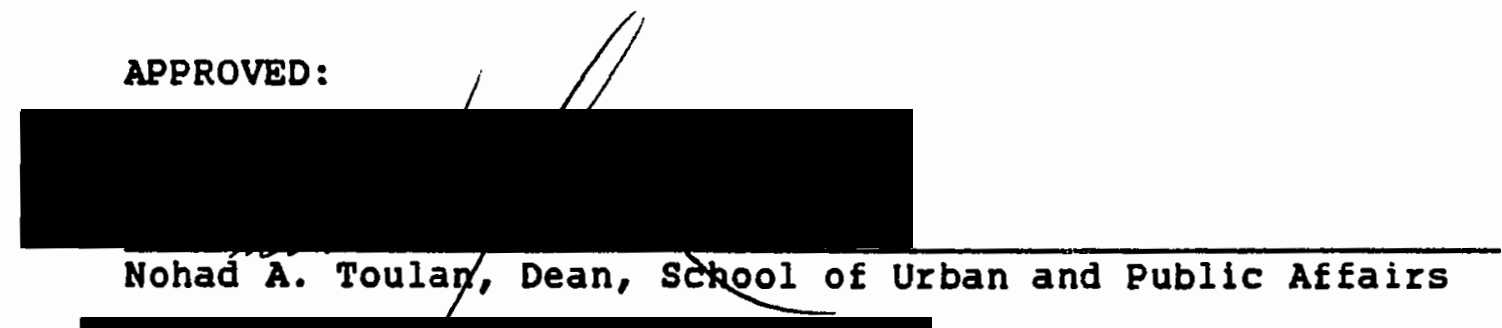

Nohad A. Toulay, Dean, sckgol of Urban and Public Affairs

C. William Savery, Interim 4 ice Provost for Graduate studies and Research 


\section{ACKNOWLEDGEMENTS}

Major life accomplishments involve more than individual effort. This dissertation is no exception. The completion of this project is the result of support and influence from a company of many. Ut special mention is the Maurie clark Fellowship. The fellowship allowed me critical time away from work to complete this project. Such support is invaluable to an urban university where doctorial candidates have to balance work and academic demands.

On a personal level, my brother Bill set the academic standard, my mother set the expectation, and my rather encouraged me to go for it. My wife, sue, deserves a chapter of acknowledgement for her support and assistance. she spent hours typing drafts and years giving me quiet support and encouragement. She was sensitive to the emotional burden of a project "in process" and her commitment to my work was as strong, if not stronger, than my own. Finally, I want to thank my father and mother-inlaw, Milt and Janet, for being interested in my work. Their abllity to vicariously share in the accomplishments of family is remarkable.

On a professional level, 1 owe thanks to so many people, it would be impossible to name them all. There are, however, as I complete this work, a tew that come to mind. Ray Rist gave me the initial opportunity to conduct research 
in the area of school integration. That opportunity started me down a path that resulted in this study. Gerry Hlake guided and encouraged me as I embarked upon and conducted the research tor this dissertation. The other members of my dissertation committee: Dr. Toulan, Dr. Strathman, and Dr. Anderson, all made significant contributions to this study. Jim strathman was particularly helpful with the statistical analysis. Dr. Toulan's critique of the premise and conclusion of earlier drafts enhanced the presentation of this research. Dr. Anderson was always there with helptul suggestions about how to strengtnen the research design and analysis.

Finally, there are a number of people who were helptul on both a personal and protessional level. Dr. Joseph Gallegos has, and continues to be, a friend and protessional mentor. His friendship and computer were indispensable. The Commulty Action Team Board and statt were supportive of my commitment to this project. Their professional respect and recognicion of my work were necessary for the completion of this dissertation. Penny Burton deserves many thanks for her hours of word processing and willingness to work when needed.

In closing, I should also like to thank bod tor the opportunity to live and study in his creation. 
TABLE OF CONTENTS

CHAPEER

PAGE

I SCHOOL INTEGRATION AND

SOCIETAL INTEGRATION . . . . . . . . . . . 1

Public schooling and Social

Change: Changing Future

Generations. . . . . . . . . . . 2

School Integration As a Means of

Bringing About Societal Integration

Through Changing students. . . . . . 3

School Integration As a Means of

Bringing About Long Term Residential

Integration. . . . . . . . . . . 5

I I REVIEW OF THE LITERATURE ON THE RELATIONSHIP BETWEEN SCHOOL INTEGRATION AND RESIDENTIAL

RACIAL INTEGRATION. . . . . . . . . . . 26

Residential Integration Trends . . . . 20

School Integration and

Residential Integration. . . . . . . 22

Measuring the school

Integration Experience . . . . . . . . 27

Amount of Interracial contact

and Attitudes Toward Residential

Integration

The Onset of the School Integration Experience and Attitudes Toward

Residential Integration

Particlpation in Integrated Extracurricular Activities and Attitudes Toward Residential

Integration 
The Relationship Between School Integration and Attitudes Toward Residential Racial Integration: Consideration of Antecedent Variables

II RESEARCH SETTING AND METHODOLOGY. . . . . . 35

Research Setting . . . . . . . . 35

Survey Instrument:

Variables and Measures. . . . . 38

Classroom Racial Composition scale

Onset of School Integration Experience scale

Involvement in Integrated

Extracurricular Activities Scale

Behavioral Attitude scale

Antecedent Variables: Race, Parents' Educational Background, and Neighborhood Racial Composition

Data Collection and Sample. . . . . . . 46

IV DATA ANALYSIS AND RESULTS. . . . . . . . 51

Descriptive statistics. . . . . . 53

Classroom Racial Composition

Onset of School Integration Experience

Involvement in Racially Integrated

Extracurricular Activities

Behavioral Attitude Toward Residential Racial Integration

Multiple Regression Analysis . . . . . . 63

The Onset of school Integration and student Attitude Toward Residential Racial Integration. . . . . . . . . . 78 
Other Aspects of School Integration

Experience and student Attitude Toward

Residential Raclal Integration. . . . . . 86

The Relationship Between school

Integration and Attitude Toward

Residential Racial Integration:

differential Results for Minority

and Majority Groups . . . . . . . . . . 90

School Integration Policy and

Societal Integration. . . . . . . . . . . 94

Student Att 1 tude Toward Residential

Racial Integration and subsequent

Behavlor. . . . . . . . . . . . . 95

REFERENCES. . . . . . . . . . . . . . . . 96

APPENDICES

A SURVEY QUESTIONNAIRE . . . . . . . . . .164

B CHRONOLOGY OF DATA COLLECTION. . . . .168

C SURVEY COVER SHEET . . . . . . . . . .113

D CORRESPONDENCE WITH SCHOOL DISTRICT. . .115

E RAW DATA . . . . . . . . . . . .126 


\section{LIST OF TABLES}

\section{TABLE}

PAGE

I Racial segregation in portland public Schools: Percent Hlack E'nrollment in selected Schools. . . . . . . . 11

Ii Racial Segregation in portland Public Schools: Percent Black Enrollment in Selected schools. . . . . . . . 15

II Assignment of Black students to Schools

Outside Black Neighborhoods by

School Neighbornood Area . . . . . 16

IV Black kesidential Segregation: Comparison

ot Census Tracks $197 \%-1980 . . . . .23$

$V$ Racial Composition of Portland public Schools. . . . . . . . . . 39

VI Sample Population Composition. . . . . . 51

VI Sample Population Compared to sample Universe . . . . . . . . . . 52

VII Classroom Racial Composition . . . . . . 56

IX Classroom Racial composition: f'requency

Distribution by Race... . . . . 58

$x$ onset of school integration. . . . . . 60 
XI Involvement in Integrated Extracurricular Activities . . . . . . . . 61

XI Behavioral Attitude Toward Residential racial Integration. . . . . . . 63

XII Behavioral Attitude roward Residential

Racial Integration: Frequency

Distribution by Race . . . . . . 65

XIV Multiple Regression Analysis of Variation

in Attitude Toward Residential

Integration: Stepwise Regression. . 67

XV Multiple Regression Analysis of Variation

in Attitude Toward Residential

Integration: Partial

Correlations and Beta Weights. . . 68

XVI MuLi-Collinearity Among Predictors:

Tolerance coefficients . . . . . 72

XVII Integration Effects of Predictors on

Behavioral Attitude. . . . . . . . 74

XVIII OSI and BA Correlation summary . . . . . . 80

XIX Minority Enrollment Trends:

Eercent Minority Enrollment. . . . . 84

XX Comparison of White and Non-White Mean

NRC, CRC, and BA scores........ 91 


\section{LIST OF FIGURES}

FIGURE $\quad$ PAGE

1 OSI X BA bY RA ................. . 74

2 NRC X BA bY SCH . . . . . . . . . . . . . 75 
AN ABSTRACT OF THE DISSERTATION OF David Allen Johnson for the Doctor of Philosophy in Urban Studies presented

May 4, 1990

Title: The Relationship Between school Integration and

student Attitude Toward Residential Racial

Integration.

APPROVED BY THE MEMBERS OF THE DISSERTATION COMMITTEE:
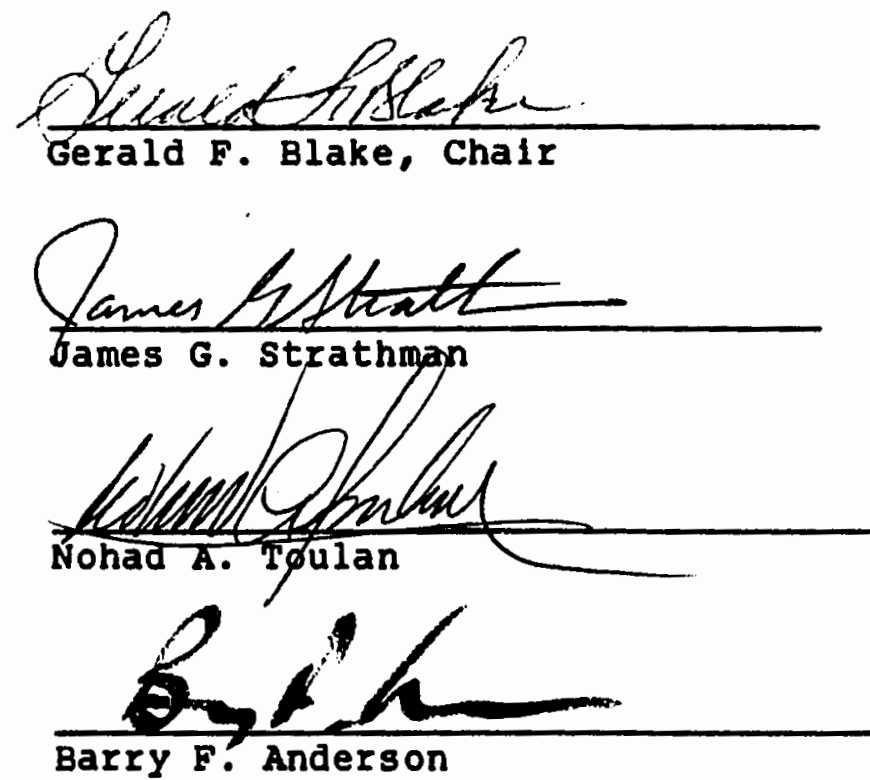

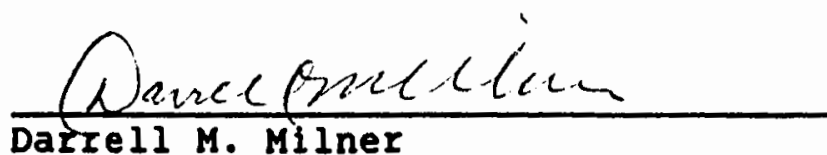

A generation has passed since the landmark, 1954, Supreme Court ruling in Brown V. Board of Education, Topeka, kansas. As a result of this decision, school integration 
became established as normative policy in school districts across the United states (Rist, 1979). However, atter thirty-six years, the impact of school integration, particularly in the area of societal integration, remains unclear foreeley, 1989; Hawley, 1983; Hochschlld, 1984; Prager, et.al., 1986). This dissertation examines the relationship between school integration experiences and attitudes towards residential racial integration.

High school seniors in the portland oregon public School bistrict comprised the data source tor this stuay. A sample of 315 students were surveyed. school integration experience was measured in three ways: 1) classroom racial composition (CRC), 2) onset of school integration experiences (USI), and 3) participation in racially integrated extracurricular activities (EA). Behavioral attitude toward residential racial integration (BA) was measured by responses to a hypothetical residential choice question. Potentially influential antecedent variabies of race (RA), neighborhood racial composition (NRC), and parents' educational background ( $\mathrm{HEH}$ ), were also measured.

The results of a multiple regression analysis indicate the following model: $B A=a+b_{2}(K A)+b_{2}(S C H)+b_{3}($ USI $)+$ $b_{4}(N R C)+b_{s}(P E B)+e$. For this model $R=.618$ and $R^{2}=$ .382 (significant at. $y 0$ level). Of the three hypothesized school integration variables, only the onset of school integration experience demonstrated a significant, positive, 
association with behavioral attitude toward residential raclal integration. One un-hypothesized school integration variable, school racial composition ( $\mathrm{SCH})$, was negatively associated with BA. I'he higher the minority racial composition of the school, the lower the preference for a racially integrated neighborhood.

Two significant (.05 level) functional relationships were identified. The relationship between neighborhood racial composition and behavioral attitude toward residential racial integration was dependent on being in a school with a high Non-white composition. Also, the relationship between the onset of school integration experience and attitude toward residential racial integration was contingent on race. The relationship between OSI and BA was significant for whites and insignificant for Non-whites.

During the 1980s, Portland's School integration policy shifted from that of forcing interracial contact at the early grade levels to emphasizing voluntary integration. This shitt in policy has resulted in increased racial isolation in some elementary schools. The present study indicates that a reduction in interracial contact at the early grade levels will weaken the relationship between school integration and positive attitudes toward societal integration in Portland, Oregon. 
CHAPTER I

SCHOOL INTEGRATION AND SOCIETAL INTEGRATION

A generation has passed since the 1954 landmark Supreme Court ruling in Brown $v$. Board of Education, Topeka, Kansas. During the past thirty-five years, the effect of this decision has been visited upon many U.S. urban communities In the form of school desegregation. By 1976, the peak of the school integration movement, 615 public school districts were implementing raclal integration plans and policies (Rist 1979) After thirty-five years the impact of school integration on societal integration, e.g., employment, leisure activity, and residential living, remains unclear (Greeley 1980; Hawley 1983; Hochschild 1984):

Thirty years after the Brown decision, in the
wake of this flow and ebb of integrationist
idealism, what are the contours of the American
racial terrain? We have evidence to
claims ranging from "racism is as virulent and
destructive as ever" to "race is no longer a
useful category." (Hochschild 1984: 18)

This dissertation examines school integration in the context of public schooling's social change function. That is to say, is school integration related to differences in attitudes toward societal integration? More specifically, is there a relationship between school integration 
experiences and attitudes toward residential racial integration? This question needs to be addressed in order to evaluate the social change function of school integration as it pertains to societal integration.

PUBLIC SCHOOLING AND SOKIAL CHANGE:

CHANGING FUTURE GENGRATIONS

Since its inception, public education has been viewed as a means to bring about social change. Katz (1971) notes that the mission of early public school movements was that of changing the intellectual and moral capabilities of poor chlldren:

Established in 1805 , the New York Free school
society stated its purpose as "extending the means
of education to such poor children as do not
belong to, or are not provided for by, any
religious society." The society offered poor
children training in the rudiments of literacy and
in morality as it unabashedly tried " to
counteract the disadvantages resulting from the
situation of their parents." (Katz 197l: 7 )

The contention that public education is a viable mechanism for bringing about social change remained strong throughout its development in this country. Thomas Jefferson believed that universal public education would "raise the mass of people to the high ground of moral responsibility," and Horace Mann advocated that public education would "eradicate ignorance and prejudice" (Hochschild 1984: xiii). 
Today, public schools consume close to one-tenth of the U.S. gross national product (Hochschild 1984). Although the ablitty of public schools to bring about social change has come increasingly under attack, they are still looked upon as a means to effect positive social change in American society. Whether the goal is to reduce drug abuse, raise Black achievement, or to compete more effectively with the Japanese, public education is singled out as the primary means to achieve social outcomes. These social outcomes are the children or students who have gone through the public schooling experlence and then exhibit the desired attitudes and behavior.

SCHOOL INTEGRATION AS A MEANS OF BRINGING ABOUT SOCIETAL IATEGRATION THROUGH CHANGING STUDENTS

No other event dramatizes more the extent to which public education has been used to bring about social change than the landmark supreme Court decision in Brown v. Board of Education of Topeka, Kansas. In that case the court unanimously concluded that racial segregation in public school systems was unconstitutional because it denied Black chlldren equal protection under the law by depriving them of equal educational opportunity:

We come then to the question presented: Does segregation of children in public school solely on the basis of race, even though the physical facilities and other tangible factors may be equal, deprive the children of the minority group 
of equal educational opportunities? We believe that it does. (Brown v. Board of Education 1954: 483)

The Supreme Court's ruling in Brown v. Board of Education Illuminated the role of public schools in determining social outcomes. By concluding that public schools were responsible for perpetuating unequal opportunity between Black and white children, the court clearly implied that the same public schools could bring about equal opportunity through school integration. The Court thus made public schools the keystone of modern efforts to bring about racial equality.

As school integration policies became more prevalent in the 1960s, racial integration in public schools became viewed not only as a means to bring about equal educational opportunity for Blacks but also as a way to bring about an integrated society. This was vividly demonstrated by the conclusions of the Kerner commission report on racial disorder in the sixties. After concluding that America was "moving toward two societies, one black, one white, separate and unequal," the comnission cited school integration as a primary means of bringing about a more racially integrated society:

We support integration as the priority education strategy because it is essential to the future of American society. We have seen in this last summer'g disorders the consequences of racial isolation, at all levels, and of attitudes toward race, on both sides, produced by three centuries 
of myth, ignorance and blas. It is Indispensable that opportunities for interaction between the races be expanded. The problems of this soclety will not be solved unless and until our children are brought Into a common encounter and are encouraged to forge a new and more viable design of life. (Report of the National Advisory Commission on Civil Disorders 1968: 438)

Thus, in addition to achleving equal educational opportunity, the policy of school integration became viewed as a means to reduce raclal isolation "at all levels" of society. In order to accomplish this goal, school integration would have to affect the attitudes and behavior of students. This dissertation will examine the relationship between school integration experiences and student attitudes toward residential racial integration.

\section{SCHOOL INTEGRATION AS A MEANS OF BRINGING ABOUT LONG TERM RESIDENTIAL INTEGRATION}

There is a lack of research on the relationship between school integration and socletal integration (Braddock 1985). studies of school integration have primarily focused on student achievement and interracial conflict (Weinberg 1970; Mosteller and Moynihan 1972; st. John 1975; Crain, Manard, and Navot 1982). Consequently, the impact of school integration on housing integration is unclear (orfield $1978)$.

The lack of research on the relationship between school desegregation and societal integration srems in large part 
from a lack of clarity and consensus regarding the goal of socletal racial integration:

If the integration ideology can be compared to a religion, school desegregation is the twentieth century equivalent of the Christian crusades. Issues that were once clear are now hopelessly confused. (Bell 1980: vili)

Apart from the goal of equal educational opportunity, school integration policies lack consensus and clarity. This ambiguity has resulted in a wide variety of school integration plans and policies at the local level. Consequently, the relationship between school integration and societal integration, e.g., student attitudes toward residential racial integration, needs to be studied on a case by case basis in the context of local district policy. School desegregation plans vary in many respects, e.g., racial composition of schools, voluntary versus mandatory school assignment, curriculum content, and racial composition of Instructional staff (Johnson 1976). Perhaps the most distinguishing characteristic of any school integration plan is its voluntary/mandatory nature. This aspect of school integration can be measured in two ways. First, whether or not a school district is under court order to desegregate is a nominal measure of voluntary versus mandatory integration. Second, the extent to which a school integration plan requires students to attend racially mixed schools constitutes another measure of the 
voluntary/mandatory nature of a given school integration plan.

In the case of Portland, oregon, the site for this study, the Portland Public school District has a school integration plan which is, and has been, viewed as voluntary (U.S. Commission on Civil Rights, 1977). Portland has never been under court order to desegregate its schools. The Portland Public school District has refrained from the mandatory assignment of white students to racially mixed schools for the purpose of school integration. However, as described later in this chapter, non-white students have, on occasion, been mandatorily bused to schools outside their neighborhood area.

The goal of societal racial integration, i.e. housing integration, has been historically linked to the voluntary nature of Portland's school integration plans and policies. The call for school desegregation in Portland began in the early 1968s. During that time the National Association for the Advancement of Colored People (NAACP) was active in calling for Portland to integrate its public schools. NAACP efforts were reported in the oregonian, october 22, 1962:

Earlier this year, two highly placed NAACP officials came from national headquarters to brief the local NAACP chapter on the drive for school integration in the northern states. Robert Carter, general counsel for The NAACR and Miss June shagaloff, NAACP staff aide who works full time in northern school integration, suggested the following measures to obtain through school authorities a more even distribution of Negro children throughout the school system: 
Where two adjacent school areas serve a Negro neighborhood and a white neighborhood, the two might be combined, with one building serving primary grades, the other the remainder of the elementary grades. Negro children might be transported by bus to schools with substantial white enrollment. New schools might be built on borders between Negro and white neighborhoods. (Oregontan 1962: 20)

In short, the NAACP was calling for the mandatory assignment of students to racially mixed schools and was thus advocating a mandatory school integration policy. In response to this proposal, the editorial board of the Qregonian urged caution. The newspaper expressed opposition to implementing the NAACP's school integration plan. In doing so the eregonian emphasized that school integration should facilitate rather than "obstruct" housing integration:

The NAACP program may very well be just the thing for those northern cities in which school district policies discriminate against Negro children; but this is Just not the case in Portland....

The real danger, as we see it, is that if the NAACP persists in the assault it has launched on the school board, it will raise animosities that will obstruct progress in the solution of the basic issue of housing segregation. (Emphasis added) (Oregonian 1962: 20)

Thus, during the early stages of school integration policy evolution in Portland, there was a clear linkage to societal integration. The editorlal board of the oregonian felt that school desegregation should be carried out in a 
manner that would foster rather than inhibit residential racial integration. The editorial board also felt that a mandatory policy would "raise animosities" between whites and non-Whites.

In response to the call for school desegregation, the Portland School Board appointed a "Committee on Race and Education." This committee concluded that it was the job of the public schools to bring about an integrated society by "preparing all students for life in an integrated society". (Committee on Race and Education 1964: 194) The committee also specified that to accomplish this goal the "school system should create contacts among children of all races sufficient to accustom them one to another." However, the committee stopped short of recommending mandatory student school assignments to bring about this interracial contact:

In general the concept of the neighborhood school is sound and preferable to any other system whlch has been suggested for the organization of school student populations. Experience elsewhere has demonstrated that indiscriminate dispersal of children on a quota basis is questionable education policy as well as disruptive of school organization. However, opportunity for both Negro and wite parents to transfer their children voluntarily from their neighborhood school to flll existing vacancies in other schools should produce favorable contact between chlldren of different races or different backgrounds on an individual and personal basis. (Race and Equal Educational Opportunity in Portland's Publle Schools 1964: 195-196)

From Its inception, Portland's school integration policy has been voluntary. Based on the above 
recommendations, Portland Public school District began a voluntary transfer program in 1964. Black families who wished to have their children bused to predominantly white schools outside their neighborhoods could do so provided there was space available at the recelving school. It was believed that this policy would "produce favorable contacts between children of different races." These favorable contacts would predispose students to live in an "integrated soclety."

In lts early years, Portland's voluntary school integration policy was not widely publicized nor pursued. By 1968, only 600 students (less than 1 percent of the District's enrollment) were attending schools outside the students' immediate nelghborhoods as a result of the school district's integration policy (Community coalition for School Integration 1978: 43). While some schools in the Black community had become slightly less segregated, others had become noticeably more segregated (see Table I). As a result the relationship between this type of school desegregation approach and meaningful racial integration began to be questioned. The lack of clear progress toward school integration resulted in a public outcry for the school district to take stronger measures:

The citizens' Committee for Better schools belleves that the time has come to embark on a vigorous public education program to acguaint the citizens of Portland with the existence of a large concentration of minority groups, particulariy Negroes (sic), and a continuing trend toward 
greater concentration. It is time Portland stated specific objectives for reducing racial Imbalance and design program steps to accelerate movement toward desegregation. (The citizens' Committee For Better Schools 1969: 1)

TABLE I

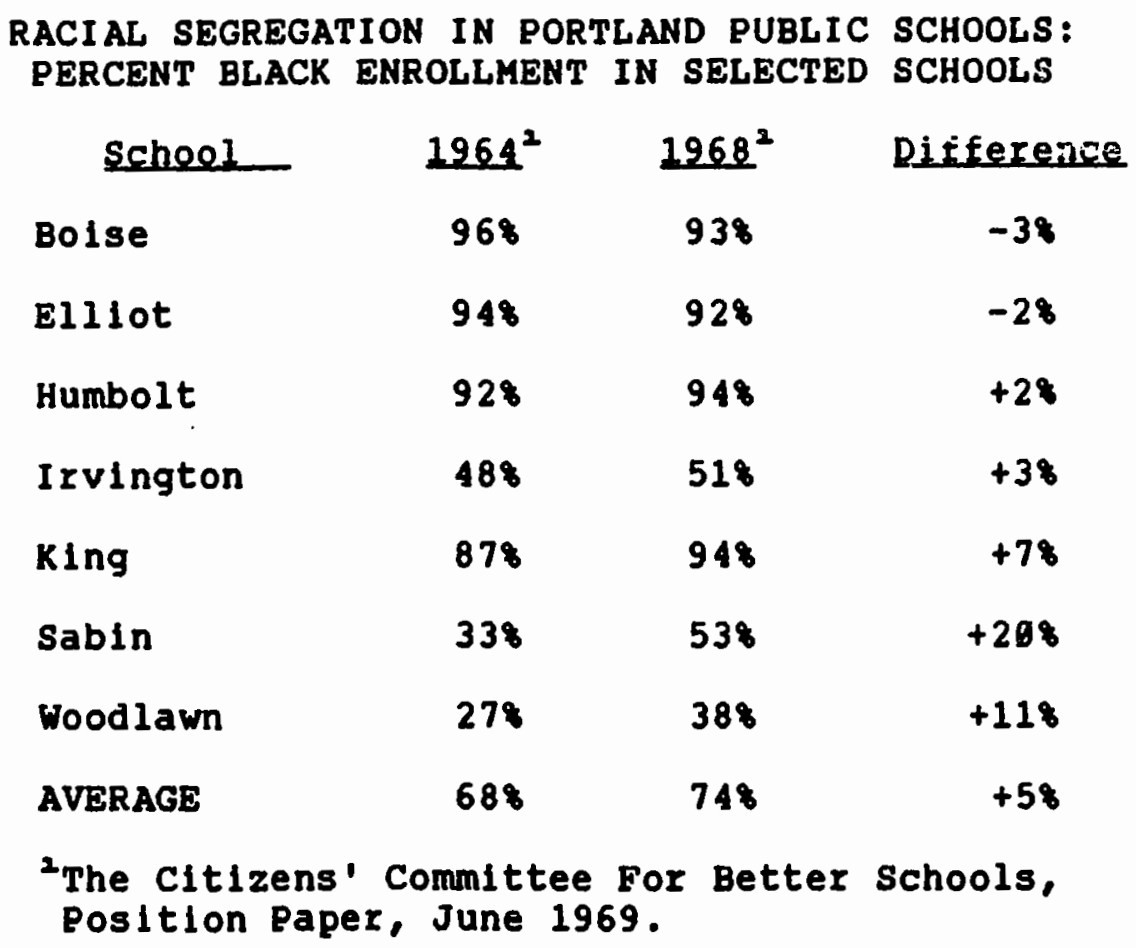

In response to public concern over the future of the Portland Public school system, including the persistence of racial segregation, the Portland School Board adopted a "Schools for the seventies" plan in 1970. This plan supported the continuation of the voluntary school integration policy. However, two aspects of the new plan represented a significant change in the Portland Public School District's school integration approach. These aspects were the proposed creation of Early Childhood 
Education Centers in the Black community and a concerted effort to increase the number of Black students involved in the voluntary student transfer program.

The "Schools for the Seventies Plan" stipulated that all elementary schools in the Black community were to be converted to Early Childhood Education centers (Portland Public schools, 1970). These centers were to consist of pre-school to fourth grades. The schools were to have "exemplary" pre-school programs that would attract the attendance of children outside the Black community. Transportation would be provided to children residing outside the Black community.

The creation of Early Childhood Education Centers in the Black community resulted in the mandatory assignment of Black students in gzades five to elght to schools outside the students' nelghborhood. This constituted a shift in school integration policy from totally voluntary to partiaily mandatory. For the first time student school assignment would be restricted as part of an overall effort to bring about racial integration.

The "Schools for the seventies Plan" also re-emphasized the District's existing voluntary desegregation policy. Part of this renewed emphasis involved putting pressure on Black families to assign their children to predominantly White schools outside the Black families' nelghborhoods. Rist (1978) has documented that in the early 1970s, the 
Portland Public school District hired a number of persons to go into the Black community and recruit Black children to be bused outside their neighborhood. Some of the "recruiters" reportedly told Black parents there was no longer room in neighborhood schools for their children. These recruiters generally extolled the benefits of attending schools outside the Black community.

In spite of these two policy changes, the portland Public School Distrlct still maintained it had a "voluntary" school integration plan. Moreover, the district was viewed by the federal government as having a "voluntary" school integration policy: "The desegregation process in Portland, oregon, is and has been voluntary" (U.S. Commission on Civil Rights, 1977). Portland continued its policy of avoiding the mandatory participation of whites. This conformed to its policy of bringing about racial integration without "disrupting" (White) neighborhood schools and in a manner that would create "favorable contact" between races.

By 1980 the policy changes described above had achieved significant results. Racial segregation in predominantly Black schools had been reduced an average of 24 percent (see Table II). In one school the Black enrollment had gone from 92 percent in 1968 to 39 percent in 1980 , a 53 percent decline! 
TABLE II

RACIAL SEGREGATION IN PORTLAND PUBLIC SCHOOLS: PERCENT BLACK ENROLLMENT IN SELECTED SCHOOLS

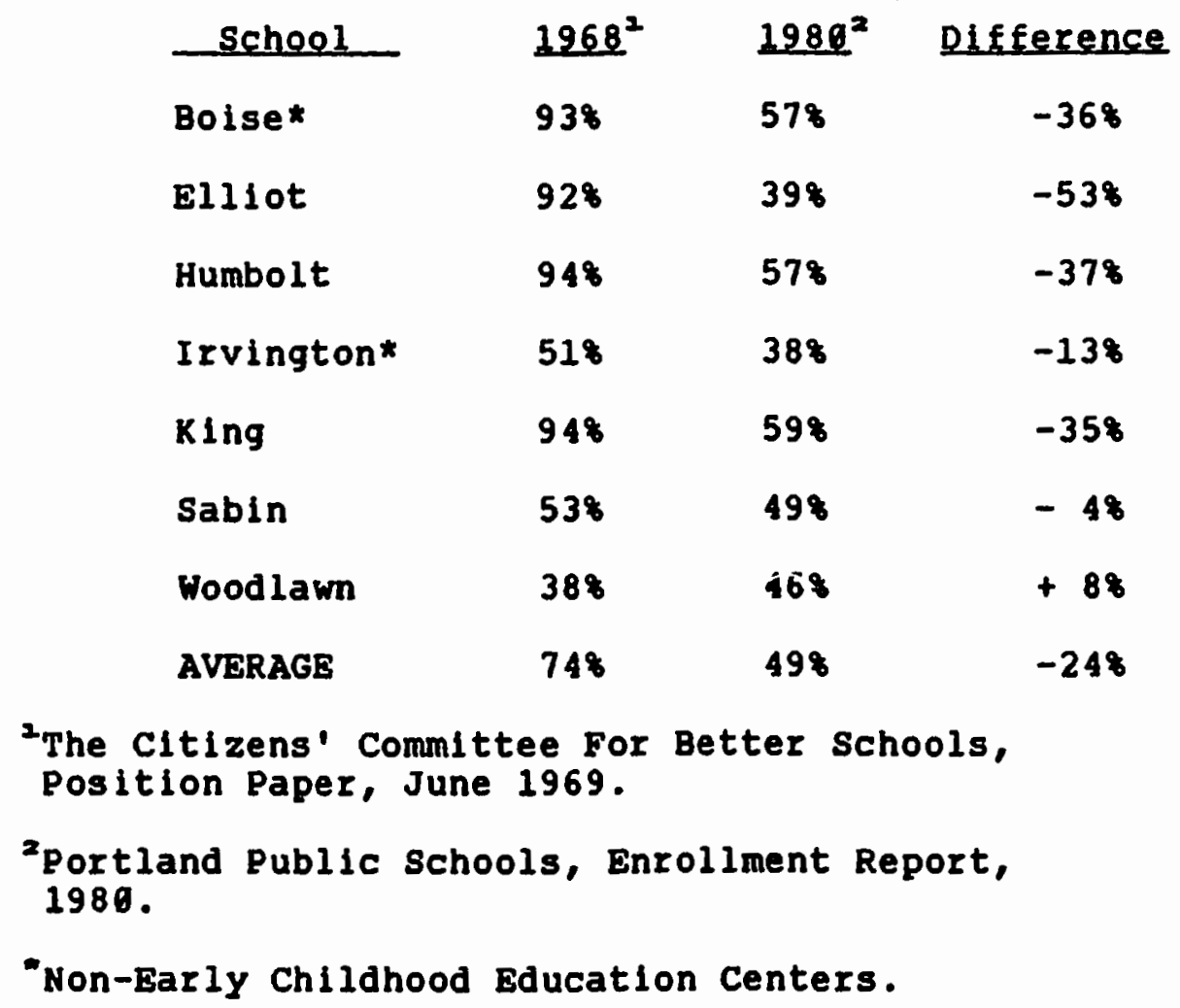

Progress toward racial desegregation, however, had "disrupted" neighborhoods in the Black community. The loss of fifth through elghth grade elementary school options and the heavy recruitment of Black students to attend schools outside the Black community resulted in the scattering of Black students throughout the school district. For example, Black students in the King school neighborhood were bused to 39 different schools within the Portland school District (Community Coalition For school Integration 1978). In some cases, these students were bused over 20 miles a day (see Table III). 
TABLE III

ASSIGNMENT OF BLACK SIUDENTS TO SCHOOLS OUTSIDE BLACK NEIGHBORHOODS BY SCHOOL NEIGHBORHOOD AREA ${ }^{2}$

\begin{tabular}{|c|c|c|c|}
\hline Neighborhood & $\frac{\text { No. of students }}{\frac{\text { Ass laned to }}{\text { Other schools }}}$ & $\frac{\text { No. of }}{\text { other }}$ & $\begin{array}{l}\text { Distance } \\
\text { Traveled } \\
\text { (Reund- } \\
\text { Trio) }\end{array}$ \\
\hline KIng & 451 & 39 & $\begin{array}{r}4.2-21.4 \\
\text { miles }\end{array}$ \\
\hline Sabln & 179 & 16 & $\begin{array}{c}2.6-22 \\
\text { miles }\end{array}$ \\
\hline Boise & 154 & 22 & $\begin{array}{r}4.8-18.2 \\
\text { miles }\end{array}$ \\
\hline E111ot & 44 & 28 & $\begin{array}{r}4.2-19.4 \\
\text { miles }\end{array}$ \\
\hline Woodlawn & 238 & 21 & $\begin{array}{r}4.6-23.1 \\
\text { miles }\end{array}$ \\
\hline Humbolt & 276 & 25 & $\begin{array}{r}7.2-21.6 \\
\text { miles }\end{array}$ \\
\hline
\end{tabular}

${ }^{2}$ Community Coalition for school Integration, 1978.

The experience at the end of the bus ride for Black students transported out of their neighborhoods was often negative. The students and staff at the predominantly white schools to which the Black students were bused were insensitive to their unique cultural backgrounds. In short, their presence was largely ignored. Iittle or no effort was made to change instruction or curriculum to accommodate them. Furthermore, no effort was made to counteract the negative effects of being removed from one's neighborhood environment and, therefore, being subject to isolation both 
at home and at the receiving school (Johnson, 1976; Rist, $1978)$.

Concern over the mandatory busing of Black students outside their neighborhood and community resulted in the formation of a Community Coalition For school Integration in the fall of 1977. This Coalition was a broad-based group consisting of representatives from 38 civic groups, e.g. NAACP, Portland Chamber of Commerce, and the National Conference of Christians and Jews. After a year of study the coalition found the Portland Public school District's implementation of its school integration policy discriminatory:

The mandatory elimination of grade levels in all of the elementary schools (in the Black Community), except Boise, has not been carried out in any other community in the District. students leaving the Black Community for the purpose of school desegregation have been scattered and isolated throughout the whole school oistrict. For example, the 44 students having to leave the Elilot neighborhood in 1977 were bused to 20 different schools throughout the District. (Community Coalition For School Integration 1978: 61)

This finding, among others, lead the community Coalition to recommend a "school palring plan" as a better, more equitable way of implementing the District's school integration policy:

The school District should use school pairing as the major means to accomplish desegregation/integration. The District should pair each of the seven predominantly Minority schools in the District with one or two predominantly White schools in a manner that will 
comply with state guidelines on racial balance. (Community Coalition For school Integration 1978: 87)

In essence, the Coalition was recommending that the Portland Public school District adopt a "mandatory" school integration policy. School pairing constitutes mandatory school Integration in that both White and non-White students are mandated to attend assigned schools for desegregation purposes. Such a shift in policy met strong resistance from the superintendent and the school Board.

In response to the Community Coalition's recommendations, the District superintendent claimed that the Portland Rublic School District's voluntary school integration policy had "helped stabilize neighborhoods" and avolded "middle class flight from the city" (Portland Public schools, 1978: 3). The District superintendent also stated that "housing, not education, is the ultimate key to the racial integration of urban society" and that the "compulsory two-way transportation" recommendation of the Coalition would "accelerate" middle-class flight from the city (Portland Public schools 1978: 20, 31).

The Portland school Board went on to reject the Community Coalition's school pairing plan, i.e., mandatory integration policy. In so doing, it reaffirmed its longstanding position of pursuing a "voluntary" school integration policy that would continue to "stabilize neighborhoods" and contribute to the ultimate solution or 
"key" of housing integration.

In the aftermath of the school Board's rejection of the Coalition's mandatory, two-way, student assignment recommendation, a Black United Front Organlzation emerged. The Black United Front consisted mainly of organizations and nelghborhood groups in the Black Communlty, many of whom had been members of the community coalition For school Integration. The Black United Front became primarily concerned with restoring elementary and middle school (grades four through eight) options within the Black community:

After fifteen years of transferring Black
children to schools outside of their neighborhood,
we find no academic or psychological reason for
continuing this process. (Black United Front 1989)

The Black United Front was successful in getting the Portland School Board to establish a middle school (grades six through eight) in the Black community and to discontinue Its practice of recruiting Black children for transfer to predominantly white schools outside the Black community. These changes were incorporated in a new portland Public School District school integration plan adopted in 1980. This new plan underscored the voluntary nature of Portland's school integration policy:

The Desegregation Plan seeks to achleve its goals by encouraging portland families to voluntarily choose integrated schools, either through their cholces of residential neighborhoods 
or through attendance at schools in other
nelghborhoods. Its twin features are (1)
availability of quality education in an assigned
school for all chlldren; (2) well developed,
attractive special programs in some schools.
(Portland public schools 1980: 8)

In summary, from its beginning school integration policy in Portland has, with the exception of the mandatory busing of Black students, been voluntary in nature. In accordance with the tradition of using public schooling as a means of soclal change, Portland's school integration policy has also been viewed as having to contribute to the ultimate goal of socletal integration, l.e., housing or residential integration. This was to be accomplished by bringing about "favorable contact" between races. It was felt that a school integration policy that was voluntary, at least for White students, would foster positive interracial contact in schools and create positive attitudes that would function as a precursor to residential racial integration.

This dissertation will examine the extent to which school integration experience is positively related to student attitudes toward residential racial integration. 


\section{REVIEW OF THE LITERATURE ON THE RELATIONSHIP BETWEEN SCHOOL INTEGRATION AND RESIDENTIAL RACIAL INTEGRATION}

As explained in the first chapter, it has been thought that raclal integration in the public schools would lead to a greater level of societal integration. This was to occur as the result of students acquiring positive interracial attitudes through their school integration experiences. In the case of Portland, oregon residential racial integration was cited as a long-term objective of interracial contact in the schools. School integration policy and plans have now been in effect long enough to permit an examination of their relation to residential raclal integration attitudes.

\section{RESIDENTIAL INTEGRATION TRENDS}

An examination of census data on racial composition of residential areas in the United states show that there has been little or no movement toward increased residentlal racial integration in recent years. Using an index of dissimilarity, l.e. the percentage of Blacks or whites that would have to move in order for each census tract to have the same racial composition as the entire SMSA, Van Valey (1977) found that, for the 144 U.S. SMSAs for which 
comparable data were available in both the 1960 and the 1970 census, there was no significant change in residential racial integration. Van valey's results were supported by Schnare's (1980) analysis of the same data. Using the proportion of Whites present in the average Black's census tract, schnare concluded that the average Black experlenced an Increase in segregation, 1.e., 30 percent white census track composition versus 33 percent composition, between 1960 and 1970.

Analysis of 1980 census data indicate that residential racial segregation patterns persist. Using the index of dissimilarity, Farley (1983) found that residential racial segregation slightly increased in St. Louls between 1970 and 1980. Winsberg (1983) examined racial residential trends in Florida's ten SMSAs between 1970 and 1980 and concluded that only slightly fewer Blacks were living in census tracks with 88 percent Black composition in 1980 than in 1970.

An examination of census data for the city of Portland, Oregon, indicates a slight decrease in the level of residential segregation between 1970 and 1980 . Selected census tracks with high Black composition show an average decline of three percent in Black population between 1970 and 1980 (see Table IV). 
TABLB IV

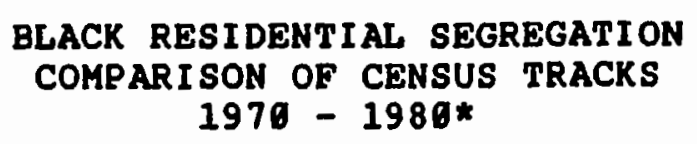

\begin{tabular}{|c|c|c|c|}
\hline & 1970 & 1980 & Loss/ \\
\hline Census Track & Rercent Black & Percent Black & Gain \\
\hline 0622.01 & 508 & $35 t$ & -158 \\
\hline 0022.02 & 548 & 438 & -118 \\
\hline 0023.61 & 778 & 628 & $-15 \%$ \\
\hline 0023.62 & 458 & 288 & -178 \\
\hline 6624.01 & 138 & 388 & -58 \\
\hline 6032 & 228 & 378 & +158 \\
\hline 0033.01 & 618 & 638 & +28 \\
\hline 0033.02 & 628 & 648 & +28 \\
\hline 0034.81 & 658 & 698 & +48 \\
\hline 0634.62 & 848 & 738 & -118 \\
\hline 0036.01 & 362 & 492 & \pm 138 \\
\hline & MEAN $=548$ & MEAN $=518$ & $1=-38$ \\
\hline
\end{tabular}

*Source: 1978 and 1980 U.S. Census

The finding that residential racial segregation has continued during the initial fifteen years of school Integration is not inconsistent with the public schooling as social change perspective. In order to impact residential segregation, school integration would first have to change the Interracial attitudes of students. These students would then have to actualize these positive interracial attitudes 
in their residential choice behavior. Such an impact would evidence itself in the long-term, 1.e. after students leave public schools and are in a position to exhibit residential choice behavior.

SCHOOL INTEGRATION AND RESIDENTIAL INTEGRATION

Although there is some evidence of slight reductions in residential racial segregation, the dominant pattern of residential racial segregation has persisted during the initial period of school integration policy, 1.e., 1960 to 1980. Where slight reductions in residential segregation have occurred, school integration has been cited as a contributing factor:

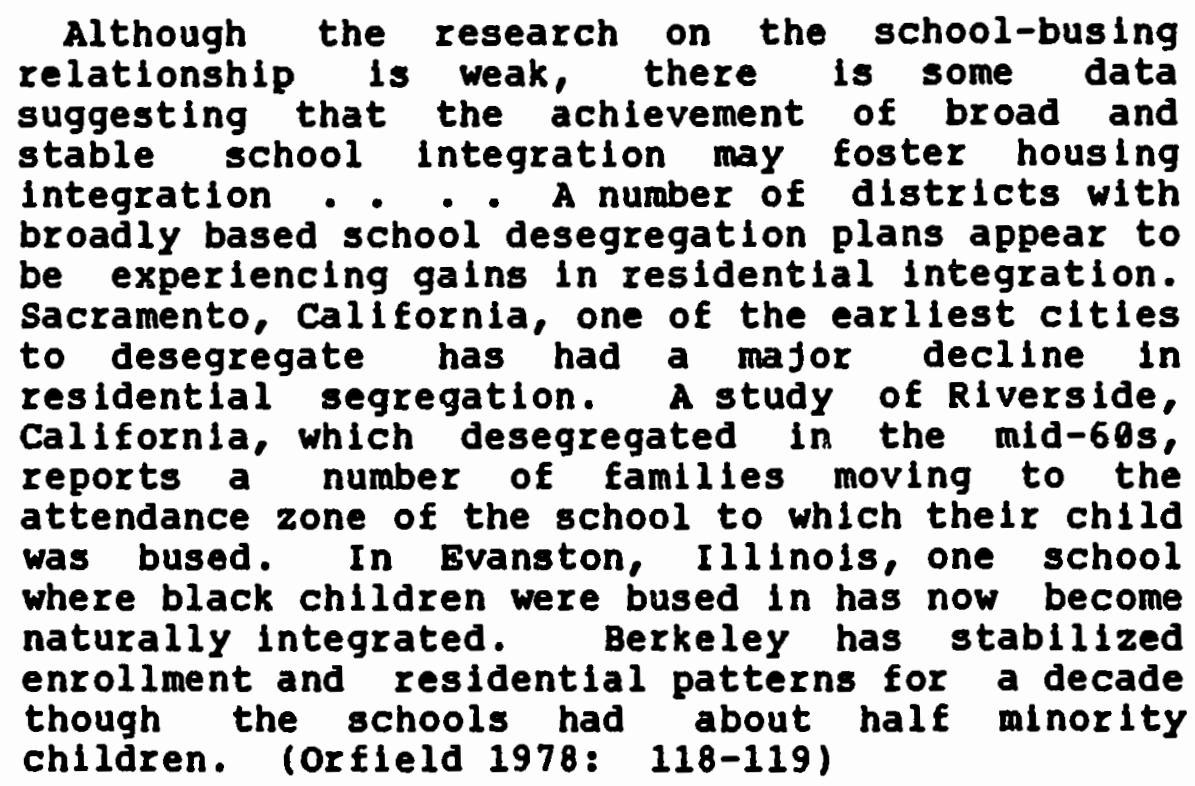

orfleld (1978) falls to develop more than a circumstantial relationship between residential racial integration 
and school desegregation. The examples of increased residential integration cited could be attributed to other factors besides school integration, e.g, re-gentrification. In a survey of persons residing in integrated neighborhoods, Bradburn, Sudman, and Gockel (1978) found that other factors such as convenience of work, features of the dwelling, and financial consideration were more important than schools in determining residential choice.

In an attempt to develop a direct relationship between school Integration and residential integration, Pearce (1981) examined the behavior of real estate agents in school districts engaged in school integration. Seven pairs of school districts were matched in terms of size, region of the country, and minority racial composition. Pearce found that schools were mentioned as an important location factor more often by real estate agents in school districts not involved in desegrigation. On the basis of this finding, Pearce concluded that school integration is positively related to residential integration in that real estate agents are less likely to steer customers to raclally segregated neighborhoods in desegregated school districts. In support of Pearce's conclusion, Hawley (1983) maintains that school integration makes it impossible for White families to choose to live in nelghborhoods with segregated schools; therefore, it reduces their propensity to reside in raclally segregated nelghborhoods. 
The research cited above falls to confirm adequately a direct relationship between school integration and residential integration. Rather, the evidence presented merely suggests a relationship may exist. Furthermore, these findings fall to establish a relationship between the school integration experience and residential choice behavior. The first step in establishing such a relationship is to ascertain whether there is a relationship between school integration experience and attitudes toward living in an integrated neighborhood. subsequently, an analysis could be made to determine the relative importance of these attitudes in residential cholce behavior. This dissertation will focus on the first step. Ultimately, a relationship between school integration and residential integration will be substantiated or negated by the residential choice attitudes of students who have experlenced school integration.

There is little research on the relationship between school integration and student attitudes toward residential choice. The most often cited study in this area was conducted by the National Opinion Research Center (NORC) in the $1960 \mathrm{~s}$ (U.S. Commission on Civil Rights 1967). The source of data for this study was interviews with 1,624 Black adults from the metropolitan North and a national sample of 979 White adults. The results of the NORC study Indicated that Blacks who attended integrated schools in the 
North were more wiling to move into predominantly White neighborhoods and Whites who attended integrated schools were more accepting of Blacks living in their neighborhood blocks (U.S. Commission on Civil Rights, 1967).

The NORC study falled in two ways to establish a clear relationship between school integration and attitudes toward residential integration. First, the school integration experience was not adequately measured. Nominal data on whether or not someone reports attending an integrated school lacks sufficient precision to substantiate a relationship. The NORC study falled to measure the amount or extent of interracial contact. Consequently, it is impossible to conclude that interracial contact in a school integration setting is directly related to the greater propensity toward residential racial integration among Blacks and Whites.

second, the question on residential integration for Whites focused upon whether or not it would make any difference if a Black moved into their neighborhood, l.e., "If a Negro moved into your block, would it make any difference to you?" Responses to this question did not indicate the extent to which whites were willing to locate In an integrated neighborhood. Rather, these responses ylelded only nominal data on white tolerance for an in-migration of one Black into their neighborhood. As such, the NORC study falled to measure behavioral attitude toward 
racial residentlal integration on the part of whites.

MEASURING THE SCHOOL INTEGRATION EXPERIENCE

School integration is a complex phenomenon that can be measured in many ways (Johnson 1976; Hawley, Russe11, and Crain 1983). For example, the amount of interracial contact, grade level at which the school integration begins, and extent of participation in racially integrated extracurricular activities constitute different measures of the school integration experience. Moreover, these varlous aspects of school integration experience lend themselves to ordinal or interval measurement. such measurement should provide better data on the relationship between school Integration and student attitudes toward residential racial integration.

The literature suggests that certain aspects of school integration are salient in terms of its relationship to student attitudes toward housing integration. These factors are described below along with their hypothesized relationship to racial residential integration attitudes. Amount of Interracial contact and Attitudes Toward Residential Integration

It has long been held that interracial or majorityminority group contact is a necessary prerequisite to improved relations between races (Myrdal 1944; Allport 1954). It has also been held that the nature of contact is 
important. Interracial contact under some circumstances, e.g., unequal status contact where the Black person is in an Inferlor role such as maid or laborer and the white person is in a superior role such as banker or lawyer, can reinforce racial stereotypes and thereby not improve interracial understanding or acceptance. Interracial contact of a positive nature, e.g. working on a team, may lessen racial stereotypes and consequently improve interraclal understanding and acceptance.

Allport (1954) listed three conditions under which interracial contact would lessen stereotypes and improve race relations. The first is that the contact should occur in a setting in which the mafority and minority groups have equal status. The second is that the contact should occur in an ordinary, purposeful pursuit. The third condition is that the interracial contact have institution and community sanction.

All three of Allport's conditions for positive interracial contact are potentially present in the school integration experience. Whites and Non-Whites are equal in their status as students; public school is an ordinary, purposeful pursuit; school integration has institutional (school district) and community (lawful) sanction. Consequently, based on Allport's theory, interracial contact occurring in an integrated school should reduce racial prejudice and improve race relations. Moreover, the amount 
of interracial contact in a school integration setting should be positively related to attitudes toward residential racial integration.

The onset of the school Integration Experience and At 1tudes Toward Residential Integration.

Allport (1954) also found that the age at which a person is exposed to racial integration was important in determining whether or not an individual would have a positive attitude toward racial integration:

These findings clearly support the American studies we have reported, and make us feel doubly sure that early training is an important agent in slanting a chlid toward tolerance toward other groups. (Allport 1954: 128)

Allport's contention about the importance of early age exposure to racial integration in determining one's racial attitudes has been substantiated by a number of studies (st. John 1975; Goldstein et al. 1979; Hawley et al. 1983). The research of Allport and others leads to the hypothesis that early-age school integration experlence, 1.e. onset of contact, should be positively related to attitudes toward residential racial integration.

Rarticipation in Integrated Extracure lcular Activities and At itudes Toward Residential Integration.

In his seminal work on the economic and social position of Blacks in American society, Gunner Myrdal

theorlzed that cooperation and fellowship between Blacks and Whites would foster mutual acceptance and attraction:

Our general hypothesis is that everything which brings Negro and white workers to experience 
intimate cooperation and fellowship will on the balance, breakdown race prejudice somewhat and raise Negro status. (Myrdal 1944: 654)

One measure of cooperation and fellowship in the public school system is involvement in extracurricular activities, e.g., athletic teams and school clubs. In a study of 200 racially integrated Southern high schools, Crain (1981) found a relationship between involvement in racially integrated extracurricular activities and positive interracial relations. Black and white students from "high (extracuricular) participation schools," 1.e., schools in which four-fifths of the student body said they participated In extracurricular activities, more frequently had opposite race frlends than students from "low (extracurricular) participation schools."

The above research suggests that participation in racially integrated extracurricular activities should be positively related to attitudes toward residential racial integration.

The Relationshio Between school Integration and Attitudes Toward Residential Racial Integration: consideration of Antecedent Variables.

In examining the relationship between school integration and student attitudes toward residential integration, it is important to take into account other influential factors independent of the school integration experience. This has been referred to as the process of "elaboration" by Rosenberg (1968). 
There are a number of factors that are antecedent to the school integration experlence which may influence the relationship between school integration and student attitudes toward residential integration. Race, famlly educational background, and nelghborhood background are all characteristics the student brings to the school experience. These variables have been identified as having the potential to influence interracial attitudes significantly.

After reviewing 41 studies on the effects of school-age interraclal contact on racial prejudice, st. John (1975) concluded that the results were inconsistent and in some cases differential for Blacks and whites. "Sometimes desegregation is reported to have ameliorated the prefudice of whites but intensified that of blacks, sometimes the reverse" (st. John 1975: 67-68). Furthermore, st. John was unable to account for the differential results she found. Her general finding, however, suggests that school integration may have different outcomes depending on one's race. Consequently, race needs to be treated as a potentially significant antecedent varlable when considering the relationship between school integration experience and student attitudes toward residential integration.

Another important factor which has long been considered Important in determining one's attitude toward other races is educational background (Allport 1951). The more educated one 1s, the more accepting and less prejudiced one should be 
toward other racial groups. This lends to the conjecture that students from families in which the parents are more highly educated may be predisposed to positive attitudes toward residential integration, irrespective of the students' school integration experlence. The reverse may apply for students who have parents with poor educational background. Therefore, family educational background should be recognized as a potentially significant antecedent varlable influencing the relationship between school Integration experience and student attitudes toward residential integration.

A student's nelghborhood environment may also influence or shape his/her racial attitudes prlor to and Independent of school experience. In a review of the literature on racial attitudes among Blacks and whites, Darden and Parsen (1981) conclude that in order to understand interracial attitudes, one must take into account neighborhood racial composition. Consequently, neighborhood racial composition may have a significant impact on the relationship between school integration experience and student attitudes toward residential integration.

Ability grouping or educational tracking, one of the most common educational practices in American public schools (National Education Association 1968; Esposito 1973), may also influence the school integration experience. Ability grouping is the differentiation and instructional group 
assignment of students based on their percelved aptitudes and potential. Ability grouping begins as early as the first grade with assignment to a particular reading group level and continues on through high school with placement of students into college and non-college curriculum tracks.

The prevalence of educational tracking has been cited as a significant factor in understanding the relationship between school integration and student racial attitudes (simmons and Brady 1981). If, on the average, fewer minority students are assigned to the college track group in a particular high school, interracial contact for college track students would be minimized. on the other hand, interracial contact among non-college track students would be maximized.

Educational tracking, however, is important only to the extent that interracial contact is important. Consequently, it must first be established that the "amount" of Interracial contact is significantly related to student attitudes toward residential integration. If this is the case, only then does educational tracking take on any significance as an intervening variable in the relationship between school integration and student attitudes toward housing integration.

In summary, there appears to have been little or no reduction in residential racial segregation during the Initial period of school integration pollcy, 1.e. 1965-1980. 
This would be expected given the focus of social change, students. Students affected by school integration experiences would, for the most part, not have entered the housing market prior to 1980 . In order to determine the impact of school integration on residential integration in the long-run, the relationship between school integration experiences and attitudes toward residential integration must first be explored.

In order to examine the relationship between school integration and student attitudes toward residential integration, school integration must be measured in a manner consistent with its complex nature. Three important ways In which school integration plans vary are the amount of Interracial contact, the onset of interracial contact, and participation in integrated extracurricular activities. The relationship between school integration and attitudes toward residential integration must also be considered in the context of characteristics which the student brings to the integration experience. These characteristics include race, parents' educational background, and neighborhood racial composition. Finally, to the extent that the amount of interracial contact is important, educational tracking may be an important intervening variable influencing the relationship between school integration and student attitudes toward residential racial integration. 
CHAPTER II I

RESEARCH SETTING AND METHODOLOGY

Given the focus of this study, student attitudes toward residential racial integration, survey research was employed. Survey research allows the collection of information from many students in a manner that is feasible and acceptable within the contines ot the public education system. It aiso provides a vehicle for gathering information on student integration experiences.

survey research also lends itselt to statistical analyses appropriate to the question at hand. students' attitudes and experiences can be recorded in a manner that translates into interval measurement. Interval measures can, in turn, be used to determine the relationship between school integration and student attitudes toward residential integration. Such data can be analyzed by using various correlation and regression techniques.

\section{RESEARCH SETTING}

Portland, Oregon, was selected as the site tor this study because its urban school district exhibits a large variation of school integration experiences. Non-White enrollment ranges from two percent to 90 percent among the 
district's schools (Portland Public schools, 1986). This led to an expectation that student experience would vary widely with regard to the amount of interracial contact and participation in integrated extracurricular activities.

As mentioned in Chapter one, a major feature of the Portland ?ublic school vistrict's integration policy has been the creation of Early childhood Education centers in the Black community. Students attending these centers experience school integration as early as the prekindergarten level. Given the large variations in non-white enrollment, students not attending Early Childhood Education Centers might not experience integration until much later in their public school careers. Thus, it was anticipated that students attending the fortland public schools would vary considerably in the onset of their school integration experience.

The racial composition of the Portland Public schools is most comparable to moderate sized mid-western urban areas such as Omaha and Minneapolis. In general, the Portland Rublic Schools contain fewer non-White and Blacks than other U.S. cities (see Table V). 
TABLE V

RACIAL COMPOSITION OF
PORTLAND PUBLIC SCHOOLS
$\begin{array}{cc}\text { Portland } & \text { National SMSA } \\ \text { Public } & \text { Central } \\ \text { Schools } & \text { Cities } \\ 738 & 658 \\ 278 & 358\end{array}$

$\begin{array}{lcc}\text { Black } & 158 & 268 \\ \text { Indian } & 28 & 18 \\ \text { Asian } & 88 & 38 \\ \text { Spanish } & 28 & 128 \\ \text { Origin* } & \\ \text { 2Enroliment Report, Management Information Services, } \\ \text { Portland Public Schools, 1986. }\end{array}$

zU.S. Department of Commerce. 1980 Census of population, Vol. 2. Subject Reports:Poverty Areas in Large cities. U.S. Department of Commerce, Washington, DC.

* Persons of Spanish origin may also be counted as a member of any other race.

The difference in minority composition, however, is not extreme ( 27 percent non-white versus 35 percent non-white), and Blacks are the largest non-white population group for Portland Public Schools as well as U.S. SMSA Central Cities, comprising 15 percent and 26 percent of the total population respectively. The Portland Public school Districts differs from that of other sMsa Central citles in that Asians, not 
Hispanics, are the second largest Non-White group.

The mafor theoretical models of mafority/minority race relations are not specific to race (Allport, 1954). Consequently, differences in racial composition between the Portland Public schools and other U.S. urban areas are not relevant to the theoretical hypotheses under consideration. That is to say, the amount, onset, and nature of majority/ minority contact are thought to affect mafority/minority race relations regardless of which race(s) constitute the minority or majority groups.

SURVEY INSTRUMENT: VARIABLES AND MEASURES

A survey instrument was constructed to measure school integration experiences, attitude toward residential raclal integration, and the potentially influential antecedent variables identified in Chapter Two (see complete survey instrument in Appendis A). The survey instrument was constructed to include the following measurement scalas. Classroom Racial composition scale (CRC):

White student Response

1068 White

908 White

898 White

708 White

608 white score

1

2

3

4

5
Non-White student Response

score

1008 Non-White 1

90\% Non-White 2

808 Non-White 3

78\% Non-White 4

608 Non-White 5 


$\begin{array}{lccr}508 \text { White } & 6 & 588 \text { Non-White } & 6 \\ 408 \text { White } & 7 & 408 \text { Non-White } & 7 \\ 308 \text { White } & 8 & 308 \text { Non-White } \\ 208 \text { White } & 9 & 208 \text { Non-White } & 8 \\ 108 \text { White } & 10 & 108 \text { Non-White }\end{array}$

This scale was designed to measure responses to the question, "On the average, the racial composition of the classrooms I attended was . . ." The scale assigns increasing values to the presence of the other group, 1.e., White or non-white members present in the classroom. The range of racial composition averages used in the survey was based on two considerations. The first consideration was that the actual racial composition in the Portland school District ranged from two percent non-white to 90 percent non-white enrollment. The second consideration was to provide enough possible response options (ten) for students to approximate their percelved experiences.

The rationale for this scale is based on probability of interracial contact. It is assumed that the greater the proportion of other groups (White or Non-white) present in the classroom, the more likely interracial contact will occur. As described in Chapter II, values obtained by this measurement should be positively related to attitudes toward residential racial integration. 
enset of School Integration Experience scale (OSI):

$\begin{array}{lccc}\text { Response } & \text { Score } & \text { Response } & \text { Score } \\ \text { Pre-kindergarten } & 14 & 6 \text { th grade } & 7 \\ \text { Kindergarten } & 13 & 7 \text { th grade } & 6 \\ \text { 1st grade } & 12 & 8 \text { th grade } & 5 \\ \text { 2nd grade } & 11 & 9 \text { th grade } & 4 \\ \text { 3rd grade } & 10 & 16 \text { th grade } & 3 \\ \text { 4th grade } & 9 & 11 \text { th grade } & 2 \\ 5 \text { th grade } & 8 & 12 \text { th grade } & 1\end{array}$

Responses to the question, "I attended classrooms with both non-white and white students in the following grades. - ." were converted into the above scale. Thls scale assigns decreasing values as the grade level of Initial interracial contact increases. The range of responses begins at the pre-kindergarten level because of the existence of Early Childhood Education centers in the Portland school District. These schools start at the prekIndergarten level. As explained in Chapter II, measures recorded by this scale should be positively related to student attitudes toward residentlal raclal integration.

Involvement In integrated sxtracurricular Activities scale (BA):

$\begin{array}{lc}\text { Response } & \text { score } \\ \text { One activity } & 1 \\ \text { Two activities } & 2 \\ \text { Three activities } & 3\end{array}$


Four activities 4

Five activities $\quad 5$

Etc.

This scale measures the extent of participation in integrated extracurricular activities as derived from responses to the question, "I participated in extracurricular school activities with both non-white and White students. If yes, list the extracurricular activities." This scale is based on the assumption that the more integrated extracurricular activities in which a student engages, the more likely he/she wlll have experienced positive interracial cooperation and teamwork. Thus, obtained values from this measurement should be positively related to attitudes toward residential racial integration.

\section{Behavioral Attitude scale (BA):}

As discussed in Chapter II, a direct link between school integration experience and attitude toward residential racial integration has yet to be established. Attitudes are generally thought to have three components: affective, cognitive, and behavioral (Secord and Backman, 1964). How a person "feels" about something is referred to as affective attitude. A person's "thoughts" and "beliefs" are called cognitive attitude. An Individual's predisposition to act is designated as $\mathrm{his} / \mathrm{her}$ behavioral attitude. Since the focus of this study is on a student's 
predisposition to reside in a racially integrated neighborhood, the latter attitudinal component was chosen for measurement.

The 1 iterature indicates that attitudes are related to behavior when they are measured in a manner that reveals a clear behavioral referent (Ajzen and Fishbein, 1977). Consequently, attitude toward racial residential integration needs to be measured in a manner that reflects a clear behavioral choice. For example, an individual may "feel" or "think" positively about residential racial integration but choose not to live in a racially integrated neighborhood. It is therefore important that a survey question regarding attitude toward residential racial integration have a behavioral context, e.g., "I would live in a racially integrated neighborhood block." In light of this reasoning, student attitude toward residential racial integration was measured by responses to the following question: "Assuming I could live anywhere I wanted to, I would live in a neighborhood block that is 1098 White to 100\% non-White." Responses were converted into the following scale.

White student Response

1068 White

908 White

80\% White

708 White score

1

2

3

4
Non-white student Response

Score

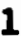
908 Non-white 2

708 Non-White

808 Non-white 3 4 


$\begin{array}{lrrr}608 \text { White } & 5 & 608 \text { Non-white } & 5 \\ 508 \text { white } & 6 & 508 \text { Non-White } & 6 \\ 408 \text { white } & 7 & 408 \text { Non-White } & 7 \\ 308 \text { white } & 8 & 308 \text { Non-White } & 8 \\ 208 \text { White } & 9 & 208 \text { Non-White } & 9 \\ 108 \text { white } & 10 & 108 \text { Non-White } & 10 \\ 1008 \text { Non-White } & 11 & 1008 \text { White } & 11\end{array}$

The above scale is based on assigning increasing values in relation to the increasing proportion of the other group present in the neighborhood-block choice. Thus, this scale measures the extent to which the respondent would lecate. In a neighborhood that has members of another race, $1 . e .^{-}$it measures behavioral attitude.

Antecedent Varlables: Race (RA), Parents' Educational Background (PBB), and Nelghborhood Raclal Compos ltion (NRC)

As mentioned in the previous chapter, the relationship between school integration and attitude toward residential integration needs to be examined in the context of potentially influential, antecedent variables. Such variables Include race, family educational background, and neighborhood racial composition.

The race varlable was measured by student responses to a question asking students if they were white or non-white. The white/non-White dichotomy was used to conform to the theoretical literature on majority/minority race relations (Allport, 1954). In this case "White" constitutes the 
majority race, and "Non-White" constitutes the minority races. As described earlier, Blacks comprise the largest proportion of the Portland Public school's nori-White population. The White/non-White classification was also used because Portland Public School research staff Indicated they recelved more rellable survey information when using this racial classification than when they attempted to have students list their unique racial background.

As described in the previous chapter, educational background has been found to be related to interracial attitudes (Allport 1954). Higher education is thought to lead to increased interracial tolerance and acceptance. Thus students from highly educated families may be predisposed to have a positive attitude toward residential integration of their school integration experience. Likewise, students from less educated families may be predisposed to have negative or neutral attitudes toward residential racial mixing. In order to account for this variable in the analysis, students were asked whether or not the1r parents or parent graduated from college. Those answering "yes" were classifled as having high educational background. Those answering "no" were deslgnated as having low educational background.

Next to school and family, children spend most of their time in their neighborhood environment. They also experience their nelghborhood before they experience school. 
As pointed out in the last chapter, neighborhood racial composition has been found to be related to interracial attltudes (Darden and Parsen, 1981). Interracial contact in the "equal status" context of one's neighborhood environment may foster positive interracial attitudes prior to and independent of school integration experience. Neighborhood racial composition was measured by the same scale used to measure classroom racial composition and behavioral attitude toward residential racial integration:

White student

Response

1008 White

90\% White

808 White

708 White

608 White

508 White

40\% White

30\% White

208 White

108 White score

1

2

3

4

5

6

7

8

9

10
Nen-white student. Response

100\% Non-White

968 Non-White

808 Non-White

768 Non-White

608 Non-White

508 Non-White

408 Non-white

308 Non-white

208 Non-White

108 Non-White
Score

1

2

3

4

5

6

7

8

9

10

As with previous scales, this one assigns increasing values commensurate with the increasing proportion of other racial group members present. With this information, the relationship between school integration and attitudes toward residential racial integration can be observed while 
controlling for the influence of neighborhood racial composition.

\section{DATA COLLECTION AND SAMPLE}

It took two years to obtain student attitudinal data for this study. The chronicle of gaining entrance into Portland Public schools to collect these data is elaborated in Appendix B. High school seniors in the graduating class of 1987 were the sample universe for this study. Seniors were chosen because they had experienced school integration the longest, and they were closer to having to make actual residential choices than were other students. A question on residential racial integration thus would be more meaningful to seniors than to their underclass counterparts.

Four high schools were included in the survey: Benson, Grant, Lincoln and Madison. As explained in Appendix B, these were the high schools where the principals allowed access. The District administration would not allow access in cases where the principal did not want $\mathrm{hls} / \mathrm{her}$ students surveyed. Although self-selected, these four high schools have a minority student composition similar to the district's total high school minority composition, 1.e. 288 vs. 27\%, respectively. The four high schools included in the sample also represent both the west and east areas of the Portland school District.

In surveying each high school, an effort was made to 
survey a representative sample of seniors. School personnel in each high school vouched that classes selected for the survey contalned a mix of academic achlevement levels for that high school. The classes surveyed at each high school were as follows:

$$
\begin{aligned}
& \text { Benson: Economics classes, 1st - 4th periods. } \\
& \text { Grant: Government classes, 1st and 2nd periods; } \\
& \text { Economics class, 3rd period; } \\
& \text { Psychology classes, 4th and } 6 \text { th periods. } \\
& \text { Lincoln: Writers workshop, 4th and } 7 \text { th periods; } \\
& \text { Humanities class, } 7 \text { th period. } \\
& \text { Madison: Government class, } 18 t \text { period. }
\end{aligned}
$$

As per conditions set forth by the portland state University Human subjects Review Committee, the survey instrument with an instruction sheet was handed out by the classroom teacher. The instruction sheet explained the nature of the survey and emphasized the voluntary nature of student participation (see Appendix $C$ ). The Human subjects Review Committee felt that the presence of the investigator in the classroom would be too coercive toward the students. Thus, the Investigator remained outside the classroom during the administration of the survey. It was decided that the inclusion of a cover sheet and absence of the investigator would provide anonymity and make completing the questionnaire less coercive.

A total of 372 questionnaires were returned to the 
investigator. Teachers reported that no students refusing to complete the questionnaire. Out of the total, fifty-five questionnaires were dropped from the sample because they were missing critical responses, l.e., failure to answer questions regarding attitude towards residential integration.

One problem with using survey data is that of knowing whether or not the respondent was sincere in his/her responses. Thurstone (1929) developed the test of response consistency to alleviate this problem. Thurstone's approach was to include multiple questions on the same topic. If a subject responded consistently to re-phrased forms of the same question, his/her response could be viewed as rellable. If a subject responded markedly differently to paraphrased forms of the same question, his/her response would be viewed as non-reliable and would be thrown out of the analysis.

Using Thurstone's technique, a second question regarding attitude toward residential racial integration was added to the survey. ${ }^{2}$ Two returned guestionnaires were thrown out of the analysis for extremely contradictory responses to the two questions on residential racial integration, l.e., the respondents strongly disagreed that Whites and non-Whites should live in the same neighborhood

\footnotetext{
The following question was added: "Non-Whites and Whites should live in the same neighborhood-blocks: strongly disagree, disagree, slightly disagree, slightly agree, agree, strongly agree."
} 
while expressing a preference to live in an extremely integrated neighborhood block.

The Einal sample contained 315 completed questionnaires (See Table VI). This sample represented 25 percent of the senior class enrollment in the four high schools surveyed. The final sample also constituted ten percent of the total 1986-87 senior class population of the Portland Public Schools.

TABLE VI

SAMPLE POPULATION COMPOSITION

\begin{tabular}{|c|c|c|}
\hline HLgh School & Samole & Rercent of senior class ${ }^{2}$ \\
\hline Madison & 38 & 168 \\
\hline Grant & $98^{2}$ & 298 \\
\hline Lincoln & $77^{2}$ & 238 \\
\hline Benson & 102 & 308 \\
\hline TOTALS & 315 & 258 \\
\hline
\end{tabular}

${ }^{2}$ Contains 3 Junior class students.

20ontains 15 junior class students.

'Source: 1986 Enrollment Report, Management Information Services, Portland Public schools, Portland, Oregon.

Non-Whites appear to be under-represented in the final sample (see Table VII). It is impossible to tell if this is 
actualiy the case since the school District does not report minority student composition by grade level within high schools. Therefore, it is not possible to compare the minority composition of the sample population with the sample universe of twelfth grade students in the four high schools selected for study.

Another reason for the disparity in minority composition may be due to the fact that the student population changes from the beginning to the end of the school year. Enrollment statistics are gathered in September, and the data for this study was collected in May. Between these dates, the student population at a given school can change maxkedly. For example, during the school year 1985-86, only 618 of students enrolled at Madison High school in the fall were still there in June (Portland Public Schools, 1986).

TABLE VII

SAMPLE POPULATION COMPARED TO SAMPLE UNIVERSE

Samole school District (All High School senoris) ${ }^{2}$

White $263(838) \quad 2,420(758)$

Non-White $\quad 52(178) \quad 801(258)$

$\begin{array}{lll}\text { TOTAL } & 315 & 3,221\end{array}$

'source: 1986 Enrollment Report, Management Information services, Portland Public schools, Portland, Oregon, p.p. 432 . 


\section{CHAPTER IV}

\section{DATA ANALYSIS AND RESULTS}

As previously stated, this dissertation concerns the social change potential of public education. School integration policies have been linked to the goal of bringing about a more integrated society. This study seeks to determine if there is a relationship between school integration experiences and student attitudes toward residential racial integration. If such a relationship exists, it would offer support for the contention that school integration can contribute to movement toward a more integrated society in the long-run. specifically, three hypotheses are to be tested:

1) Classroom racial composition (CRC) is positively related to behavioral attitude (BA) toward residential racial integration.

2) The onset of school integration (OSI) is positively related to behavioral attitude toward residential integration.

3) Involvement in racialiy integrated extracurricular activities (EA) is positively related to behavioral attitude toward residential racial integration.

All three aspects of the school integration experience, 
listed above, 1.e. CRC, OSI, and EA are thought to be positively related to attitude toward residential racial Integration. In order to test these hypotheses, the following regression model was employed: $B A=a+b_{2} C R C+$ $b_{2} O S I+b_{3} E A+b_{4} R A+b_{0} N R C+b_{4} P E B$

In addition to the hypothesized predictors, the potentially influential variables of race (RA), neighborhood racial composition (NRC), and parents' education background (PEB), are included to identify their relative effects on behavioral attitude toward residential racial integration (BA).

stepwise regression will be run to ldentify significant predictors included in the above regression model. The stepwise procedure will ldentify the variable that has the strongest linear association with attitude toward residential integration. This regression technique also Identifies subsequent variables that have a significant assoclation with BA while the effects of the other variables are controlled. This will allow a determination of the unique associatior of each predictor with attitude toward residential inteyration.

significant predictor varlables will be analyzed for multi-collinearity and functionality in their association with attitude toward residential racial integration. The analysis will begin with an examination of the descriptive statistics for each hypothesized variable. 


\section{Classroom Raclal Composition (CRC)}

Nearly the entire sample of students surveyed, 98 percent, reported having attended racially integrated classrooms at some time during their public school years (see Table VIII). This is a higher percentage than was expected given the diversity of PPS's racial composition. Less than two percent, all white students, reported having attended raclally segregated classrooms throughout their public school career. A good varlation in responses was obtained with this measure. All response categories except one had ten or more students.

TABLE VIII

CLASSROOM RACIAL COMPOSITION

\begin{tabular}{|c|c|c|c|c|}
\hline Response & & Value & Erequency & percent \\
\hline $\begin{array}{l}\text { Attended } \\
\text { classroom }\end{array}$ & $\begin{array}{l}\text { segregated } \\
\mathrm{ms}\end{array}$ & 1 & 5 & 1.68 \\
\hline $\begin{array}{l}\text { Attended } \\
\text { with 108 }\end{array}$ & $\begin{array}{l}\text { classrooms } \\
\text { other race* }\end{array}$ & 2 & 79 & 25.18 \\
\hline $\begin{array}{l}\text { Attended } \\
\text { with } 20 \%\end{array}$ & $\begin{array}{l}\text { classrooms } \\
\text { other race }\end{array}$ & 3 & 61 & 19.48 \\
\hline $\begin{array}{l}\text { Attended } \\
\text { with } 308\end{array}$ & $\begin{array}{l}\text { classrooms } \\
\text { other race }\end{array}$ & 4 & 69 & 21.98 \\
\hline $\begin{array}{l}\text { Attended } \\
\text { with } 46 \%\end{array}$ & $\begin{array}{l}\text { classrooms } \\
\text { other race }\end{array}$ & 5 & 32 & 10.28 \\
\hline $\begin{array}{l}\text { Attended } \\
\text { with } 50 \%\end{array}$ & $\begin{array}{l}\text { classrooms } \\
\text { other race }\end{array}$ & 6 & 16 & 5.18 \\
\hline
\end{tabular}


TABLE VIII

CLASSROOM RACIAL COMPOSITION

(continued)

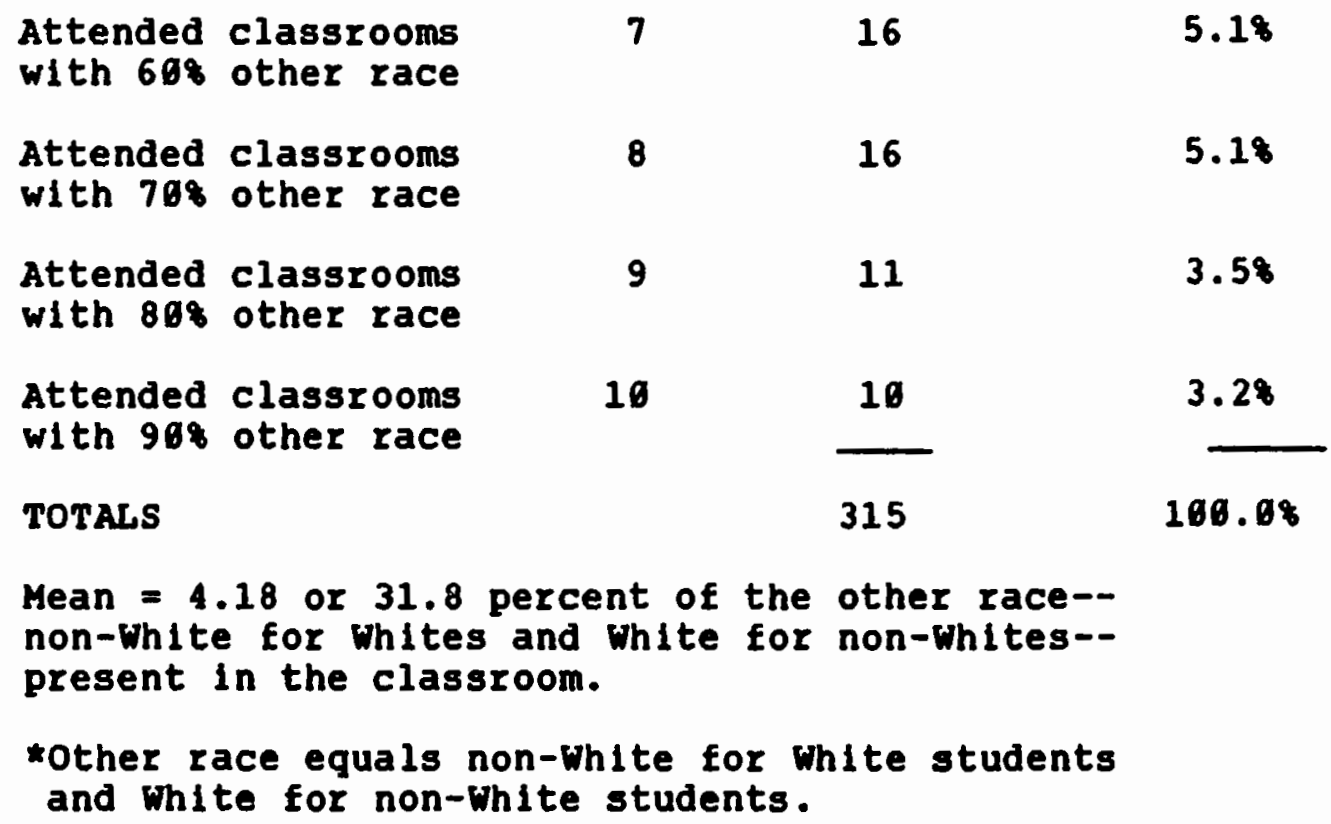

Broken down by race, the mean classroom racial composition was 76 percent own group and 24 percent other group for white students; 31 percent own group and 69 percent other group for Non-Whites (see Table IX). Both of these ratios are close to Portland Public school Districts' actual racial composition, 1.e. 73 percent white; 27 percent Non-White. As would be expected, Non-Whites scored slgnificantly higher than whites on this variable, with a mean score of 7.92 versus 3.44 . 
TABLE IX

CLASSROOM RACIAL COMPOSITION: FREQUENCY DISTRIBUTION BY RACE

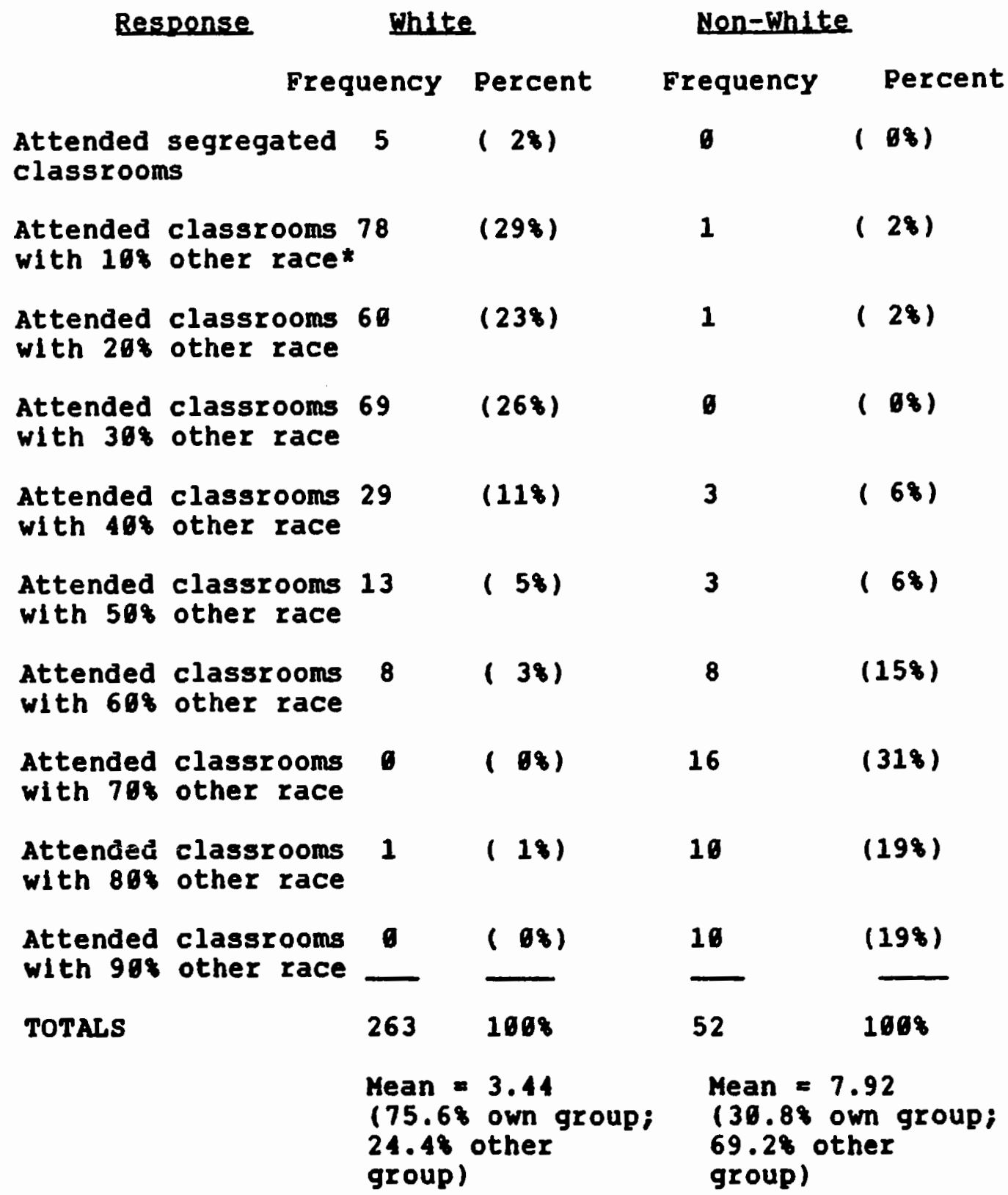


Onset of School Integration Experience (OSI)

Almost two-thirds, 66 percent, of the students surveyed reported being enrolled in integrated classrooms as early as kindergarten (see Table $X$ ). This is a remarkably high figure given the fact that 50 percent of Portland Public School's elementary schools had five percent or less nonWhite enroliment at the time the students surveyed were in the first grade in 1974 (Portland Public Schools, 1974). The high percentage of students experiencing school integration at the early grade levels indicates that nonWhite students were not segregated or grouped by classroom at the early grade levels. Johnson (1976) reported that Portland Public school District policy supported a conscious effort not to group Non-white students within classrooms during the early 1970s. This would account for the fact that, although many elementary schools had few Non-white students, they were spread out over many classrooms, thereby maximizing interracial contact.

Although most of the students reported experiencing school integration at the early grade levels, there was wide variation in reported onset of school integration. Onset of school integration was reported at every grade level except eleventh. More than ten students reported experiencing school integration for the first time at grades three, four and nine. 
TABLB $X$

ONSET OF SCHOOL INTEGRATION

\begin{tabular}{|c|c|c|c|}
\hline Response & Value & Erequency & Rercent \\
\hline Pre-kindergarten & 14 & 122 & 38.78 \\
\hline Kindergarten & 13 & 85 & 27.08 \\
\hline Flrst grade & 12 & 29 & 9.28 \\
\hline second grade & 11 & 6 & 1.98 \\
\hline Th1rd grade & 10 & 13 & 4.18 \\
\hline Fourth grade & 9 & 13 & 4.18 \\
\hline Fifth grade & 8 & 8 & 2.58 \\
\hline sixth grade & 7 & 11 & 3.58 \\
\hline Seventh grade & 6 & 3 & 1.08 \\
\hline Elghth grade & 5 & 5 & 1.68 \\
\hline Ninth grade & 4 & 15 & 4.88 \\
\hline Tenth grade & 3 & 2 & 0.68 \\
\hline Eleventh grade & 2 & $\boldsymbol{0}$ & 0.08 \\
\hline Twelfth grade & 1 & 2 & 0.68 \\
\hline $\begin{array}{l}\text { No Integration } \\
\text { Experience }\end{array}$ & 0 & 1 & 0.38 \\
\hline TOTALS & & 315 & 1008 \\
\hline
\end{tabular}

Mean $=11.83:$ Between First and Second Grade.

Involvement in Raclally Integrated Fxtracurricular Activities (BA)

A very hlgh percentage of the students surveyed, 86 percent, reported involvement in raclally integrated extracurricular activities. Most students participated in 
one or two activities whlle a few particlpated In as many as slx or seven extracurricular activities (see rable XI). The fact that only six percent of students did not participate in integrated extracurricular activities suggests that this behavior is somewhat normative. That is to say, participation in integrated extracurricular activities may be a non-differentlating factor with minor varlations in the case of the survey sample.

TABLE XI

INVOLVEHENT IN INTEGRATED

EXTRACURRI CULAR ACTIVITIES

Response

Did not participate

Did participate

No response

TOTALS
Erequency

19

270

26

315

Rercent

$$
6.08
$$

$85.7 \%$

8.39

100.08

Erequency

79

Rercent

Participated in one activity

Participated in two activities

86

22.28

Participated in three activities

57

27.38

Participated in four activities

40

18.18

Participated in five activities

11

12.78

Participated in $81 x$ activities

2

$3.5 \%$

Participated in seven activities

No response

15.28

TOTALS 
To summarize, the average student surveyed experienced racially integrated classrooms with racial compositions close to that of the District's racial composition. The average student also experienced school integration at an early grade level, l.e., by the second grade, and participated in one or two racially integrated extracurricular activities. Wide variation was obtained in classioom racial composition (CRC) and onset of school integration (OSI). On the other hand, relatively few students did not report participation in integrated extracuricular activities (EA) thus limiting variation on this measurement.

Behavioral Attitude Toward Residential Racial Integration (BA)

A remarkably high proportion of students surveyed, 93 percent, chose a racially integrated neighborhood in response to the residential choice question. Over half of the students, 64 percent, chose a neighborhood with 70 percent or less of their own race (see Table XII). This indicates a very high level of tolerance toward residential racial Integration compared to prior survey results. 
TABLE XII

BEHAVIORAL ATTITUDE TOWARD RESIDENTIAL RACIAL INTEGRATION

Response Value gre- $\begin{aligned} & \text { Per- } \begin{array}{c}\text { Cumula- } \\ \text { tive }\end{array} \\ & \text { cent }\end{aligned}$

\begin{tabular}{|c|c|c|c|c|}
\hline $\begin{array}{c}\text { Chose segregated } \\
\text { nelghborhood }\end{array}$ & 1 & 23 & 7.38 & 7.38 \\
\hline $\begin{array}{l}\text { Chose neighborhood } \\
\text { with } 908 \text { own race }\end{array}$ & 2 & 47 & 14.98 & 22.28 \\
\hline $\begin{array}{l}\text { Chose neighborhood } \\
\text { with } 808 \text { own race }\end{array}$ & 3 & 43 & 13.78 & 35.98 \\
\hline $\begin{array}{l}\text { Chose nelghborhood } \\
\text { with } 708 \text { own race }\end{array}$ & 4 & 34 & 10.88 & 46.78 \\
\hline $\begin{array}{l}\text { Chose neighborhood } \\
\text { with } 608 \text { own race }\end{array}$ & 5 & 25 & 7.98 & 54.68 \\
\hline $\begin{array}{l}\text { Chose neighborhood } \\
\text { with } 508 \text { own race }\end{array}$ & 6 & 116 & 36.88 & 91.48 \\
\hline $\begin{array}{l}\text { Chose neighborhood } \\
\text { with } 408 \text { own race }\end{array}$ & 7 & 4 & 1.38 & 92.78 \\
\hline $\begin{array}{l}\text { Chose nelghborhood } \\
\text { with } 308 \text { own race }\end{array}$ & 8 & 11 & 3.58 & 96.28 \\
\hline $\begin{array}{l}\text { Chose nelghborhood } \\
\text { with } 208 \text { own race }\end{array}$ & 9 & 4 & 1.38 & 97.58 \\
\hline $\begin{array}{l}\text { Chose neighborhood } \\
\text { with } 108 \text { own race }\end{array}$ & 16 & 8 & 2.52 & 100.08 \\
\hline TOTALS & 315 & 10 & & \\
\hline
\end{tabular}

In 1968, DeBerry and Agger surveyed 310 white and 62 Black adults in Portland as part of the Portland public School District's study on "Race and Education." While 91 percent of the Blacks surveyed felt they (Blacks) ought to 
live in racially integrated neighborhoods, only 45 percent of the Whites surveyed felt that Blacks should live in integrated neighborhoods. Forty-five percent of the whites felt that Blacks should live in segregated nelghborhoods; the remaining ten percent were undecided.

A more recent survey conducted by the Portland Housing Integration Task Force (1983) revealed that 56 percent of Portland's adult population would prefer to live in an "Integrated neighborhood containing both Blacks and Whites." This survey was based on a sample of 269 whites and 63 Blacks randomly selected from the phone book. Both of these earlier surveys indicate attitudes less favorable toward residential racial integration than those of students in this study. This suggests that students graduating from high school may be more prone to live in integrated neighborhoods than their parents.

The positive attitude toward racially integrated nelghborhoods was strong for both white and non-White students surveyed. Ninety-one percent of the white students chose a racially integrated neighborhood as their nelghborhood of preference. All the non-white students in the sample chose an integrated neighborhood (see Table XIII). 
TABLE XIII

BEHAVIORAL ATTITUDE TOWARD

RESIDENTIAL RACIAL INTEGRATION

FREQUENCY DISTRIBUTION BY RACE

\begin{tabular}{|c|c|c|c|c|c|c|c|}
\hline \multirow{2}{*}{\multicolumn{2}{|c|}{ Value }} & \multicolumn{4}{|c|}{ White } & \multirow{2}{*}{$\frac{\text { Non-White }}{\text { Erequency }}$} & \multirow[b]{2}{*}{ Bercent } \\
\hline & & & & equency & Percent & & \\
\hline 1 & (Seg) & regat & ted) & 23 & $(98)$ & $\theta$ & $(68)$ \\
\hline 2 & 1908 & own & group ) & 47 & $(188)$ & $\theta$ & $(08)$ \\
\hline 3 & 1868 & own & group) & 41 & (168) & 2 & $(48)$ \\
\hline 4 & 1708 & own & group) & 34 & $(138)$ & $\theta$ & $(08)$ \\
\hline 5 & 1688 & own & group) & 24 & $(98)$ & 1 & $(28)$ \\
\hline 6 & 1508 & own & group) & 89 & $(338)$ & 27 & $(528)$ \\
\hline 7 & 1498 & own & group) & 1 & $(<18)$ & 3 & $(6 \%)$ \\
\hline 8 & 1308 & own & groupl & 2 & $(18)$ & 9 & $(178)$ \\
\hline 9 & 1288 & own & group ) & 1 & $(<18)$ & 3 & $(68)$ \\
\hline 10 & $110 \%$ & own & group & 1 & $\mid\langle 13|$ & 1 & $(138)$ \\
\hline \multicolumn{2}{|c|}{ TOTALS } & & & 263 & 1008 & 52 & 1008 \\
\hline \multicolumn{5}{|c|}{$\begin{array}{l}\text { Hean }=4.08 \\
(69.2 \% \text { own group; } \\
30.8 \% \text { other group) }\end{array}$} & \multicolumn{2}{|c|}{$\begin{array}{l}\text { Mean }=6.98 \\
(40.28 \text { own group: } \\
59.88 \text { other group) }\end{array}$} & \\
\hline
\end{tabular}

The most frequent response on the neighborhood choice question was 50 percent own race/50 percent other race. This was true for whites and non-Whites. This may Indicate that students surveyed viewed real residential integration as consisting of neighborhoods with an equal proportion of Whites and Non-Whites. 
Non-Whites scored significantly higher on the behavioral attitude scale than Whites. That is to say, NonWhites consistently chose more racially integrated nelghborhoods than whites in response to the residential choice question. The average non-white chose a neighborhood with 60 percent other race (white) present while the average White chose a neighborhood with 31 percent of the other race (non-White) present. This finding is consistent with the earlier survey conducted in Portland by DeBerry and Agger (1968) in that non-whites are more tolerant and accepting of Whites in their neighborhoods than are whites of non-Whites. On the other hand, it appears that whites have experienced greater attitudinal change since the DeBerry and Agger survey, 1.e. 91 vs. 45 percent in favor of racially integrated neighborhoods.

MULTIPLE REGRESSION ANALYSIS

As stated earlier, the regression model used for testing hypotheses on the linear assoclation between school Integration experiences and attitude toward residential integration is $B A=a+b_{2} C R C+b_{2} O S I+b_{2} E A+b_{1} R A+b_{9} N R C$ + b. $P E B+$ e. A stepwise multiple regression analysis was conducted to determine significant predictors contained in this model. In this procedure, the first varlable considered for entry into the equation is the one with the 
largest positive or negative linear correlation with the dependent varlable, 1.e. behavior attitude toward residential racial integration. subsequent predictors are then selected for entry based on their partial correlation with the dependent varlable, l.e. hlghest partial correlation to statistically significant (.05 level) lowest correlation coefficlent. The results of this analysis are depicted in Table XIX.

\section{TABLE XIV}

MULTIPLE REGRESSION ANALYSIS OF VARIATION IN ATTITUDE TOWARD RESIDENTIAL INTEGRATION: STEPWI SE REGRESSION

Variable entered on step one: Race

$$
\begin{array}{ll}
\text { Multlple R } & .4951 \\
\text { R Squared } & .2452
\end{array}
$$

Varlable entered on step two: Racial composition of school

$$
\begin{array}{ll}
\text { Multiple R } & .5576 \\
\text { R squared } & .3163
\end{array}
$$

Varlable entered on step three: Onset of school Integration

$$
\text { Multiple R } .5933
$$$$
\text { R Squared } .3520
$$

Varlable entered on step four: Neighborhood racial composition

$$
\begin{array}{ll}
\text { Multlple R } & .6668 \\
R \text { squared } & .3681
\end{array}
$$

Varlable entered on step five: Parents' educational background

$$
\begin{array}{ll}
\text { Multiple R } & .6156 \\
R \text { squared } & .3790
\end{array}
$$

Multiple $R \quad .61848$ standard Error 1.6656

$R$ square $\quad .38252 \quad F=24.51$ (Significant at .00 level) 
The stepwise multiple regression showed race as having the strongest association with behavioral attitude toward residential racial integration (BA), 1.e. $r^{2}=.25$. The second and third strongest predictors of $B A$ were racial composition of the school (SCH), $\mathrm{r}^{2}$ increased to .31 , and onset of school integration experience (OSI), $r^{2}$ increased to .35. Nelghborhood raclal composition (NRC) and parents' education background (PEB) rounded out the group of variables that added to the overall variation in BA accounted for through statistically significant associations. Total variance in BA scores accounted for by this regression model is 38 percent.

An examination of partial correlations and beta weights generally supports the results of the regression coefficlents (see Table XV). Race (RA) and School racial composition (SCH) show up as having the strongest association with $\mathrm{BA}$ when the 1 inear effects of the other predictors are removed: partial $I=-.29$ and -.31 respectively. The onset of school integration (OSI), nelghborhood racial composition (MRC), and parents' educational background (PEB) follow in significance with partial rs of $.25, .16$, and -.13 respectively. 
TABLE XV

MULTIPLE REGRESSION ANALYSIS OF VARIATION

IN ATTITUDE TOWARD RESIDENTIAL INTEGRATION:

PARTIAL CORRELATIONS AND BETA WEIGHTS

\begin{tabular}{|c|c|c|c|c|}
\hline PREDICTOR & $\begin{array}{c}\text { PARTIAL } \\
\text { CORRELATION }\end{array}$ & $\begin{array}{l}\text { S I GNIF I CANCE } \\
\text { LEVEL }\end{array}$ & BETA & $\begin{array}{l}\text { SI GN I I I CANCE } \\
\text { LEVEL }\end{array}$ \\
\hline $\begin{array}{l}\text { NRC (Neigh. } \\
\text { Raclal Comp.) }\end{array}$ & .16 & .0073 & .1807 & .9073 \\
\hline $\begin{array}{l}\text { EA (Invol. In } \\
\text { Racial Int. } \\
\text { Extra Curic. Act }\end{array}$ & $\begin{array}{l}-.07 \\
-t .1\end{array}$ & .2320 & -.0567 & .2320 \\
\hline $\begin{array}{l}\text { sCH (Sch. Racial } \\
\text { Composition) }\end{array}$ & $21-.31$ & .0000 & -.2612 & .0000 \\
\hline $\begin{array}{l}\text { OsI (Onset sch. } \\
\text { Int.) }\end{array}$ & $\cdot .25$ & .0000 & -.2620 & .0000 \\
\hline $\begin{array}{l}\text { PEB (Parents Ed. } \\
\text { Background) }\end{array}$ & $1 .-.13$ & .0317 & -.1042 & .0317 \\
\hline $\begin{array}{l}\text { CRC (Classroom } \\
\text { Ra Composition) }\end{array}$ &.- .02 & .7345 & -.0260 & .7345 \\
\hline RA (Race) & -.29 & .0000 & -.3926 & .0000 \\
\hline
\end{tabular}

The standardized partial slope estimates, or beta weights, also confirm the regression analysis with change in RA being assoclated with the largest change in BA followed by SCH, OSI, NRC, and PEB respectively.

only one of the hypothesized linear associations appears to be significant. The onset of school integration (OSI) is significantly associated with behavioral attitude (BA) toward residential racial integration. classroom racial composition (CRC) and involvement in integrated extracurricular activities (EA) do not appear to have 
signiflcant linear associations with BA.

Although it was not one of the hypothesized predictors, the racial composition of the school (SCH) turned out to have a significant linear relationship with BA. Racial composition of the school was measured by the proportion of Non-White students. The higher the percentage of Non-White students, the more negative were student attitudes toward residential integration. This result needs to be interpreted with caution since only four cases (or schools) were included in the analysis. Varlation on this measure was $11 \mathrm{mited}$ with values of $16,39,34$, and 35 percent NonWhite students.

All three antecedent variables were significantly associated with behavioral attitude toward residential integration. As mentioned above, race had the strongest linear association of all the predictors considered. This result was suggested by the analysis of descriptive statistics. Earlier in this chapter it was reported that the average behavioral attitude score for whites was 1.98 while the same score for Non-Whites was 6.98. This is a rather large discrepancy glven the range of measurement, 1.e. one to ten scale. The results of both the descriptive and regression analysis indlcate that behavioral attitude toward residential racial integration is significantly different for whites and Non-Whites.

Neighborhood racial composition (NRC) also had a 
significant association with attitude toward residential integration. The higher the level of neighborhood integration, the more positive the attitude toward residential integration. The direction of this relationship was predicted by prior research discussed in Chapter Two.

Finally, the antecedent variable of parents' educational background (PEB) was found to have a significant association with BA. Although this relationship was anticipated from prior research, its direction was the opposite of what was expected. A negative relationship was found to exist between PEB, as measured by whether or not a student's parent(8) graduated from college, and BA. Prior studies suggested a positive association. The observed association was not strong, 1.e. significant at . 3 level. Also, the variation in PEB was limited to a nominal categorization.

The negative association obtained on the relationship between PEB and BA somewhat strengthens the finding of a positive relationship between $O S I$ and $B A$. That is to say, a positive relationship between school integration experience, 1.e. OSI, and attitude toward residential integration was found with the absence of positive support for more highly educated, liberal family backgrounds.

One of the major problems with multiple regression analysis is that of multi-collinearity. When the independent variables or predictors in a given model are 
highly correlated, it is difficult to arrive at a judgment of their relative strength of association with the variable being predicted. In the case of the present regression model, it could be surmised that multi-collinearity is a problem. The school integration variables, as well the antecedent factors, could be intercorrelated. For example, it is reasonable to assume that race, onset of school Integration, and parents' educational background might be correlated. In Portland, oregon, if a student is Non-White, he/she is likely to encounter school integration early and have parents with a lower educational background than if he/she is white.

Perhaps the best way to detect multi-collinearity is to regress each Independent varlable on all the other independent varlables (Lewis-Beck, 1989). When any of the $R^{2} s$ from these equations is near 1.6, high multicollinearity is indicated. Using the SPssPc statistical package, tolerance coefficients $\left(1-R^{2}\right)$ were calculated for each predictor variable in the model (see Table XVI).

TABLE XVI

MULTI-COLLINEARITY AMONG PREDICTORS:

TOLERANCE COEFFICIENTS

\begin{tabular}{|c|c|c|}
\hline PREDICTOR & $\begin{array}{l}\text { TOLERANCE } \\
\text { COEFEICIENT }\end{array}$ & $\begin{array}{c}\text { COEFFICIENT } \\
\text { OE MULTI- } \\
\text { DETERMINATION }\end{array}$ \\
\hline $\begin{array}{l}\text { NRC (Neighborhood } \\
\text { Racial Composition) }\end{array}$ & .499 & .501 \\
\hline
\end{tabular}


TABLE XVI

MULTI-COLLINEARITY AMONG PREDICTORS:

TOLERANCE COEFEICIENTS

(Continued)

\section{PREDICTOR}

TOLERANCE

COEFE I CI ENT
COEFEICIENT

OF MULTI -

DETERMINATION

$\begin{array}{lll}\text { EA (Involvement In } & .992 & \\ \begin{array}{l}\text { Racial Integration } \\ \text { Extracurricular Activities) }\end{array} & & .608 \\ \begin{array}{l}\text { SCH (School Racial } \\ \text { Composition) }\end{array} & .979 & .621 \\ \begin{array}{l}\text { OsI (Onset School } \\ \text { (Integration) }\end{array} & .976 & .024 \\ \begin{array}{l}\text { PEB (Parents' Educational } \\ \text { Background) }\end{array} & .958 & .042 \\ \begin{array}{l}\text { CRC (Classioom Racial } \\ \text { Composition) }\end{array} & .379 & .621 \\ \text { RA (Race) } & & .644\end{array}$

Most of the tolerance coefflcients were very high, 1.e. over 9, Indicating little, if any, multi-collinearity. The largest coefficient of multiple determination, $R^{2}=.64$, was obtained for race. As mentioned above, this was to be expected. With regard to the hypothesized school Integration variables, 1.e. CRC, OSI, and EA, none were found to have high multi-collinearity with other predictors. Thus far, the additive effects of the predictor varlables have been considered. The question now arises, "Is the association of any predictor variable with behavioral attitude toward residential integration dependent 
on the value of another predictor varlable?" In order to determine interaction effects, the values of significant predictor variables were multiplied with each other to create ten new "interaction" variables. A forced multiple regression analysis was then run with all the interaction variables in addition to the significant predictors obtained from the stepwise regression (See Table XVII).

TABLE XVII

INTERACTION EFEECTS OF PREDICTORS

ON BEHAVIORAL ATTITUDE

PREDICTOR

RA

SCH

SCH X NRC

RA X OSI*

NRC

RA X PEB

OSI

NRC $X$ PEB

SCH $X$ OsI

SCH X PEB

OSI X PEB

RA X NRC

OSI X NRC

RA $X \mathrm{SCH}$
BETA

$-1.29$

$-.67$

.75

.66

$-.78$

.29

$-.34$

.11

.27

$-.24$

$-.17$

.08

.16

.23
SIGNI FI CANCE

LEVEL

.6024

.0173

.0114

.0223

.0584

.1476

.2099

.2753

.3122

.3478

.4397

.4636

.5256

.5437 
TABLE XVII

INTERAC'IIUN EF'ECTS OF' PREDICTORS

ON BEHAVIORAL ATTITUDE

(Cont inued)

PED Tolerance level exceeded, NOT entered into equation. Multiple $\mathrm{R}=.65726 \quad$ standard Error $=1.65$

$\mathrm{R}$ Squared $=.4321$

*signiticant lnteraction kitects

The results of the interaction analysis indicate two significant (.05 level) tunctional relationhships. The relationship between the onset of school integration experience and behavioral attitude toward residential racial integration is a function of race. The relationship between OSI and $B A$ is significant for white students and insignificant for Non-White students. This finding is further depicted in Figure 1.

The other significant functional relationship was that between neighborhood racial composition and school racial composition. The relationship between neighborhood racial composition and behavioral attitude toward resiuential racial integration appears to be dependent on school racial composition. The relationship between NRC and BA is significant for schools with higher Non-White compositions and not significant for schools with lower Non-White compositions. This finding is further illuminated in Figure 2. It should be noted, however, that the variation in 
73

school racial composition is restricted to four cases.

The results of the multiple regression analyses suggest

the following model: $\quad B A=a+b_{2} R A+b_{2} S C H+b_{3}$ OS $+b_{4}$ NRC

$+b_{s} P E B+e$. OE the three hypothesized school integration

factors, only the onset of school integration demonstrated a

significant linear association with attitude toward

residential racial integration. The relationships between

BA and the other school integration measures, 1.e. CRC and 


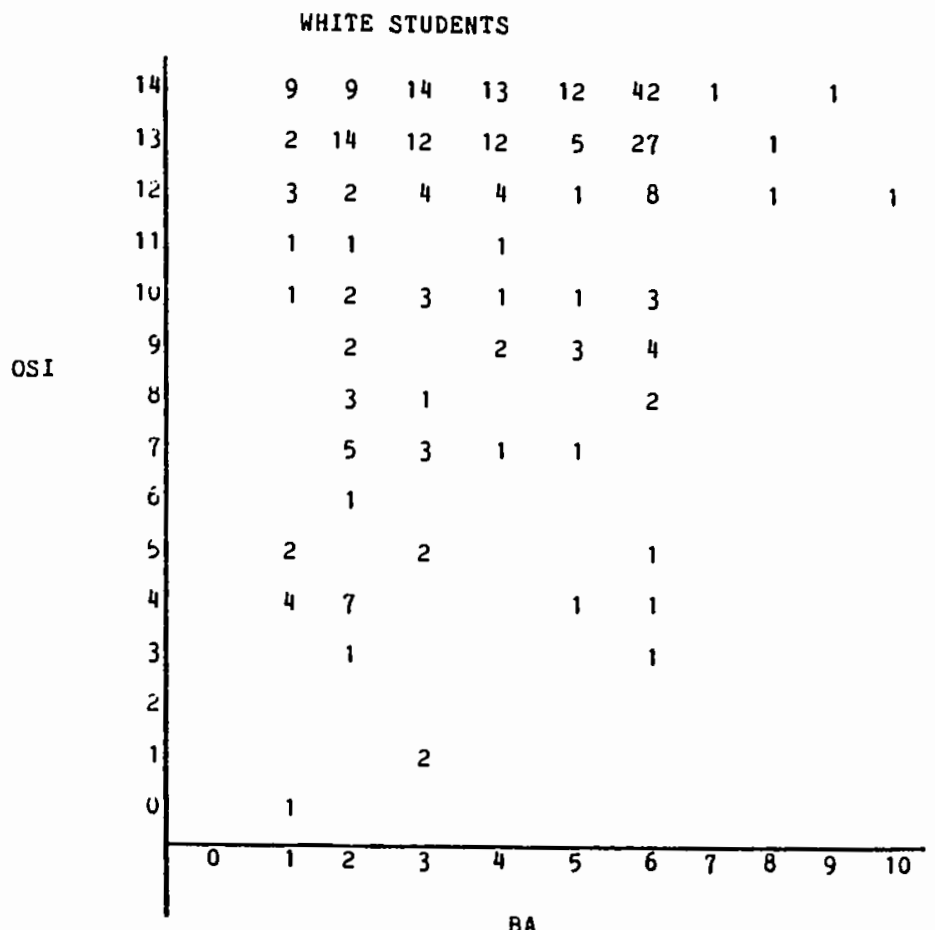

HON-WHITE STUDENTS

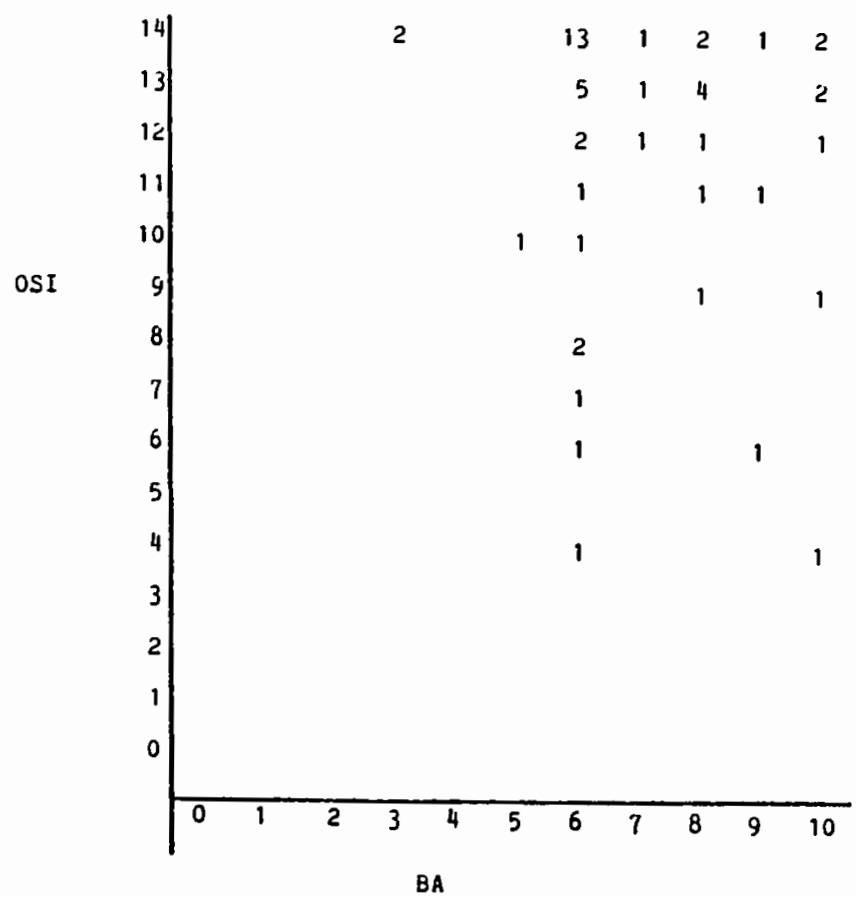

Flqure L. OSL X BA BY RA (Frequency scatter gram) 

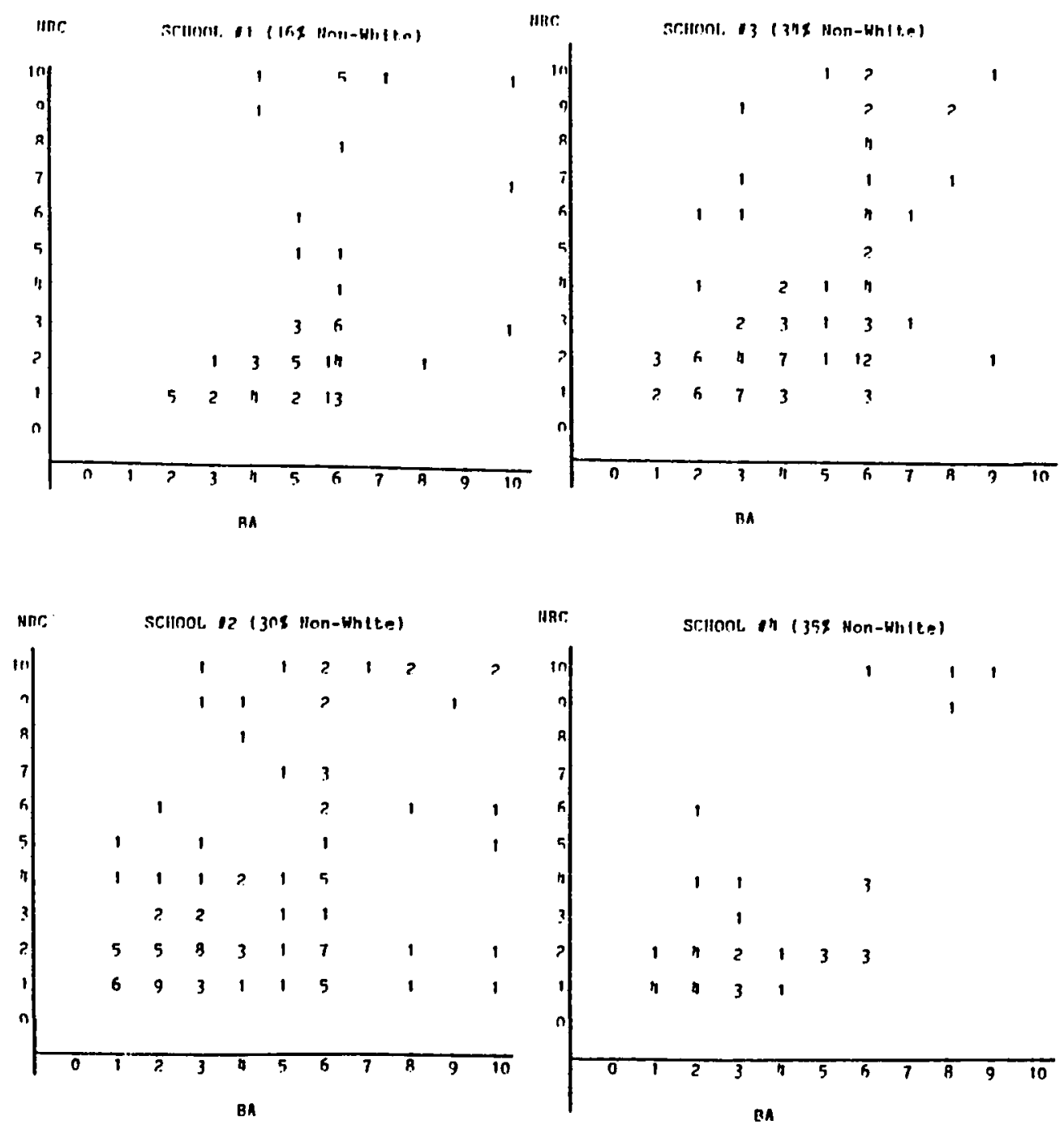

Elqure 2. NRC X BA BY SCH (Erequency scatter (jraii) 
EA were not strong enough to reject the null hypotheses. Onset of school integration, however, appears to account for a significant, unique amount of the overall variation in student attitude toward residential racial integration. 
CHAPTER $\mathrm{v}$

THEORETICAL AND POLICX IMPLICATIONS

The results of this study are both consistent and inconsistent with prevlous theory and research. First of all, this study establishes a direct association between school integration experience and student attitudes toward residential racial integration. This finding is consistent with previous research discussed in Chapter one that suggests there exists a positive relationship between school integration and an increase in residential racial integration (U.S. Commission on Civil Rights, 1967; Taeber, 1978; Orfle1d, 1978; Pearce, 1981; and Hawley, 1983). The present findings go beyond earlier studies and establish a direct relationship between the school integration experlence and residential choice attitudes of graduating high-school students. Furthermore, this study reveals that the onset of school integration is the one aspect of school integration experience that is significantly related to attitudes toward residential racial integration.

The results of the present research are inconsistent with previous theory and research that suggest the amount of interracial contact and involvement in racially integrated extra-curricular activities would be positively related to 
attitudes toward residential racial integration. Furthermore, the results indicate the relationship between school integration and attitude toward residential racial integration is different for minority and majority group members. These findings will now be considered as to their theoretical and policy implications.

\section{THE ONSET OF SCHOOL INTEGRATION AND STUDENT ATTITUDE TOWARD RESIDENTIAL RACIAL INTEGRATION}

The results of this study establish a direct relationship between school integration and residential racial integration. Prior research (U.S. Commission on Civil Rights, 1967; Orfleld, 1978; and Pearce, 1981) had asserted a direct linkage based on circumstantial evidence, e.g. school districts with desegregation plans appear to be experiencing gains in residentlal integration or persons that attended an integrated school report a higher tolerance toward racially integrated neighborhoods. However, the school integration experience had not been defined and directly linked to a propensity toward residential integration. The results of this study establish such a direct relationship. Furthermore, early onset of the school integration experience appears to be central to this relationship.

The positive association between the onset of school Integration and student attitudes toward residential 
integration is consistent with earlier research indicating that interracial contact at an early age will lead to greater Interracial acceptance and soclal preference (Allport, 1954, Goldstein et.al., 1979). Moreover, the present study indicates this effect endures into young adulthood and leads to positive attitudes toward residential racial integration. Other studies have not reported on such longitudinal effects. Rather, previous research measured attitude differences between children in segregated and integrated situations at the early grade levels, i.e. kindergarten and first grade.

The relationship between the onset of school Integration and attitude toward residential integration appears to be significant for the majority group only. Allport (1954) theorlzed that intergroup contact at an early age would lead to increased interracial tolerance among both minority and majority groups. The results of the present study suggest this is the case for the majority group but not the minority group. The relationship between the onset of school integration and attitude toward residential integration among non-whites was negative and statistically insignificant (Table XVIII).

since Allport's work, research on early-age interracial contact has focused on the reduction in negative stigma or stereotype associated with minority group membership. In summarizing this research, Goldstein (1979) notes a more 
positive attitude toward the minority group on both the part of majority and minority group members:

To varying degrees, then, all children in interracial classes exhibit more preference for and acceptance ot blacks, the traditionally devalued race, and less preference tor whites than did children in segregated classrooils. (Goldstein, 19\%9:93)

'I'ABLE XVIII

OSI AND BA CORRELATLON SUMMARY

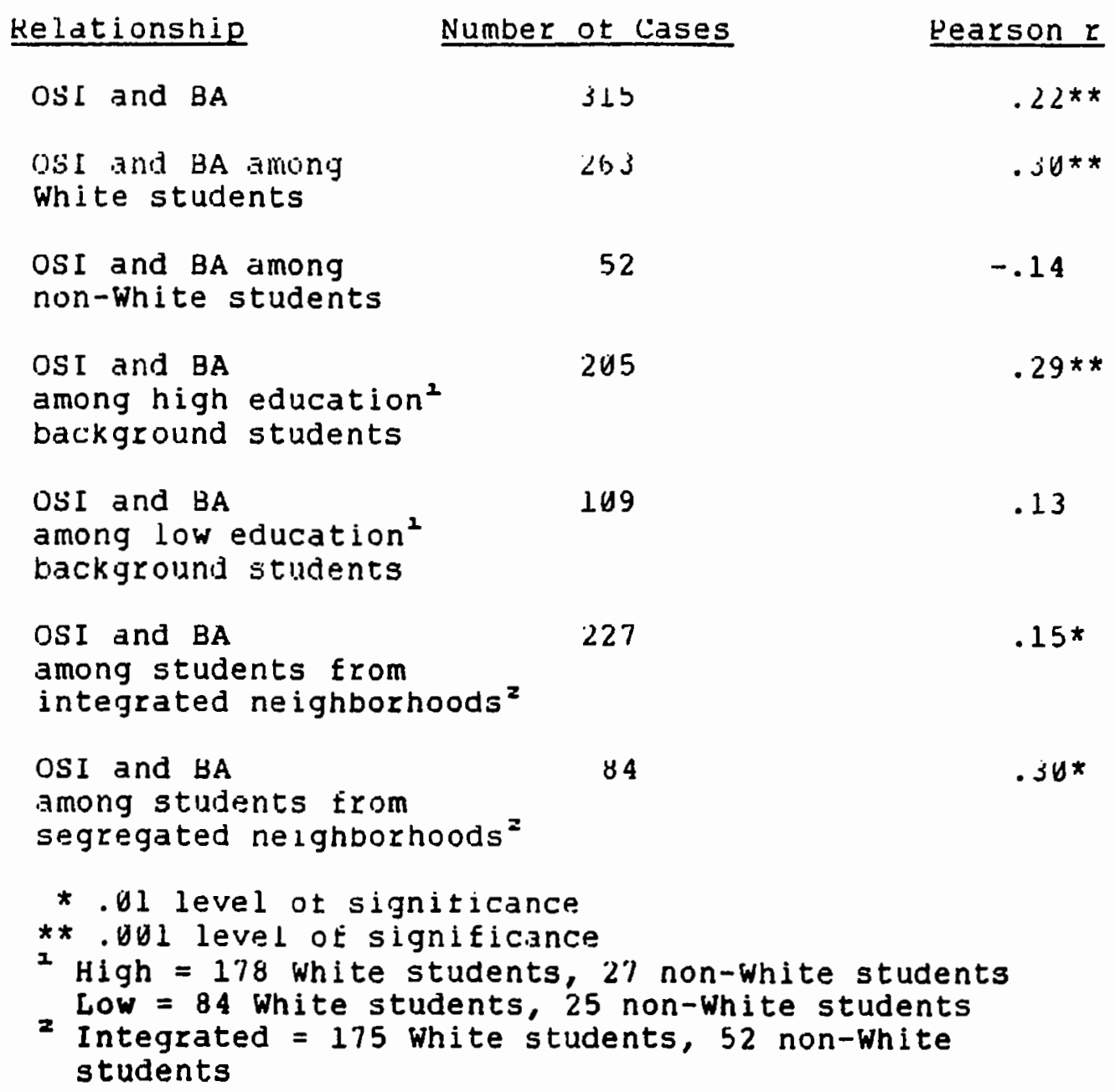




\title{
TABLE XVIII
}

\section{OSI AND BA CORRELATION SUMMARY (Continued)}

\begin{abstract}
Segregated $=84$ White students, $v$ non-White students
\end{abstract}
The present stady confirms Goldstein's finding in that early school integration experience is associated with a greater residential preference for Non-White neighbors among both the white and Non-White groups. This helps explain the negative correlation found between the onset of school integration and attitude toward residential racial integration found among the Non-white group. By expressing a residential preterence toward their own group, Non-whites recorded lower scores on the residential integration behavioral attitude scale. This contributed to a negative association between OSI and BA for Non-Whites.

The relationship between the onset of school integration and attitude toward residential integration was robust when taking into account the antecedent intluences of family educational background and neighborhood racial composition. This correlation remained positive for students with college and non-college educated parents. Most noteworthy was the finding that this positive relationship was statistically significant for students from both integrated and segregated neighborhoods (see Table XVIII). 
Previous research has indicated that neighborhood racial composition is a significant determinant of racial attitudes (Darden and parsons, 1981). This research has reported that white students from all-white neighborhoods have more negative attitudes toward raclal integration than White students from racially integrated neighborhoods. The results of the present study suggest that school integration at the early grade levels may counteract the lack of Interraclal contact at the neighborhood level. Such contact may foster a positive attitude toward residential racial integration in the absence of interracial contact at the neighborhood level.

Perhaps the most significant extrapolation from the finding that the onset of school integration is the key factor associated with student attitude toward residential integration is an explanation of why residential racial segregation has persisted desplte widespread school Integration. If early exposure to. Interracial contact is the main factor related to behavioral attitude toward residential racial integration, it would require an extended period of time for this relationship to impact residential cholce patterns. Early exposure to school integration at the kindergarten or first grade levels would take at least 12 years to influence residential choice, 1.e. when the student graduates from high school. If college or the military is involved in a student's career plans, it would 
take over 16 years for early school integration experience to affect residential cholce behavior. These estimates are probably conservative given the current climate of deferred home buying due to the high cost of housing. Given the fact that school integration policies were not widely prevalent until the mid-1960's, the impact of early grade level school integration experience on residential choice would not be evident until the 1989s. The 1980 census data do not reflect this impact.

As pointed out in Chapter Two, the primary determinants of residential choice are proximity to work, features of the dwelling, and financial considerations. Before school integration experience could be a factor in residential cholce, these other determinants must be somewhat constant. That is to say, one's preference for an integrated nelghborhood might come into play after his/her preference for work proximity, dwelling features, and financial attractiveness are met. If these conditions are not present in an integrated neighborhood, the influence of school integration experience is not likely to be a factor in residential cholce.

The findings of the present study also suggest that school Integration plans that do not involve the early grade levels may have a negligible impact on student attitudes toward residential integration and, thus, also have an insignificant impact on subsequent residential racial 
patterns.

with regard to the site for this study, Portland, Oregon, a concerted effort was initially made to integrate early grade levels through the creation of Early childhood Centers in the Black community. As discussed in Chapter Une, this policy, along with the recruitment of black students to attend predominately white schools outside their neighborhoods, resulted in a significant increase in racial integration at the early grade levels (See Table XIX).

\section{T'ABLE' XIX}

MINORITY ENROLLMEN'T TRENDS:

PERCENT MINORI'Y'Y ENROLLME'N'

$\begin{array}{llll}\text { SCHOOL* } & 1968 & 1986 & 1986 \\ \text { HUMBOLT } & 928 & 398 & 898 \\ \text { KING } & 948 & 598 & 718 \\ \text { SABIN } & 538 & 498 & 578 \\ \text { AVERAGE } & 798 & 498 & 728\end{array}$

*These schools were chosen because they have consistently remained designated as Early Childhood Centers throughout the period of Portland's school Integration Policy.

However, as also mentioned in Chapter one, the portland School District's emphasis on a voluntary school integration approach resulted in an end to the policy ot recruiting minority students to leave their neighborhoods and attend 
elementary schools elsewhere in the district. A new middle school was opened in the Black Community in 1982 to allow Black residents the opportunity to attend school closer to home. A concomitant increase in effort to recruit White students into the elementary schools in the Black Community did not occur or did not offset the re-segregation caused by the discontinuance of minority recruitment to predominantly White elementary schools (See Table XIX).

As documented in Chapter One, Portland's school integration policy has included residential racial integration as both an implicit and an explicit policy goal. The results of the present study suggest this policy is being undermined by a concurrent policy of maximizing individual cholce and a de-emphasis of minority recruitment from home neighborhood schools. This latter policy has resulted in a reduction of interracial contact at the early grade levels. The current study indicates that reduced interracial contact at the early grade levels will weaken the relationship between school integration and residential racial integration in Portland, Oregon.

In addition to OSI, the racial composition of the school (SCH) was found to be significantly associated with attitude toward residential racial integration. Although the variability on this predictor was limited, the finding merits discussion. Allport (1954) theorized that the larger the ratio of "incoming minority" to resident population, the 
greater the probability for conflict. Subsequent1y, Douglas (1982) has speculated that when racial compositions of schools are over 408 minority, whites develop negative attitudes toward racial integration. While no school in the present study had a minority composition of over 40\%, minority racial composition was negatively associated with attitude toward residential integration among white students. Studies that include more cases and variability on the school racial composition factor are needed to clarify this relationship and more precisely determine its effects relative to OSI.

\section{OTHER ASPECTS OF SCHOOL INTEGRATION EXPERIENCE AND STUDENT ATTITUDE TOWARD RESIDENTIAL RACIAL INTEGRATION}

Interracial contact as measured by classroom racial composition does not appear to be significantly associated with behavioral attitude toward residential racial integration. This finding is contrary to Allport's (1954) theory that interracial contact under certain conditions is positively associated with interracial sociometric preference. All of Allport's conditions for a positive relationship appear to be met by the school integration setting, i.e. equal status: 1) both groups have student status; 2) schooling is an ordinary purposeful pursuit; and 3) school integration has institution sanction. However, in the present study, these conditions did not 
produce a positive relationship between interracial contact as measured by classroom racial composition and attitude toward residential raclal integration.

Since Allport's work, studies on the relationship between school integration and interracial attitudes have revealed mixed results. After reviewing research on the results of the first fourteen years of school integration policy , 1954-1970, Carithers (1970) concluded that interracial contact did not consistently bring about increased tolerance or acceptance of Blacks by Whites. st. John (1975) reviewed 41 studies on the effects of school-age interracial (Black/White) contact on racial prejudice and noted that:

Sometimes desegregation is reported to have ameliorated the prejudice of whites but intensified that of blacks, sometimes the reverse (st. John, 1975: 67-68).

More recently, Patchen (1982), Rossell and Hawley (1983), and Prager et. al. (1986), have confirmed that interracial contact in schools is a varied and complex phenomenon that does not render any consistent social outcomes. Consequently, the fact that interracial contact, as measured by classroom racial composition, was not significantly related to attitude toward residential integration in this study is not surprising. Rather, it supports an emerging consensus that interracial contact per-se does not, and will not, increase interracial social preference. 
Thus, the current study as well as the reviews of literature cited above, indicate that the policy goal of societal racial integration will not be achieved by school integration as measured by the extent of interracial contact. The assumption that bringing majority and minority children together in schools will change the negative racial attitudes they acquire from family and community is not supported. If school integration has, or will have, a positive relationship to societal integration, i.e. residential integration, such a relationship has, or will, be founded on experiences other than the amount of interracial contact.

Contrary to previous theory and research, data from the present study did not reveal a significant relationship between participation in racially integrated extracurricular activities and behavior attitudes toward residential integration. Both Allport (1954) and Myrdal (1944) theorized that interracial contact in the context of "team work" and "cooperative endeavors" would reduce prejudice and improve attitudes toward the other race. The present study hypothesized that such contact occurs when white and NonWhite students participate in extracurricular activities together, e.g. athletics, school clubs. If this supposition was correct, the results of this study did not confirm previous theory.

Failure to obtain a significant relationship between 
participation in racially integrated extracurricular activities and attitude toward residential racial integration also casts doubt on previous research that supports such a relationship. Crain (1981) reported that Black and White students in high schools with a high extracurricular activity participation rate, 1.e.80\% or more of student body are participants, were more likely to have opposite-race friends than students attending schools with a low participation rate, l.e. less than 50\% of students participate in extracurricular activities. Crain Interpreted these results as supporting the existence of a relationship between participation in racially integrated extracurricular activities and positive interracial attitudes.

Crain's study, however, has two major weaknesses. First, other potentially significant factors, 1.e. onset of school integration, family background, and neighborhood racial composition, were not controlled for between high and low extracurricular participation schools. Second, the racial composition of extracurricular activity groups was not taken into account. Both of these weaknesses $11 \mathrm{mit}$ Crain's ablilty to assert a relationship between participation in racially integrated extracurricular activities and racial attitudes.

The relationship between participation in racially integrated extracurricular activities and racial attitudes 
remains unclear. The present study falls to offer support for this relationship. If such a relationship exists, it is likely to be based on the nature of interracial contact that takes place in the extracurricular activity. Like the research on interracial contact in a school setting, interracial contact in an extracurricular activity setting may have widely varying effects on racial attitudes. These effects are based on something other than mere interracial contact in a generally similar environment.

In summary, the present study clearly indicates that Interracial contact at the early grade levels can contribute to the policy goal of societal racial integration. On the other hand, mere interracial contact, at any grade level in a school environment, appears not to be associated with racial attitudes and, therefore, is probably not related to societal racial integration, 1.e. attitude toward residential racial integration. This latter finding was extended to include the sub-school environment of extracurricular activities.

THE RELATIONSHIP BETWEEN SCHOOL INTEGRATION AND ATTITUDE TOWARD RESIDENTIAL RACIAL INTEGRATION: DIFFERENTIAL RESULTS FOR MINORITY AND MAJORITY GROURS

The results of this study indicate a differential effect of school integration on the minority and majority groups. Table XXI suggests that increased exposure to NonWhites among whites, through school integration, increases 
the preference for Non-whites in a residential setting. On the other hand, this table also reveals that such exposure seems to have little or no affect on Non-White preference for whites in a neighborhood setting.

In general, the present study reveals that white students were exposed to more Non-Whites in school than their neighborhoods and desired to live in neighborhoods that have proportionately more Non-white than do either their current neighborhoods or school classrooms. On the other hand, Non-white students were exposed to a slightly higher proportion of Whites in school than in their neighborhoods, and they seek to live in neighborhoods with slightly fewer Whites than either their current nelghborhoods or classrooms.

TABLE XXI

COMPARISON OF WHITE AND NON-WHITE

MEAN NRC, CRC, AND BA SCORES

\begin{tabular}{|c|c|c|c|}
\hline $\begin{array}{l}\text { RACIAL } \\
\text { GROUP }\end{array}$ & $\begin{array}{c}\text { MEAN } \\
\text { NEIGHBORHOOD } \\
\text { RACIAL COMPOSITION } \\
\text { SCORE }\end{array}$ & $\begin{array}{l}\text { MEAN } \\
\text { CLASSROOM } \\
\text { COMPOSITION } \\
\text { SCORE }\end{array}$ & $\begin{array}{l}\text { MEAN } \\
\text { BEHAVIORAL } \\
\text { ATTITUDE } \\
\text { SCORE }\end{array}$ \\
\hline \multirow[t]{2}{*}{ WHITE } & 2.5 & 3.4 & 4.1 \\
\hline & $\begin{array}{l}\text { (Equals } 858 \\
\text { White; } 158 \\
\text { Non-White) }\end{array}$ & $\begin{array}{l}\text { (Equals } 758 \\
\text { White; } 25 \% \\
\text { Non-White) }\end{array}$ & $\begin{array}{l}\text { (Equals } 698 \\
\text { White; } 318 \\
\text { Non-White) }\end{array}$ \\
\hline \multirow[t]{2}{*}{ NON-WHITE } & 7.6 & 7.9 & 7.0 \\
\hline & $\begin{array}{l}\text { (Equals } 668 \\
\text { White; } 348 \\
\text { Non-white) }\end{array}$ & $\begin{array}{l}\text { (Equals } 698 \\
\text { White; } 318 \\
\text { Non-White) }\end{array}$ & $\begin{array}{c}\text { (Equals } 608 \\
\text { white } 468 \\
\text { Non-White) }\end{array}$ \\
\hline
\end{tabular}


TABLE XXI

COMPARISON OF WHITE AND NON-WHITE

MEAN NRC, CRC, AND BA SCORES

(Continued)

*Racial Composition of the City: 878 White; 138 Non-White. **Racial Composition of School District: 758 white; 258 NonWhite.

The differential results for minority and majority groups obtained in this study have interesting policy implications. As described earlier, the policy of school integration originated with the landmark supreme court decision of Brown $v$. Board of Education. The focus of this decision and subsequent school integration policy has been that of improving educational opportunity for minority students. Thus, the policy goals of school integration have centered on changes in minority students, e.g. improved academic performance, higher self-esteem. The results of the present study suggest that the impact of school integration policy, at least in the area of interracial relations, is more significant for the majority group. Specifically, school integration appears to have an impact on majority, as opposed to minority group attitudes toward residential racial integration.

The big question of, "To what extent will school integration bring about a more integrated society?", remains largely unanswered. The present study clearly indicates that early school integration experience is related to 
positive attitude toward residential racial integration among White students. To this extent, school integration can be viewed as contributing to the "accommodation" of minorities by the majority group. Allport (1954) theorized that minority-majority group relations pass through four successive stages: 1) sheer contact, 2) competition, 3) accommodation, and 4) assimilation. In relation to Allport's scheme, it would appear that school integration may contribute to minority assimilation by positively affecting accommodation on the part of Whites. This accommodation may, in turn, lead to a more racially integrated society.

The present study also indicates that school integration is neutral with regard to Non-white attitudes toward societal integration. Non-white preference for living in racially integrated neighborhoods appears unrelated to their school integrated experience as measured in this study. This is not surprising given the fact that Non-White tolerance for the presence of the other race is consistently higher than is the case for whites, 1.e. NonWhites preferred neighborhoods that are 608 White, while Whites prefer nelghborhoods that are 318 Non-White. Given their high preference for racially integrated neighborhoods, school integration would have to excerpt a very powerful Influence to affect a positive change in Non-White attitudes toward residential racial integration. 
The results of this study, when compared to previous surveys of White attitudes toward residential racial integration in Portland, Oregon, Indicate a continuing trend toward Increased acceptance or "accommodation" of Non-Whites by Whites (DeBerry and Agger, 1968; Portland Housing Integration Task Force, 1983). However, Non-Whites may be unable, in many cases, to take advantage of this increased acceptance because of continued disparity in economic status. For example, according to the 1980 census, oregon's Black families had an average household income that was 348 less than the average household income for whites i.e., $\$ 13,469$ v. $\$ 20,210$. Consequently, although whites may be becoming more accommodating toward Non-Whites, Non-Whites may lack the income necessary to move into predominantly White neighborhoods.

\section{SCHOOL INTEGRATION POLICY} AND SOCIETAL INTEGRATION

As suggested earlier, the school integration policy in Portland, oregon has been percelved as necessary in reaching the goal of societal integration. This study confirms the existence of a relationship between school integration experience and attitude toward residential racial integration. Specifically, the onset of school integration experience is positively related to attitude toward housing integration. To this extent, school integration in 
Portland, Oregon can be viewed as being related to attitudes that may contribute to increased societal integration.

During the 1988s, Portland's school integration policy shifted from that of forcing interracial contact at the early grade levels, i.e. creation of Early Child Education Centers and elimination of middle grades in the Black Community, to restoring and maximizing individual choice. This shift in policy has resulted in the resegregation of elementary schools in the Black Community. This resegregation, in turn, reduces the incidence of interracial contact at the early grade levels. The present study Indicates that a reduction in this type of interracial contact will weaken the relationship between school integration and positive attitudes towards societal integration in Portland.

\section{STUDENT ATTITUDE TOWARD RES I DENT I AL RACIAL INTEGRATION AND SUBSEQUENT BEHAVIOR}

The obvious problem with attitudinal studies is the difficulty of assuming a relationship with future behavior. Reviews of the literature, however, indicate that relationships between attitude and behavior are consistent when accurately paired (Ajzen and Fishbein, 1977). This research reveals that behavioral attitudes or attitudes expressed in terms of behavioral acts do, in fact, correspond to subsequent behavior. In this study, the 
survey was designed to measure "behavioral" attitude, e.g. "I would live in a neighborhood block. .." Consequently, the general finding that attitude and actual behavior are related suggests that the attitudes measured in this study will be related to subsequent actions.

Whether or not positive attitude toward residential racial integration will result in increased residential racial integration is another matter. As noted in Chapter Two, factors other than interracial attitude are the primary determinants of residential choice behavior, e.g. proximity to work, dwelling features, and cost. Thus, for racial attitude to have an influence on residential cholce, these other factors would have to be held constant. That is to say, the desired attributes of proximity to work, dwelling features, and cost would have to be avallable in both an integrated and segregated neighborhood in order for preference toward racially integrated nelghborhoods to express itself in residential choice.

The extent to which attitudes measured in this study will remain constant over time is open to speculation. As mentioned earlier, Allport (1954) theorized that minoritymajority relations go through successive developmental stages. This line of thinking postulates that accommodation leads to assimilation. If this is the case, positive attitude toward residential racial integration, 1.e. accommodation on the part of whites, should lead to residential 
racial integration or assimilation in the long run.

on the other hand, Allport (1954:261) warned that the successive stages of minority-majority race relations are not irreversible:

Nor is the sequence irreversible. We know that where accommodation once existed, retrogression to stage of competition and conflict may often occur. Race rlots represent such a throwback, so too do periodic outbreaks against Jews. In Germany, as we have noted, all existing anti-semitic legislation was repealed in 1869 . For the next sixty years, a perlod of peaceful accommodation seemed to have set in. Then, under Hitler, the tide was reversed. The Nurnberg laws and programs exceeded in ferocity any anti-semitism that had ever previously existed in Germany.

Thus, positive attitudes toward racial integration expressed by high school seniors may not persist throughout their adult lives.

Kelman (1961) theorizes that attitude permanence is a function of how the attitude is obtained. he lists three types of attitude acquisition: compliance, identification, and internalization. Compliance occurs when a person adopts an attitude to obtain a reward or favorable reaction. For example, an employee may express a certain attitude in order to please his or her employer. Attitudes of this type are generally expressed only in the presence of a rewarding agent and are short lived. Identification pertains to attitudes derived from groups or persons one is trying to emulate. Thus, a child may adopt the attitudes of his/her parents or peer group. Finally, internalization relates to 
attitudes formed as an extension of values. For example, one may have a negative attitude toward oll companies because he/she values the environment and oil companies create pollution.

Given the finding that the relationship between school integration experience and attitude toward residential racial integration is based on early age interracial contact, it may be postulated that the racial attitudes expressed in this study were mainly of the internalized variety. If these attitudes were compliance or identification acquired, they would not necessarily be related to early age contact. Compliance derived attitudes should be expressed to obtain favorable reaction regardless of past experience. Likewise, racial attitudes obtained through identification should be expressed irrespective of early age contact. On the other hand, attitudes acquired through an internalized value system would be related to early age experiences that tend to shape a person's value system.

In conclusion, it must be remembered that only a small, albeit significant, part of the varlation in attitude toward residential racial integration was accounted for by school integration experience. Consequently, the persistence of racial attitudes Into adult 11 fe and subsequent behavior of student surveyed will be the result of many other factors outside the school integration experience. 
KE'E'RE'NCES

Allport, Gordon w. 1954. The Nature of prejudice. Cambridge, Mass.: Addison Westley.

Ajzen, lcek and fishbein, Martin. 1y77. "Attitude-Behavior Relations: A rneoretical Analysis and Review of timpirical Kesearch." esychological Bulletin. 84(5): $888-918$.

Armor, D.J. 1975. "The Evidence on Busing." The public Interest. 28 (jummer): $98-126$.

Bardsley and Haslacher. 1983. Neighborhood Integration in Portland, Oregon. Portland, Oregon: Portland Housing Integration Task Force.

Bel1, Derrick. 1980. Shades of Brown: New Perspectives on School Desegregation. Columbia University, New York: Teachers College Press.

Blanchard, Hobert $w$. 1978. Superintendent's Response to the Report and Recommendations of the community Coalition tor School Integration. fortland, uregon: Fortland public sehnols.

Bullough, Bonnie. 1969. Social-psychological Barriers to Housing Degegregation. Los Angeles, California: Graduate School of Business Administration, University of California at Los Angeles.

Carithers, M.W. 1970. "School vesegregation and Kacial Cleavage: A Review of the Literature." Journal of social Issues. 26 (4): 25-47.

Citizens' Committee For Hetter schools. 1969. Position Paper. 27 (6): 643-647.

Committee on Race and tucation. 1964. Race and bqual Educational opportunity in Portland's public schools. Portland, oregon: Multnomah County school District No. 1 .

Community Coalition For School Integration. 1978. Equity For the Eighties: A Report to the Board of Education. portland, Oregon: portland Public Schools. 
Cook, stuart W. 1985. "Experlments on soclal Issues: The Case of school Integration." American Esychologist.

$40(4): 452-468$.

Crain, Robert L., Mahard, Kita E., and Narot, Ruth E., 1982. Making Desegregation Work: How schools Create Social Climates. 1982. Cambridge, Mass.: Ballinger Publishing Company.

Darden, Joe T. and parsons, Margaret A. 1981. "The Effect of Neighborhood Racial Composition on Black and white Attitudes," The Urban keview, 13 (2): 103-149.

DeBerry, Clyde and Agger, Robert E. 1968. "School and Race in portland," In Integrated Education: A Reader, Meyer Weinberg, editor. Beverly Hills, California: The Glencoe press.

Editors, Urban Atfairs Quarterly. 1983. "Symposium on race and Resldential segrigation." urban Attairs quarterly. 18 (3): 299 .

Espositio, Dominick. 1973. "Homogeneous and Heterogeneous Ability Grouping." Review of Educational Research.

43 (2): 163-179.

Farley, John E. 1983. "Metropolitan Housing segregation in 1980: The 3t. Louis Case." Urban Affairs Quarterly. $18(3): 347-359$.

Goldstein, Carole G., Koopman, Eilizabeth J., and Goldstein, Harold H. 1979. "Raclal Attludes in Youth Children As a Function of Interracial contact in the public Schools." American Journal of orthopsychiatry. 49 (1): $89-99$.

Gordon, M. 1964. Assimilation in American Life. New York: oxford University Press.

Greeley, Andrew M. 1980. "School Desegregation and Ethnicity," In: school Desegregation: east, eresent, and Future. Stepnan and feasin kids. New York: Flenum Press.

Hallinan, Maureen T. Lyyl. "Ciassroom Racial composition and Children's Friendships." social Forces. $61(1)$ : 56-68.

Hawley, Willis D., Smylie, Mark A., et. al. 1983. Strategles for Effective Desegregation. Lexington, Mass.: Lexington Books. 
Hochschild, Jennifer L. 1984. The New American Dilemma: Liberal Democracy and School Desegregation. New Haven, Conn.: Yale University Press.

Johnson, David A. 1976. "Treating Black students Like White students: A Defintton of school Integration." Urban Education. $11(1)$ : YS-114.

Katz, Michael B. 1971. Class, Bureaucracy and Schools. New York: Praeger Publishers.

Kelman, H.C. 1961. "Erocess of upinion change." Yublic opinion Quarterly. 25:57-78.

Lewis-Beck, Michael S. 1986. Applied Regression. Beverly Hills: Sage Publications.

Longshore, Douglas. 1982. "School Racial Composition and Blacks' Attitudes Toward Desegregation: The Problem of Control in Desegregated schools," Social science quarterly. $\quad 53(4)$ : $674-687$.

Mosteller, Frederick and Moynihan, vaniel P. 1972. on Equality of Educational opportunity. New York: Vintage Books.

Myrdal, Gunnar. 1944. An Amerlcan Dilemma: The Negro problem and Modern Democracy. New York: Harper and Brothers.

National Advisory Commission on Civil Disorders. 1968. Report on Clvil Dlsorders. New York: Bantam Books.

National Education Association. 1968 Apility Groupling Research Summary. Wash., D.C.: National Education Association.

Orfield, Gary. 1978. Must We Bus? Segregated Schools and National Policy. Washington, D.C.: l'he Hrookings Institution.

Orfield, Gary. 1978. "It wishes were Houses the busing Could stop. Demographic rrends and Desegregation Policy." Urban Review. 10 (2): 115-129.

Orfield, Gary. 1980. "School Segregation and Residential segregation" In: school Deseqregation: Past, Present, and Future. Stephan, Walter G. and Feagln,. Joe R. editors. New York: Plenum Press. 
Eatchen, Martin. 1982. Black-whlte Contact in schools: Its social and Academic EEeects. West Lafeyette, Indiana. Indiana Press.

Pearce, Diana M. 1981. "Deciphering the Dynamics of Segregation: The kole of schools in the Housing Cholce Process," The Urban Review. 13 (2): 85-161.

Portland Public Schools. 1980. Comprehenslve Desegregation Plan. Portland, oregon: Portland Public schools.

Portland Public Schools. 1986. 1986 Enrollment Report. Portland, oregon: Portland Public schools.

Prager, Jeffrey, Longshore, Douglas, and seeman, Melvin. 1986. School Desegregation Research: New Directions in situational Analysis. New York. Plenum Press.

Rist, Ray C. 19\%9. Desegreqated ichools: Appraisals of An Amerlcan Experlment. New York: Academic Press.

Rist, Ray C. 1978. The Invisible Children: School Integration in Americian ioclety. (amoridge, Masa.: Harvard University eress.

Rosenberg, Morris. 1968. The Logic of Survey Analyis. New York: Basic Books.

Rossell, Christine H. and Hawley, Willis D. 1983. the Consequences of School Deseqreqation. Pniladelphia. Temple university press.

Rothman, Jack. 1977. Issues in Race and Ethnic Relations. Itasca, Illinois: F.E. Peacock Eublishers.

Schnare, Ann B. 1980. "Trends in Residential segregation by Race." Journal of Urban Economics. I (34): $290-314$.

Secord, Paul E. and Backman, carl w. 1964. jocial Psychology. New York: McGraw-H1ll.

Simmons, Cassandra A. and Brady, Nelvia M. 1981. "The Impact of Ability Group Placement Decisions on the Equality of Educational opportunity in Desegregated Elementary schools," the Urban Review. li (2): 129133 .

st. John, Nancy. 1975. school Desegregation outcomes for Chlldren. New York: John Wiley and Sons. 
Stephan, Walter G., and Feagin, Joe R. 1980. School Deseqreqation: Past, Present, and Future. New York: Planum Press.

Sussman, Michael H. 1984. "Reagan Administration Retreats on School Desegregation." Crisis. y1 (4): 38 .

Taeber, Karl E. 1978. "Demographic Perspectives on Metropolitan school vesegregation." Urban feview. 10 (2): $7 \theta-82$.

Thurstone, L.L. 1929. "I'heory of Attitude Measurement." Psychological Review. 36 (3): 222-241.

U.S. Commission on Clvil Rights. 1967. Racial Isolation in the Public Schools. Volume 1. Washington, D.C. U.S. Government Printing Office.

U.S. Commission on Civil kights. 196\% Racial lsolation in the Public Schools. Volume 2. Washington, D.C. U.S. Government Printing office.

U.S. Commission on Civil kights. 1974. 2'wenty Years Atter Brown. Washington, D.C. U.S. Government Printing Orítice.

U.S. Commission on Civil Kights. 1977. School Integration in Portland, oregon. Washington, D.C. U.S. Government Printing office.

Van Valey, T.L., Roof, W.C., and Wilcox, J.E. 1977. "Trends in Resldential segregation, 1970-1980." American Journal of Soclology. 82: $\$ 26-844$.

We inberg, Meyer. 1970. Desegregation Research An Appraisal. Hloomington, Indiana: Phi Delta Kappa Commission.

Winsberg, Morton D. 1983. "Changing Distribution of the Black Popldation in Florida cities ly. $4-1984 . "$ Urban AEEairs Quarterly. 18 (3): $361-3 \%$. 
APPENDIX A

SENIOR SURVEY 
SENIOR SUTVEY

1. I currently attend schiool.

2. My parent (s) eruduated Srom college. Yes No

3. I have attended the followints schools while I've been a student in the Portland Public school system:

4. My national orifin or race is thite

Non-White

5. On the averape, the racial composition of the classrocons 1 attended was: (circle the $X$ that hest approximates your experience)

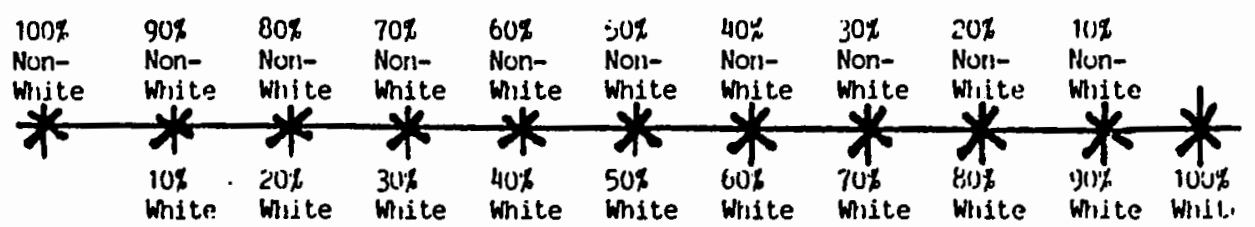

6. Non-Whites and Whites should live in the same nelghtmrhoods-blocks (cirelc one)

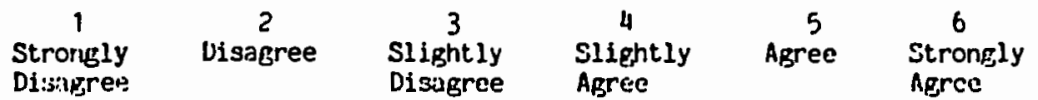

7. I atternded clitssrooms with both Non-White and Wite itudent:s in thic - lollowing gradtes: (circle each prade)

Pre-k.Inderparten, Kinderparten, 1st grade, 2nd grade, 3rd grade, "th grade, 'th grade, 6th grade, 7th grade, 8th grade, 9th gradn, 10 th grade, 11th grade, 12th grade, none 
Pg. 2

B. I participated in extracurricular school activities with both Non-White and white students.

Yes. No

8.a. If yes, list the extracurricular activities (for example: football, track, drama, chess club).

8.b. If yes, on the average, the racial composition of my extracurricular activity groups were:

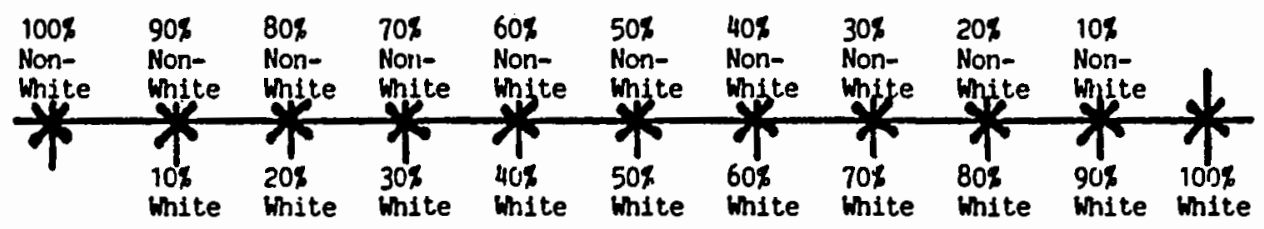

9. Assuming I could live anywhere I wanted to, I would live in a

neighborhood-block that is:

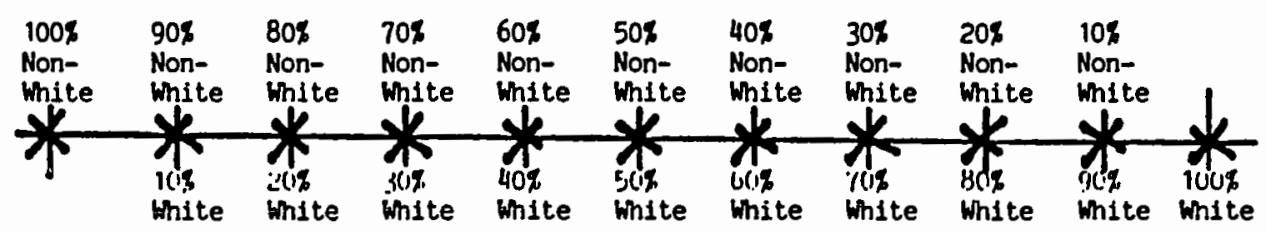

10. I have lived at my current address for years.

10. a. The racial composition of my neighborhood-block is approximately

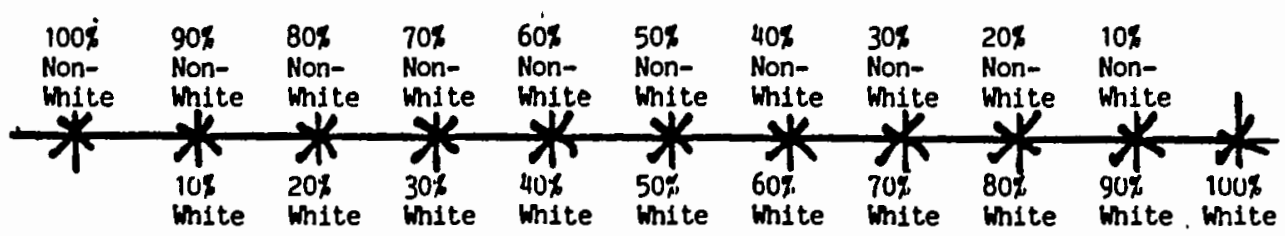


pg. 3

11. After graduating, from high school, I plan on (please check one).

A. Attending a 4 year college or university

B. Atteriding a 2 year college

C. Attending, a vocational or technical training program

D. Working full-time

E. Entering, the military

F. Undecided / Other 


\section{APPENDIX B}

CHRONOLOGY OF DATA COLLECTION 


\section{CHRONOLOGY OF DATA COLLECTION}

It took two years to obtain student attitudinal data for this study. What transpired over the course of those two years is important to note for two reasons. First, it illustrates the process of obtaining student attitudinal data. Second, it accounts for how the sample population was derived for this study.

Portland School District policy 320.23 governs external research. This policy requires interested parties to submit a written proposal describing the scope and significance of their proposed study. PSD reserves the right to reject any proposed study if it does not "focus on matters of high concern and potential usefulness to the District." Consequently, prior to submitting a research proposal, approprlate PPS personnel were quiried about the acceptability of this dissertation study. A generally receptive response was obtained. In addition, certain PPS personnel suggested using the District's Senior survey as a vehicle for obtaining data.

The Senior survey consists of one question regarding future school and/or career plans. From time to time, the district adds additional questions. This was considered to be an excellent mechanism for data collection in that the response rate was approximately 80\%. District personnel were familiar with administering the survey on an annual 
basis i.e., spring, so data collection was thought to be easy and non-disruptive. A survey of high school seniors would provide a sample of students who have been exposed to school integration for the longest period of time 1.e., potentially 12 or more years.

An External Research Proposal was submitted to the Evaluation Department of PPS in December, 1985. The proposal was rviewed by the PPS Evaluation Department and a request for more information was made (See Appendix E for copies of correspondence). Their request for more information was responded to and preliminary approval was obtained by May, 1986.

On July 29, 1986, the Evaluation Department of PPS approved the proposed research based on two conditions. The first condition was that all student data be kept anonymous and confidential. The second condition was that a pilot test of the survey questionnaire be conducted.

The survey questionnaire was pilot tested in November, 1986. The survey instrument proved to be reliable in yielding meaningful results $1 . e .$, out of 85 completed questionnaires only six were incompletely fliled out. Consequently, PPS was convinced that the questionnaire was understandable and would yield reliable information. on January 15, 1987, PPS instructed this investigator to make arrangements for including the proposed survey questions in the 1987 Senior Survey. 
In February, 1987, the PPS personnel in charge of the Senior survey were consulted regarding the inclusion of the dissertation survey in the district's senior survey. The initial meeting was very favorable. District personnel even indicated that PPS would code and tabulate the data on its own computer. However, subsequent to the meeting, this investigator was told over the phone that the person in charge of all the high school counselors was against adding questions the senior survey. Their reasons were: 1) the added questions would make the senior survey too time consuming and, 2) additional questions would reduce the overall response rate thereby jeopardizing the validity of the senior survey. In addition, this investigator was told that the head counselor's position would not be overruled!

An appeal was made to the Evaluation Department to follow-up on its prior approval for including the dissertation questions in the school District's senior survey. This appeal was unsuccessful. However, approval was given to contact each high school principal to obtain permission for conducting a separate survey of their senior class. Letters were imnediately sent out to all high school principals requesting such permission.

The Portland school District has ten high schools. Out of the ten high school principals, three agreed to allow their students to be surveyed, three rejected the request, and four did not respond at all. This created an obvious 
concern about the representativeness of the sample, particularly since the three high schools willing to participate were all in the east part of the school district, leaving the predominantly white west side unrepresented.

Another effort was made to have PPS officials bring about greater participation in the dissertation survey. This effort resulted in a letter being sent to the principals who had not responded to the first inquiry. The investigator focused his energy on accessing a high school on the predominantly white west side of the district. Approval was finally obtained to include an additional high school from the west region of the district in April, 1987. Thus, the sample population for this study was comprised of high school students from four of PPS's ten high schools. 


\section{APPENDIX C}

SENIOR SURVEY INSTRUCTIONS 
Q HXU UF UKAAN ANI) PUBIK AIIAIKS

OFPRIMENT US

URHAN SIUDIES ANI) I'IANNINC

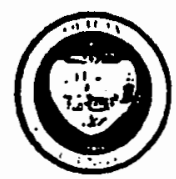

PCIRTLAND

SIAIE

UNIVERSITY

P.S H(IX) 721

IY SRILAND. IREC:ON

$47211:$

(503) 229.4045

SENIOR SURVEY

INSTRUCTIONS

THE ATTACHED SURVEY IS PART OF A DOCTORAL RESEARCH PROJECT

IN URBAN STUDIES. THE RESEARCH IS ABOUT THE RELATIONSHIP BETWEEN

SCHOOL EXPERIENCES NND YOUR ATTITUDES TONARDS LIVING IN A RACIALLY

INTEGRATED NEIGHBORHOOD.

YOU ARE NOT TO PUT YOUR NAME ON THE QUESTIOMNAIRE. THIS IS

HOT A TEST OF ANY KIND. THERE ARE NO RIGHT OR WRONG ANSWERS.

FINALLY, YOU DO NOT HAVE TO FILL OUT THE QUESTIONNAIRE IF YOU DON'T WANT TO. 
APPENDIX D

CORRESPONDENCE WITH SCHOOL DISTRICT 


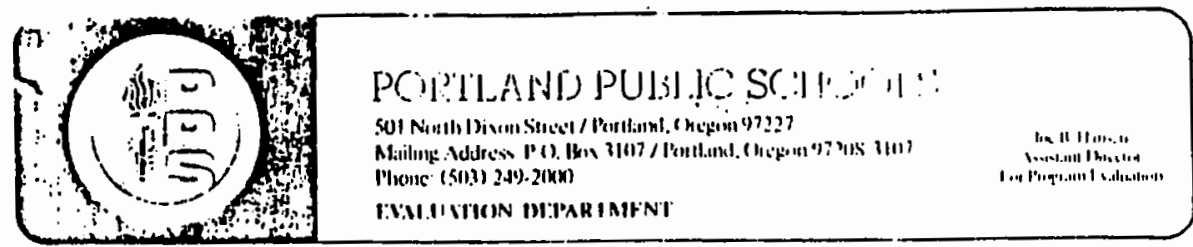

$\operatorname{san} 270$

January 24,1986

Mr. Rocky Johnson

Executive Director

Community Action Team, Inc.

351 Columbia Blud.

St. Irelens, OR 97051

Dear Mr. Johnson:

Your request for permission to conduct a study of the relationship between school integration and neighborhood integration in the Portland Public Schools has been referred to me by Walter llathavay, Director of Research and Evaluation for response. Our departmentol management team has reviewed your proposal and found that we need further information before we can recommend approval. Specifically, we need answers to the following questions:

How will the results of the study be use[ul to Portland Public Schools or to the advancement of education?

How large a student sample will be required and at what grade levels?

- What is the sampling plan, e.g., random, stratilied rhinduin, etc.?

- Who will administer the survey and how? Will this require principal or teacher involvement? If so, how much and in what way?

- Will data be collected from any other school district sources, e.g., teachers, principals, computer files?

For your information, I have enclosed a copy of Portland Public Schools Policy 320.3 concerning the review of external rescarchers' studies. Familiarity with this policy should help you as you formulate answers to these questions.

Once we have received your responses, our management team will act promptly to review and act on them. The Portland Public Schools is always willing to cooperate with researchers engaged in meaningful and significant educarional research. We must, 


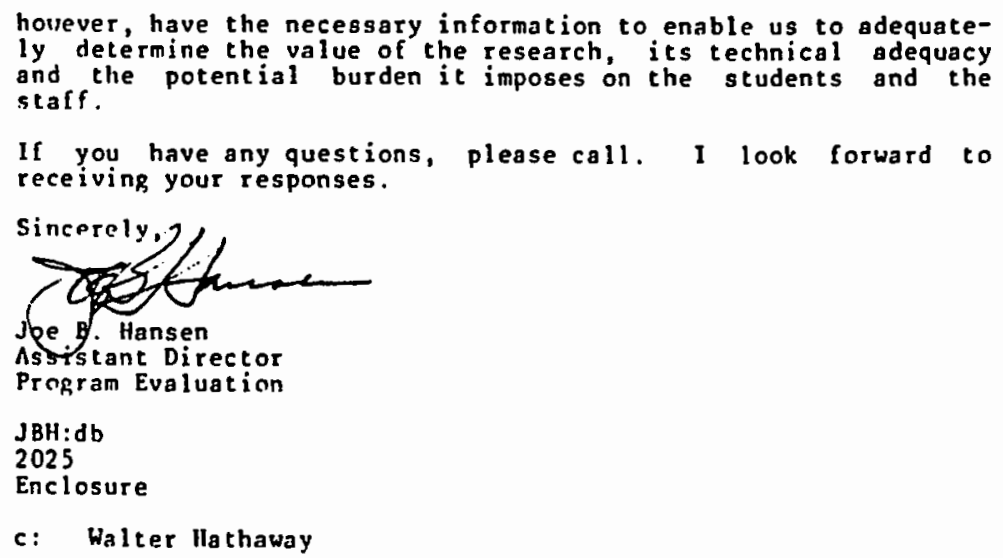

If you have any questions, please call. I look forward to receiving your responses.

sincerely.j,

Jpe B. Hansen

Assistant Director

Program Evaluation

$J B H: d b$

2025

Enclosure

c: Walter llathaway 
rolicits mo nequLATIONg

920.22

Schoot Busdong Adoministestion Sorres 3000 (Iocitefirs and Grounges) REsEAPCK STUDIES - mTERMAL

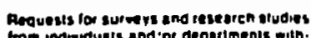

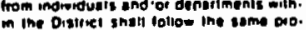

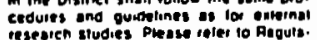

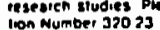

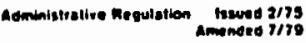

920.29

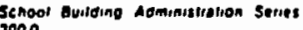

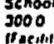
(Caemines and Grouno:

mesEamen studies - ExteAmal

The Portland Schood Dealict einnes to

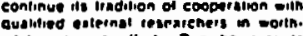

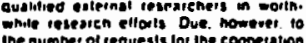
ine number ol requessis lot ing cooperinion ol Distice sludents and glall in iferoureh

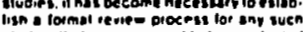
itudins imat ane oroposed lo be conducled below

I cenireaia

The coulerin innt will be uard in the rocul on mantiers ol hugh conceln

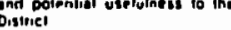
promise of worinumile conimibu. oase los eoucsion

B Oesign

Agequacy of ine conecealual tha. mermoth, the irsegeren querlions. ind ine dals collezilon, dalio. ceoures ADthopusieness und limelines: of pinposso dienpaments 10 ipdort and explam nessults of the coproporste considerolion for ine wonth and ieflings of ine subiocts

Conligenliatity ol miarmalion oest. sill

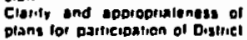
plans lor participal
sluumeris and siall.

$c$ corvenes

crinimum aturuplion ol Distict

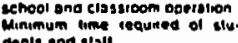

2 paoceounes

Applicants) will present to ine

proposst acseribing inf seone

and sugnticance of the slupy ats

ned use ach onstinution of tim

dete ind Lingings Degulment

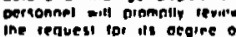

Perismo Puote senoole

gotherence to ine cruetros above

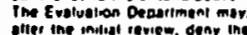
mequest io concuet s. Geny ine its vew. ine ores on ol ine sivor of ins value of ime inlormalion lo be enterise inted above contorm to ina

c Alludy inst mose posire ine Evalualion oe pollinent:

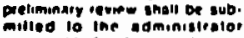
meomiste for the ocosimmenis. involved in the sluder io inis Dominisitusior may drecine 10 o10.

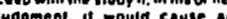

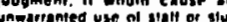
denl lime. of Il ina conduel at the cludy molo cre.te unluwersme ine tuay is apovoyed in win ine invelting nlor to ine fulles? possuble enlent Litremeste. the

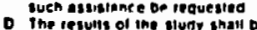

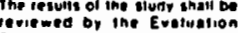
Dapurimeni belore 1 Elepse by the sudoived 10 ithe depaslmen

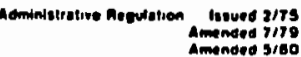

92024

Serool Burieng Aominizisotion Solies (Taesilies und Grounds? MEOUESTS CON INFONMATION a exreanal

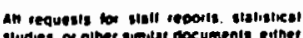

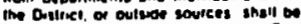

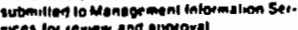

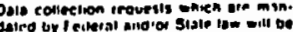

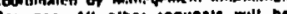

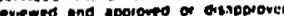
boted on a determmation ol ine calue of mo inlormation iroursiled verives ine chal - contect suen miormation in ina reavar

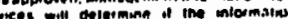

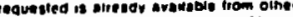
soviters everh al combuler lars on lies of ano hava roconily

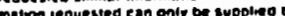

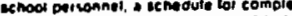
tron of ine renutil eith or miranged to be mulually getisisctiory lo ine requesser ing

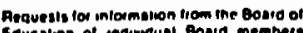
Couearon of inguverual bosid mombers The sugerningnons inlormation Seroures lor an estimale of ine

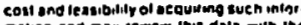

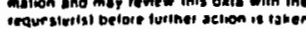
irgur stertig beloriest

Inlormalion requeste inal have benen re.

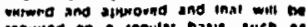

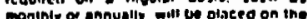
Consolidalen calendar of neporling

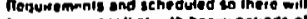

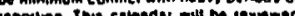
by belose ine meginning ol esech rennot veat

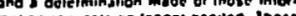
Jul

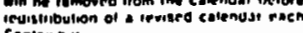
Scalentite

Acomenitumere Regutation Iseured 710 


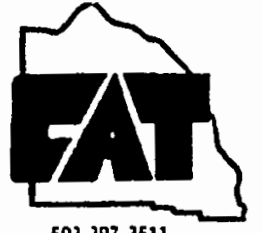

503397.3511

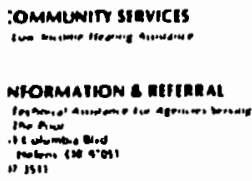

VIATHERIZALON ROCRAM

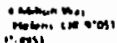

KAD SIANI

and

INIOR servicis

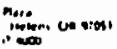

OMMUNITY OIVHORMINI

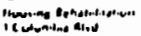

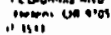

\section{COMMUNITY ACTION TEAM, INC.}

351 Columbia Blyd.

St. Helens, Oregon 97051
Fobruary 13, 1986

Joe B. llansen

Assistant Director, Progran Evaluation

Portland Public Sclools

501 Worth Dixon st.

P.O. Box 3107

Portland, Or. 97208-3107

FE: Response to January 24, 1986 letter regarding proposed rescarch: "The Relationship Between School Integration and Attitudes Toward Residential Integration"

Dear: Mr. Hansen:

As we discussed on the phone, I will foas ny response to your first question i.e.. "how will the results of the stuxly be useful to Portland Public Schools?"

Racial integration of oir public sctools cont Inues to be a gal inspite of the lack of enthusiasm at the federal level. Racial integration of sctools is still a goal of the rortland Public School District. Given this reality, it scoms obvious that educators and community leaders would be interested in the relationship between school integration and attitudes toward residential integration. $n$ better understanding of this relationsilip will help maximize the potential of the school integration experience to foster as integrated socicty i.e., residential integration. An integrated society would eliminate the need for school districts to spend an Inordinate omount of resources to bring about racial integration in the schools.

is I indicated to you both in siry written proposal and over the phone, I would like to use the aunual "Senior Survey" as my veluicle for obtaining data. This should answer questions two through four. 
page 2

Finally, I do not intend to gather primary data from any other school district.

Thank you for your tine and interest in my research. I look forward to learing from you soon.

$$
\begin{aligned}
& \text { Sincerely, } \\
& \text { Rocky Johrson, } \\
& \text { Diecutive Director }
\end{aligned}
$$

ce Bill soott 


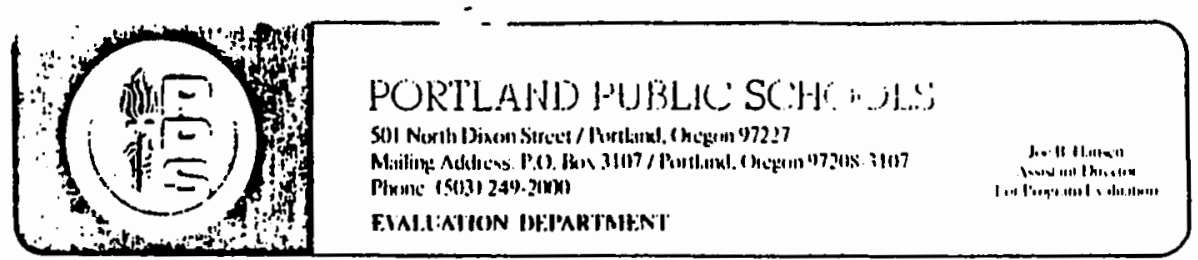

May 8,1986

Rocky Johnson, Executive Director

Community Action Team, Inc.

351 Col umbia Blud.

st. Helens, oregon 97051

Dear Rocky:

As I promised in our telephone conversation this morning, here is the response of our Research, Evaluation and Testing Department 's management team to your proposed questionnalre to be appended to the Senior Survey.

We found the questions $(7,8$ and 9$)$ dealing with bigotry, rigidity and conservatism to be objectionable and unsultable for use with a school population. unfortunately we cannot approve their use. We are concerned about the possible inflammatory and divisive effect such items may have on the respondents. We are further concerned that items such as these would arouse a negative public reactlon against which we would have no reasonable defense. We found the rationale for these items to be weak and could not link them satisfactorily to the original research proposal enclosed with your letter of December $6 \mathrm{th}, 1985$

We would like to see a draft of your survey pilot tested on some other population before it is used in the portland schools. Such a pilot test would enable you to revise any items that are not yielding the data you need to answer your key research questions.

Since it is alresdy too late to Include this questionnalre in the Senior survey for the 1986 graduating class, we suggest that you make the suggested change, pllot test and revise the instrument as needed and plan to administer it in the spring of 1987.

we wish you success in your research efforts and remain ready to assist you, provided that the above stated concerns can be dealt with satisfactorily.

sincerely.

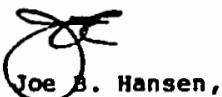

Assistant Director

cc: Walter Hathaway

Dean Forbes

Ron Houser 


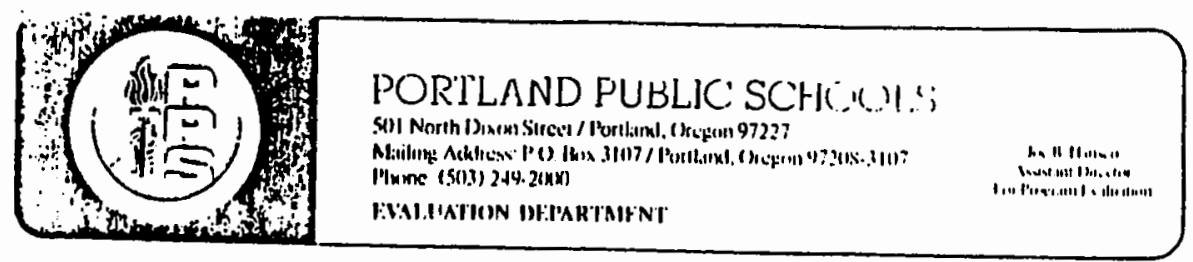

July 29,1986

Mr. Rocky Johnson, Execut Ive Director

Community Action Team, Inc.

351 Columbia Blud.

St. Helens, oregon 97051

Dear Rocky.

The Research and Evaluation Department management team has reviewed the revised questionnaire you submitted for inclusion with the 1987 senlor survey and has approved it for use, contingent upon the following conditions.

1. All student data must be kept anonymous and confidential.

2. A pilot test of the questionnaire will be conducted with a volunteer group of juniors this fall.

You have our permission to contact High School principals to seek a suitable group for a pilot test. Please keep this office informed of your progress.

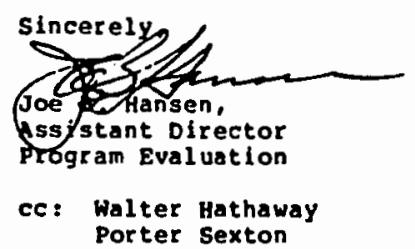




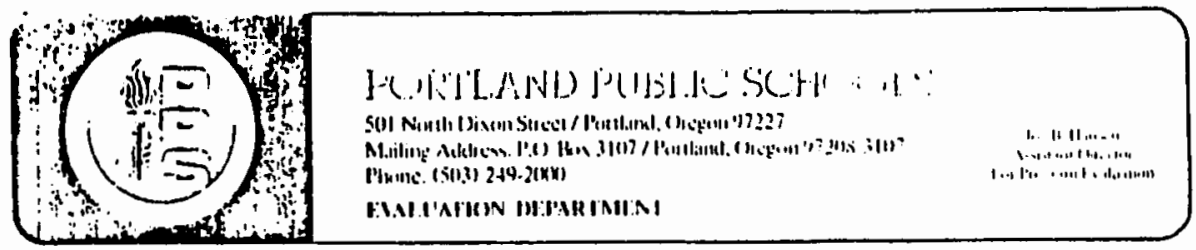

January 15,1987

Mr. Rocky Johnson, Director

Community Action Tream, Inc.

351 Columbis Blud.

St. Helens, OH 97051

Dear Rocky,

Thani. you for the letter updating us on the progress you have made with your integration survey. I'm pleaser to henr that Dr. Rose and her staff were helplul. As you know, Porter Sexton has responsibility for the Senior Survey, therefore you should contact him to arrange to have your questionnaice includerl with that survey. Please continue to keep us informed of your progresis.

sincerely

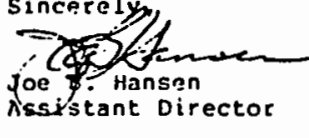

cc: Porter Sexton Walter Hathaway 


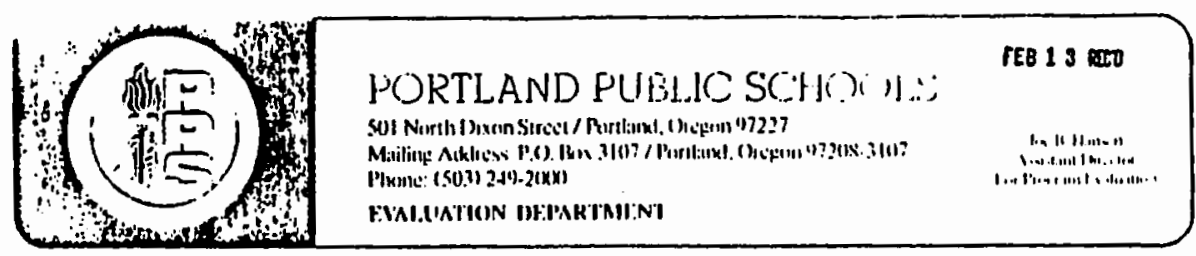

fouruary 12,1937

Mr. Rocky Johnson, Executive Director

Coninunity Action Jeain, lnc.

351 Columbia Blud.

St. Helens, Orenon 97051

Dear Rocky,

The kesearch and Evaluation Departinent managenent teain is pleased to hear that you have successfully coinpleted the pilot testing, at Grant Hiqh school, of your survey on attituides toward neighborhood integration. We have thoroughly revieved your survey anj approved it for use, contingent upon the success of the pilot study and with the further stipulation that all sturient rata inust be kept anonymous and confidential.

You have our permission to contact High School peincipals to seek their voluntary participation in your study. Please kenp us informesi of your progreis.

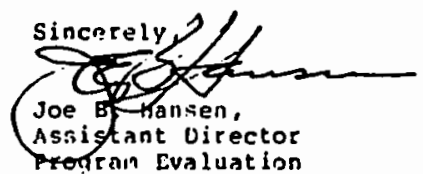

cc: halter Hathaway

Porter Sexton 


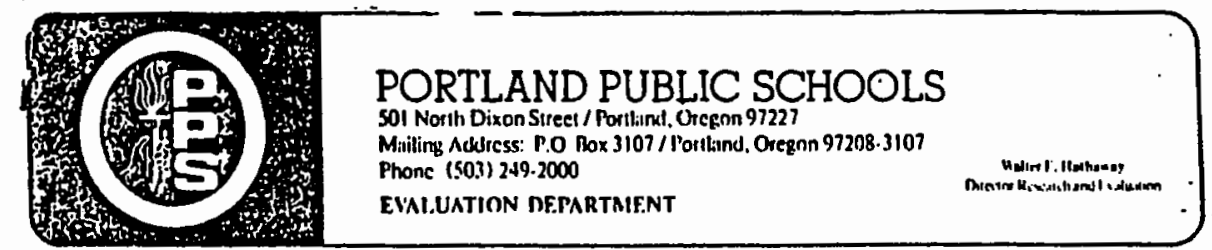

April 7,1987

MEMORANDUM

TO:

Judy Lachenmeier

Principal Lincoln High

FR:

Walter Hathaway wH

You were recently contacted in writing by Mr. Rocky Johnson, Executive Director of The Community Action Team, inviting you to particlpate in a district approved research study on The Relationship Between school integration and student attitudes Toward Residential Integration. iplease see attached correspondence.) Mr. Johnson will be calling you soon to see whether you are willing to cooperate in surveying your seniors with the attached instrument. Thus far, three of our high schools have agreed to particlpate.

As you prepare to respond to Mr. Johnson's request, please be aware that the Superintendent and members of the Board are interested in seeing that we obtain a representative sample of responses to this study which promises to provide the district information of use in evaluating and planning our district decision to participate in this study or not remains yours, this is one that we believe deserves your careful evaluation.

Thank you for your consideration.

WH: $d b$

Attachment 
APRENDIX E

RAW DATA 
DATA I.ISI FREE; SCHI PTB RA CRC CA OSI YSI EA HEA ERC BA YHI IIRE CP. BETIII TIATA.

$\begin{array}{lllllllllllllll}35 & 1 & 1 & 5 & 5 & 1 & 3 & 13 & 1 & 2 & 1 & 3 & 1 & 3 & 0\end{array}$

$\begin{array}{lllllllllllllll}35 & 0 & 1 & 2 & 4 & 12 & 12 & 1 & 1 & 3 & 1 & 17 & 1 & 1\end{array}$

$35008+141411563440$

3511461414144235621

$\begin{array}{llllllllllllll}35 & 1 & 1 & 3 & 5 & 13 & 13 & 1 & 1 & 2 & 6 & 9 & 2 & 1\end{array}$

3501551412651321

3501451313111231.40

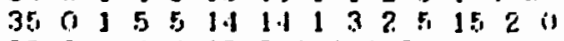

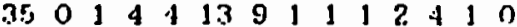

$\begin{array}{llllllllllllll}35 & 0 & 1 & 5 & 6 & 13 & 13 & 1 & 2 & 2 & 6 & 6 & 2 & 0\end{array}$

$350076 \begin{array}{llllllllllll}35 & 0 & 7 & 6 & 13 & 1 & 2 & 6 & B & 14 & 11 & 0\end{array}$

$\begin{array}{llllllllllllll}35 & 1 & 0 & 7 & 5 & 14 & 13 & 1 & 1 & 5 & 8 & 9 & 9 & 1\end{array}$

3511376011141116601041

$\begin{array}{llllllllllllllll}35 & 0 & 1 & 5 & 5 & 1.3 & 13 & 1 & 2 & 3 & 2 & 13 & 4 & 0\end{array}$

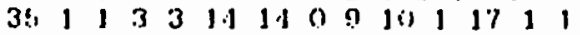

3! 11446 1\% 12 j i 3 ; 122

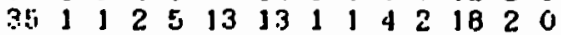

$\begin{array}{llllllllllllll}35 & 0 & 1 & 5 & 6 & 14 & 13 & 1 & 1 & 2 & 6 & 11 & 2 & 0\end{array}$

$\begin{array}{llllllllllllll}35 & 0 & 1 & 4 & 6 & 13 & 13 & 1 & 2 & 3 & 3 & 13 & 1 & 1\end{array}$

$\begin{array}{llllllllllllll}35 & \ddots & 1 & 6 & 5 & B & 8 & 9 & 9 & 11 & 6 & 7 & 10 & 0\end{array}$

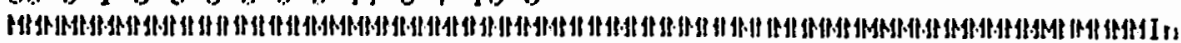
sciliningte.

3501665889991167100

$\begin{array}{lllllllllllllll}35 & 1 & 1 & 2 & 3 & 6 & 8 & 9 & 9 & 11 & 2 & 17 & 1 & 0\end{array}$

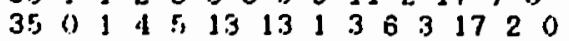

$\begin{array}{llllllllllllll}35 & 1 & 0 & 10 & 3 & 14 & 101 & 1 & 9 & 9 & 12 & 10 & 1\end{array}$

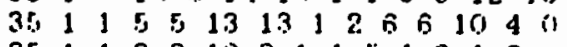

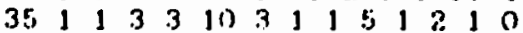

$\begin{array}{lllllllllllll}35 & 1 & 3 & 9 & 6 & 1 & 2 & 5 & 6 & 2 & 0\end{array}$

3! $014+13121442920$

$\begin{array}{lllllllllllllll}35 & 1 & 1 & 4 & 4 & 12 & 12 & 1 & 3 & 4 & 4 & 17 & 1 & 1\end{array}$

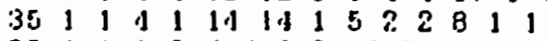

3511134409102360

$\begin{array}{lllllllllllllll}35 & 0 & 1 & 3 & 4 & 13 & 13 & 1 & 2 & 3 & 2 & 15 & 2 & 0\end{array}$

$\begin{array}{llllllllllllllll}35 & 0 & 1 & 5 & 3 & 13 & 13 & 1 & 1 & 6 & 4 & 15 & 2 & 0\end{array}$

$\begin{array}{lllllllllllllll}35 & 1 & 1 & 3 & 1 & 1 & 1 & 1.1 & 1 & 1 & 2 & 1 & 1 B & 1 & 0\end{array}$

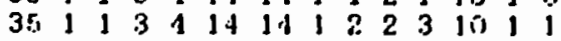

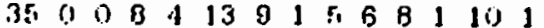

$\begin{array}{lllllllllllllll}35 & 0 & 1 & 2 & 3 & 13 & 10 & 1 & 2 & 3 & 1 & 15 & 2 & 0\end{array}$

$\begin{array}{lllllllllllllllll}35 & 1 & 1 & 3 & 5 & 13 & 13 & 1 & 4 & 4 & 3 & 13 & 1 & 1\end{array}$

$\begin{array}{llllllllllllll}35 & 0 & 1 & 2 & 5 & 12 & 11 & 1 & 2 & 6 & 2 & 1 B & 1 & 0\end{array}$

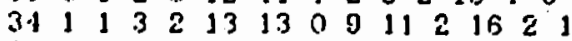

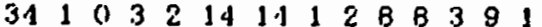

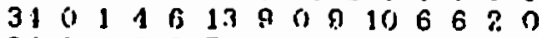

3401653760145251511

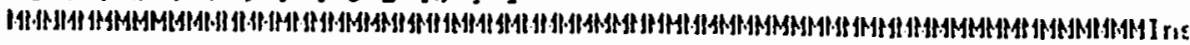

Bellinst $2 . r$ 
$\begin{array}{llllllllllllll}34 & 1 & 1 & 3 & 5 & 12 & 9 & 1 & 1 & 6 & 6 & 10 & 2 & 1\end{array}$

$3411226 \begin{array}{lllllllll} & 1 & 9 & 1 & 2 & 3 & 4 & 2 & 1\end{array}$

$\begin{array}{llllllllllllll}34 & 1 & 1 & 2 & 5 & 14 & 14 & 1 & 4 & 6 & 4 & 10 & 4 & 1\end{array}$

$\begin{array}{llllllllllllll}34 & 1 & 1 & 2 & 3 & 7 & 7 & 1 & 3 & 3 & 2 & 18 & 2 & 1\end{array}$

$\begin{array}{llllllllllllll}34 & 0 & 0 & 9 & 6 & 11 & 11 & 1 & 2 & 5 & 8 & 1 & 7 & 0\end{array}$

$\begin{array}{lllllllllllllll}34 & 1 & 0 & 8 & 6 & 14 & 14 & 1 & 9 & 6 & 6 & 17 & 9 & 0\end{array}$

$\begin{array}{llllllllllllll}34 & 1 & 1 & 4 & 6 & 14 & 14 & 1 & 1 & 2 & 4 & 1 & 2 & 1\end{array}$

$\begin{array}{llllllllllllll}34 & 1 & 1 & 2 & 6 & 13 & 13 & 1 & 6 & 2 & 5 & 12 & 4 & 1\end{array}$

$\begin{array}{llllllllllllll}34 & 1 & 1 & 2 & 5 & 13 & 13 & 1 & 2 & 2 & 3 & 18 & 1 & 1\end{array}$

$\begin{array}{lllllllllllllll}34 & 1 & 1 & 5 & 6 & 14 & 14 & 1 & 4 & 6 & 6 & 17 & 8 & 1\end{array}$

$\begin{array}{llllllllllllll}34 & 1 & 1 & 3 & 5 & 14 & 12 & 1 & 2 & 6 & 4 & 10 & 3 & 1\end{array}$

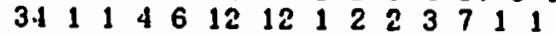

$\begin{array}{llllllllllllll}34 & 1 & 1 & 4 & 3 & 14 & 14 & 1 & 3 & 5 & 1 & 17 & 2 & 1\end{array}$

$\begin{array}{llllllllllllll}34 & 1 & 0 & 9 & 5 & 14 & 14 & 1 & 2 & 8 & 3 & 11 & 7 & 1\end{array}$

$\begin{array}{lllllllllllllll}34 & 0 & 1 & 2 & 5 & 14 & 14 & 1 & 4 & 4 & 4 & 16 & 1 & 1\end{array}$

$\begin{array}{lllllllllllllllllllll}34 & 0 & 0 & 9 & 5 & 13 & 13 & 1 & 3 & 11 & 7 & 10 & 3 & 0\end{array}$

$\begin{array}{llllllllllllll}34 & 1 & 1 & 2 & 5 & 13 & 13 & 1 & 4 & 2 & 3 & 15 & 1 & 1\end{array}$

$\begin{array}{llllllllllllll}34 & 0 & 1 & 5 & 6 & 14 & 12 & 1 & 4 & 6 & 6 & 4 & 2 & 1\end{array}$

$\begin{array}{lllllllllllllll}34 & 1 & 1 & 1 & 5 & 0 & 0 & 1 & 1 & 0 & 1 & 12 & 1 & 1\end{array}$

34 1146141513366142

$\begin{array}{llllllllllllll}34 & 1 & 1 & 4 & 6 & 14 & 13 & 1 & 4 & 2 & 6 & 15 & 2 & 1\end{array}$

$\begin{array}{lllllllllllllll}34 & 1 & 1 & 4 & 4 & 14 & 14 & 1 & 2 & 1 & 9 & 8 & 2 & 1\end{array}$

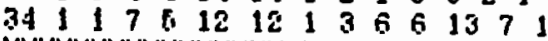

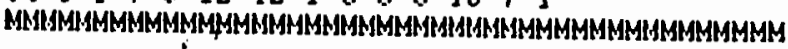




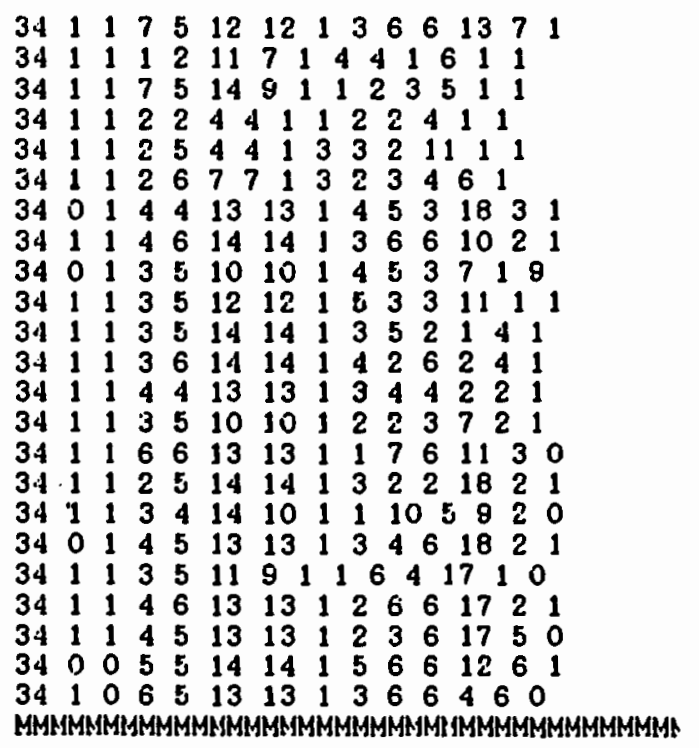

$\begin{array}{llllllllllllll}34 & 1 & 0 & 6 & 5 & 13 & 13 & 1 & 3 & 6 & 6 & 4 & 6 & 0\end{array}$

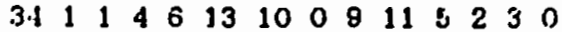

$\begin{array}{llllllllllllll}34 & 1 & 1 & 3 & 5 & 1 & 1 & 1 & 2 & 2 & 3 & 1 & 1 & 1\end{array}$

$\begin{array}{llllllllllllllll}34 & 1 & 1 & 4 & 5 & 14 & 14 & 1 & 2 & 8 & 6 & 8 & 1 & 0\end{array}$

$\begin{array}{llllllllllllll}34 & 0 & 1 & 3 & 5 & 13 & 13 & 1 & 2 & 5 & 6 & 3 & 4 & 0\end{array}$

34008028000901187791

$\begin{array}{llllllllllllll}34 & 0 & 0 & 8 & 4 & 8 & 8 & 1 & 3 & 6 & 6 & 10 & 6 & 1\end{array}$

$\begin{array}{llllllllllllll}34 & 1 & 1 & 3 & 6 & 12 & 12 & 1 & 1 & 6 & 4 & 3 & 3 & 1\end{array}$

34008566009911897101

$\begin{array}{llllllllllllll}34 & 1 & 0 & 8 & 5 & 13 & 13 & 1 & 4 & 6 & 6 & 1 & 9 & 1\end{array}$

$\begin{array}{llllllllllllll}34 & 0 & 0 & 7 & 4 & 12 & 11 & 1 & 3 & 7 & 6 & 9 & 5 & 0\end{array}$

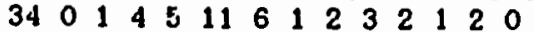

341113361414141254720

$\begin{array}{llllllllllllllll}34 & 1 & 1 & 5 & 3 & 7 & 7 & 1 & 1 & 2 & 3 & 14 & 2 & 0\end{array}$

$\begin{array}{llllllllllllll}34 & 0 & 1 & 5 & 6 & 13 & 13 & 0 & 9 & 11 & 6 & 1 & 2 & 0\end{array}$

$\begin{array}{lllllllllllllll}34 & 1 & 1 & 5 & 5 & 14 & 14 & 1 & 1 & 3 & 6 & 13 & 4 & 1\end{array}$

$\begin{array}{llllllllllllll}34 & 0 & 0 & 10 & 3 & 10 & 9 & 1 & 2 & 10 & 5 & 1 & 10 & 0\end{array}$

$\begin{array}{lllllllllllllll}34 & 1 & 1 & 4 & 1 & 14 & 14 & 5 & 5 & 5 & 1 & 12 & 2 & 0\end{array}$

$\begin{array}{lllllllllllllll}34 & 1 & 0 & 8 & 4 & 14 & 14 & 1 & 2 & 6 & 6 & 9 & 8 & 1\end{array}$

$\begin{array}{llllllllllllll}34 & 1 & 1 & 3 & 4 & 14 & 14 & 1 & 2 & 2 & 2 & 17 & 1 & 0\end{array}$

$\begin{array}{llllllllllllll}34 & 1 & 0 & 7 & 5 & 13 & 8 & 1 & 1 & 10 & 6 & 2 & 8 & 0\end{array}$

$\begin{array}{llllllllllllllll}34 & 0 & 1 & 4 & 5 & 13 & 12 & 1 & 2 & 2 & 6 & 15 & 2 & 0\end{array}$

$\begin{array}{llllllllllllllll}34 & 0 & 1 & 5 & 3 & 14 & 14 & 1 & 2 & 3 & 1 & 1 & 2 & 0\end{array}$

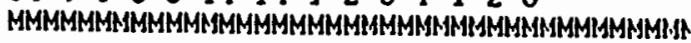




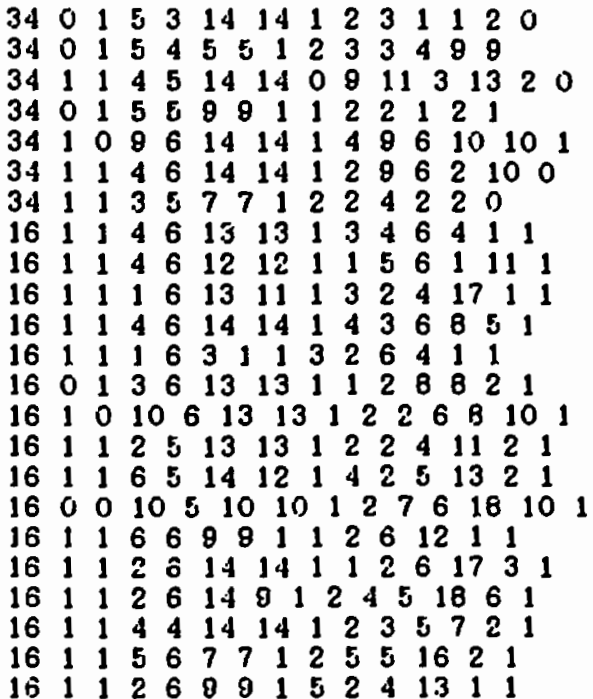

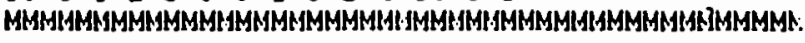

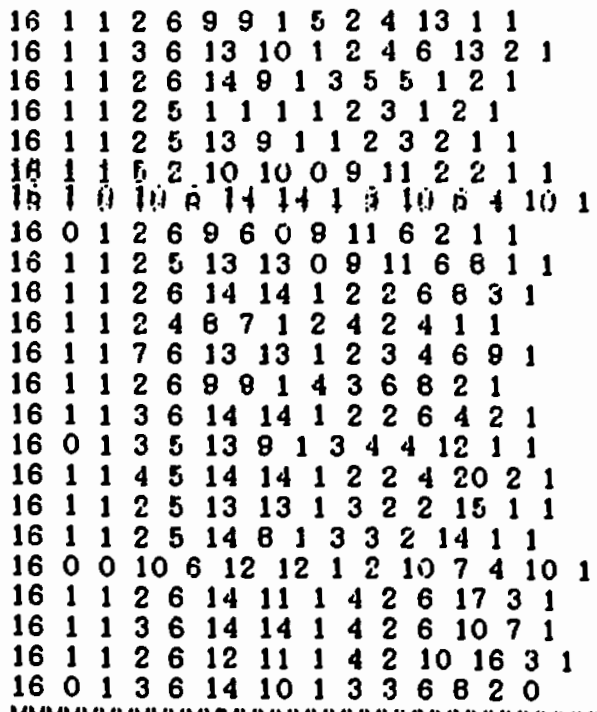

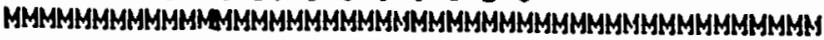




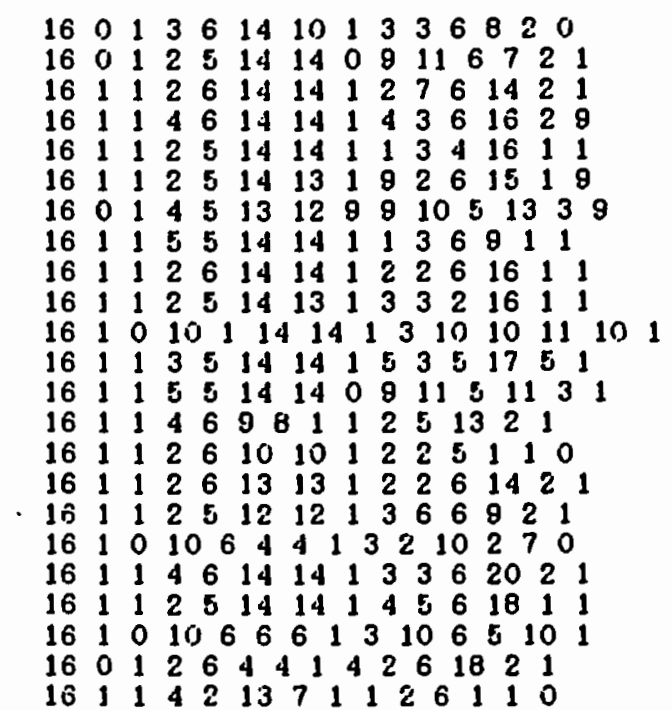




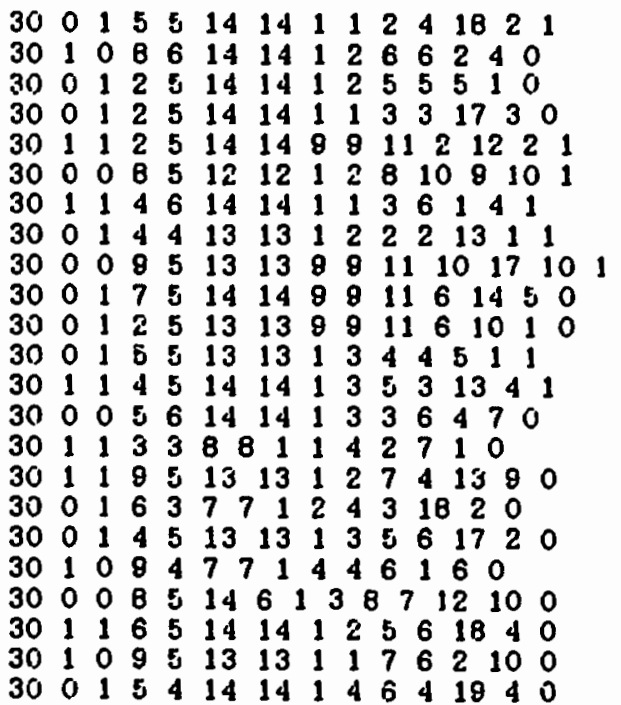

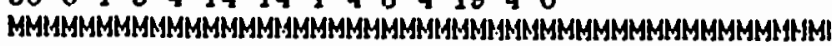

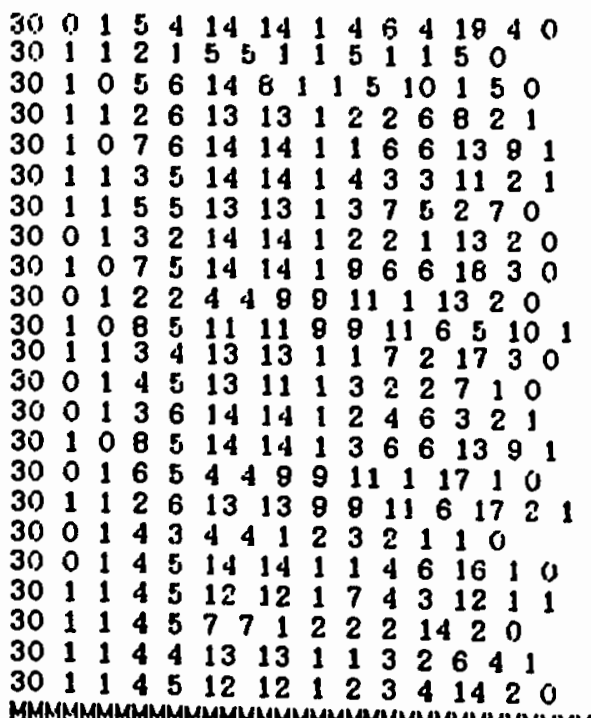

MMNIMMMIMMMUYYHYMMMMHYMHMM 20 
3011445121212341420

$\begin{array}{llllllllllllllll}30 & 0 & 1 & 3 & 5 & 13 & 13 & 8 & 9 & 11 & 2 & 15 & 6 & 0\end{array}$

$\begin{array}{llllllllllllll}30 & 0 & 1 & 2 & 5 & 7 & 7 & 1 & 3 & 2 & 2 & 17 & 1 & 1\end{array}$

$\begin{array}{llllllllllllll}30 & 1 & 1 & 5 & 5 & 13 & 13 & 1 & 1 & 4 & 4 & 16 & 2 & 0\end{array}$

$\begin{array}{llllllllllllll}30 & 1 & 1 & 3 & 5 & 6 & 5 & 1 & 1 & 6 & 2 & 4 & 1 & 0\end{array}$

$\begin{array}{llllllllllllll}30 & 1 & 1 & 4 & 4 & 13 & 13 & 9 & 8 & 11 & 2 & 16 & 1 & 1\end{array}$

$\begin{array}{llllllllllllll}30 & 9 & 1 & 2 & 2 & 14 & 14 & 1 & 2 & 4 & 1 & 18 & 1 & 0\end{array}$

$\begin{array}{llllllllllllll}30 & 0 & 1 & 5 & 5 & 13 & 13 & 1 & 4 & 8 & 6 & 2 & 4 & 0\end{array}$

$\begin{array}{llllllllllllll}30 & 0 & 1 & 3 & 2 & 8 & 8 & 1 & 3 & 6 & 5 & 15 & 2 & 0\end{array}$

$\begin{array}{lllllllllllllll}30 & 0 & 1 & 4 & 5 & 14 & 14 & 1 & 3 & 4 & 3 & 8 & 2 & 0\end{array}$

$\begin{array}{lllllllllllllll}30 & 0 & 1 & 6 & 6 & 14 & 13 & 9 & 9 & 11 & 6 & 8 & 7 & 0\end{array}$

$\begin{array}{llllllllllllll}30 & 1 & 1 & 3 & 1 & 5 & 5 & 1 & 1 & 2 & 1 & 7 & 1 & 1\end{array}$

$\begin{array}{llllllllllllll}30 & 1 & 1 & 4 & 4 & 4 & 4 & 1 & 1 & 4 & 1 & 3 & 2 & 0\end{array}$

$\begin{array}{llllllllllllll}30 & 0 & 1 & 2 & 4 & 14 & 14 & 8 & 8 & 11 & 2 & 18 & 2 & 1\end{array}$

$\begin{array}{llllllllllllll}30 & 0 & 1 & 3 & 5 & 13 & 8 & 1 & 4 & 2 & 6 & 15 & 3 & 1\end{array}$

$\begin{array}{llllllllllllll}30 & 3 & 1 & 6 & 1 & 12 & 12 & 1 & 1 & 10 & 1 & 7 & 4 & 0\end{array}$

301114444881124421

$\begin{array}{lllllllllllllll}30 & 0 & 1 & 3 & 5 & 5 & 5 & 1 & 2 & 6 & 3 & 2 & 10 & 0\end{array}$

$\begin{array}{llllllllllllll}30 & 1 & 1 & 2 & 5 & 12 & 12 & 1 & 2 & 8 & 8 & 7 & 6 & 1\end{array}$

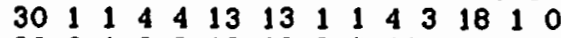

$\begin{array}{llllllllllllll}30 & 0 & 1 & 2 & 3 & 13 & 12 & 8 & 9 & 11 & 1 & 10 & 1 & 0\end{array}$

$\begin{array}{llllllllllllll}30 & 0 & 0 & 8 & 5 & 13 & 13 & 1 & 1 & 2 & 10 & 18 & 2 & 0\end{array}$

$\begin{array}{llllllllllllll}30 & 1 & 1 & 3 & 5 & 10 & 8 & 9 & 9 & 1 & 1 & 3 & 10 & 2\end{array}$

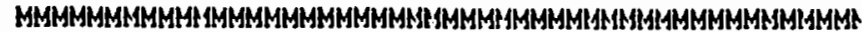

$\begin{array}{lllllllllllllll}30 & 1 & 1 & 3 & 5 & 10 & 8 & 9 & 8 & 11 & 3 & 10 & 2 & 0\end{array}$

$\begin{array}{lllllllllllllll}30 & 0 & 1 & 6 & 6 & 12 & 12 & 1 & 1 & 3 & 6 & 9 & 4 & 0\end{array}$ $\begin{array}{llllllllllllll}30 & 0 & 0 & 7 & 2 & 13 & 12 & 1 & 2 & 9 & 8 & 7 & 10 & 10\end{array}$

$\begin{array}{llllllllllllll}30 & 0 & 0 & 2 & 5 & 4 & 4 & 1 & 1 & 7 & 6 & 2 & 2 & 1\end{array}$

$\begin{array}{llllllllllllllllllllllll}30 & 1 & 1 & 5 & 2 & 3 & 3 & 1 & 4 & 2 & 2 & 2 & 1 & 0\end{array}$

$\begin{array}{llllllllllllllll}30 & 1 & 0 & 9 & 5 & 14 & 14 & 1 & 1 & 5 & 6 & 1 & 6 & 0\end{array}$

$\begin{array}{llllllllllllll}30 & 1 & 0 & 6 & 2 & 9 & 9 & 1 & 5 & 6 & 10 & 3 & 6 & 0\end{array}$

$\begin{array}{lllllllllllllll}30 & 0 & 0 & 8 & 5 & 13 & 12 & 9 & 9 & 11 & 8 & 8 & 10 & 0\end{array}$

$\begin{array}{llllllllllllllll}30 & 0 & 1 & 4 & 4 & 14 & 14 & 1 & 3 & 4 & 3 & 1 & 2 & 0\end{array}$

$\begin{array}{llllllllllllll}30 & 0 & 1 & 7 & 5 & 12 & 12 & 9 & 8 & 11 & 4 & 10 & 8 & 0\end{array}$

$\begin{array}{llllllllllllll}30 & 1 & 1 & 4 & 6 & 14 & 14 & 1 & 3 & 4 & 3 & 7 & 2 & 0\end{array}$

$\begin{array}{lllllllllllllll}30 & 1 & 1 & 5 & 5 & 14 & 14 & 1 & 3 & 6 & 3 & 13 & 1 & 0\end{array}$

30 $111334777 \begin{array}{llllllll}3 & 1 & 3 & 4 & 2 & 18 & 2 & 1\end{array}$

$\begin{array}{lllllllllllllll}30 & 0 & 1 & 4 & 4 & 4 & 1 & 1 & 5 & 6 & 1 & 7 & 2 & 0\end{array}$

$\begin{array}{lllllllllllllll}30 & 0 & 0 & 6 & 5 & 12 & 12 & 1 & 1 & 10 & 8 & 4 & 2 & 1\end{array}$

$\begin{array}{lllllllllllllll}30 & 1 & 1 & 3 & 5 & 14 & 14 & 1 & 4 & 3 & 5 & 17 & 10 & 1\end{array}$

$\begin{array}{lllllllllllllll}30 & 0 & 1 & 6 & 5 & 14 & 14 & 1 & 1 & 6 & 5 & 18 & 4 & 0\end{array}$

30001134414149891112221

$\begin{array}{llllllllllllll}30 & 1 & 1 & 3 & 5 & 13 & 13 & 1 & 1 & 5 & 5 & 18 & 3 & 1\end{array}$

$\begin{array}{lllllllllllllll}30 & 0 & 1 & 7 & 4 & 13 & 13 & 8 & 9 & 11 & 3 & 18 & 0 & 0\end{array}$

$\begin{array}{llllllllllllll}30 & 1 & 0 & 8 & 6 & 0 & 1 & 1 & 2 & 5 & 6 & 8 & 7 & 0\end{array}$

$\begin{array}{llllllllllllll}30 & 1 & 0 & 9 & 5 & 14 & 14 & 1 & 2 & 11 & 3 & 11 & 5 & 1\end{array}$

$\begin{array}{llllllllllllllll}30 & 1 & 1 & 3 & 4 & 14 & 14 & 1 & 5 & 2 & 1 & 2 & 1\end{array}$

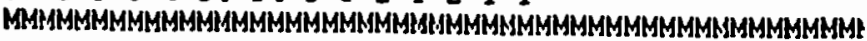




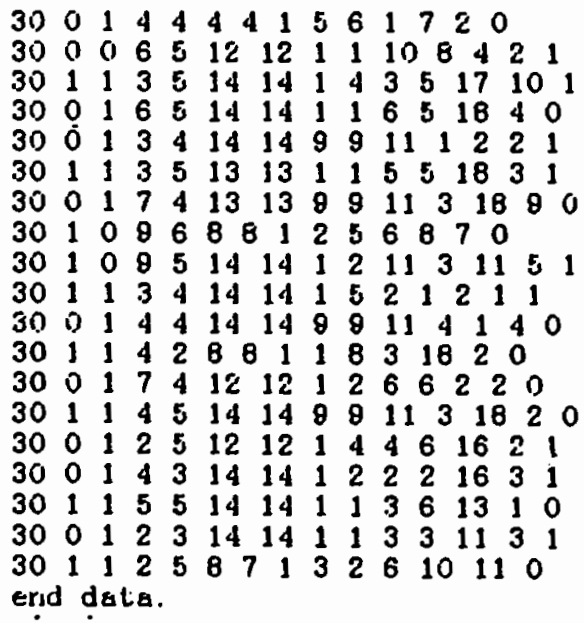

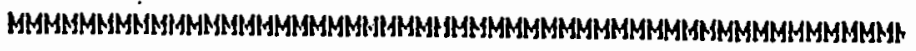

